\title{
11. SITE 456: EAST SIDE OF THE MARIANA TROUGH ${ }^{1}$
}

\author{
Shipboard Scientific Party ${ }^{2}$
}

\section{HOLE 456}

Date occupied: 12 April 1978

Date departed: 13 April 1978

Time on hole: 40 hours 48 minutes

Position: $17^{\circ} 54.68^{\prime} \mathrm{N} ; 145^{\circ} 10.77^{\prime} \mathrm{E}$

Water depth (sea level; corrected m, echo-sounding): 3586

Water depth (rig floor; corrected m, echo-sounding): 3596

Bottom felt (m, drill pipe): 3600.5

Penetration (m): 169

Number of holes: 1 of 2

Number of cores: 19

Total length of cored section $(\mathrm{m}): 169.0$

Total core recovered $(\mathrm{m}): 32.23$

Core recovery $(\%): 19.0$

Oldest sediment cored:*

Depth sub-bottom (m): 114

Nature: vitric mudstone

Age: early Pleistocene (1.6-1.8 m.y.)

Measured velocity $(\mathrm{km} / \mathrm{s}): 1.85$

Basement:

Depth sub-bottom (m): 134

Nature: altered aphyric pillow basalt

Velocity range $(\mathrm{km} / \mathrm{s}): 3.4-4.3$

\section{HOLE 456A}

Date occupied: 14 April 1978

Date departed: 16 April 1978

Time on hole: 51 hours 12 minutes

Position: $17^{\circ} 54.71^{\prime} \mathrm{N} ; 145^{\circ} 10.88^{\prime} \mathrm{E}$

Water depth (sea level; corrected m, echo-sounding): 3586

Water depth (rig floor; corrected m, echo-sounding): 3596

Bottom felt (m, drill pipe): 3601.0

Penetration (m): 159.0

\footnotetext{
1 Initial Reports of the Deep Sea Drilling Project, Volume 60.

2 Donald M. Hussong (co-chief scientist), Hawaii Institute of Geophysics, Honolulu, Hawaii: Seiya Uyeda (co-chief scientist), Earthquake Research Institute, University of Tokyo, Tokyo, Japan; René Blanchet, Université de Bretagne Occidentale, Brest, France; Ulrich Bleil, Institut für Geophysik, Ruhr Universität, Bochum, Federal Republic of Germany; C. Howard Ellis, Marathon Oil Company, Denver Research Center, Littleton, Colorado; Timothy J. G. Francis, Institute of Oceanographic Sciences, Surrey, United Kingdom: Patricia Fryer, Hawaii Institute of Geophysics, Honolulu, Hawaii; Ki-Iti Horai, LamontDoherty Geological Observatory, Palisades, New York; Stanley Kling, Marine Life Research Group, Seripps Institution of Oceanography, La Jolla, California (present address: 416 Shore Arizona, Tucson, Arizona; Kazuaki Nakamura, Earthquake Research Institute, University of Tokyo, Tokyo, Japan; James H. Natland, Deep Sea Drilling Project, Scripps Institution of Oceanography, La Jolla, California; Gordon H. Packham, Department of Geology and Geophysics, University of Sydney, Sydney, N.S.W. Australia; and Anatoly Sharaskin, Vernadsky Institute of Geochemistry, U.S.S.R. Academy of Sciences, Moscow, U.S.S.R.

- Oldest sediments containing age-diagnostic fossils. Cores 13 through 15 cannot be assigned a paleontologic age.
}

Number of holes: 2 of 2

Number of cores: 15

Total length of cored section (m): 140

Total core recovered $(\mathrm{m}): 37.75$

Core recovery $(\%): 26.9$

Oldest sediment cored:**

Depth sub-bottom (m): 95

Nature: vitric mudstone

Age: early Pleistocene (1.6-1.8 m.y.)

Measured velocity $(\mathrm{km} / \mathrm{s}): 2.0$

Basement:

Depth sub-bottom (m): 118

Nature: aphyric pillow basalt

Velocity range $(\mathrm{km} / \mathrm{s}): 3.8-4.0$

Principal results: (Holes 456 and 456A)-Site 456, the second drilling target of the SP-4D objectives, is located in a small sediment pond on a local bathymetric high that was chosen because it is inaccessible to the bottom-transported volcanic sand which forced early abandonment of the first SP-4D site (Hole 455, located $17 \mathrm{~km}$ east of Site 456). At Hole 456, 169 meters was drilled with 19 percent recovery. The upper 56 meters is late Pleistocene (E. ovata) vitric mud and nannofossil ooze with ash layers (Unit I). In Hole 456, no nannofossils from the $G$. caribbeanica Subzone were recovered, but they are present in Hole 456A.

Unit II $(56-134 \mathrm{~m})$ is early Pleistocene (E. annula Zone) semilithified vitric mudstone and nannofossil chalk, showing cycles with bioturbated and non-bioturbated beds.

Unit III (134-169 m) is almost entirely aphyric pillow basalts with minor interbedded limestones and mudstones in the top few meters. These are recrystallized to a quartz-clay-wairakite assemblage near the contact with basalts, suggesting high $\left(200^{\circ} \mathrm{C}\right)$ alteration temperatures. The basalts are intensely altered-the upper part under non-oxidative and the lower part under oxidative conditions. The occurrence of pyrite, minor Fe-Mn hydrogenous sediments, and pore-water chemistry all imply that the alteration was hydrothermal. The altered basalts fractured easily, leading to drilling instability and early abandonment of the hole. To determine the lateral extent of alteration we offset 200 meters and drilled Hole $456 \mathrm{~A}$ which penetrated 159 meters.

The sediment of Hole 456A correlates closely with that of Hole 456, except that Unit II is thinner at Hole 456A, and igneous basement in the second hole was reached at 118 meters sub-bottom. Also, in spite of the proximity of the holes, the igneous lithologies differ (Hole 456A has a unit of plagioclase-phyric basalt, and alteration in Hole 456A is less pronounced). Greatly differing heat flow in the holes (ca. 2.7 HFU in Hole 456 and ca. 1.1 HFU in Hole $456 \mathrm{~A}$ ) may relate to the variability in extent of alteration. The basement is reversely magnetized, matching the negative anomaly of the site which was tentatively identified as between Anomaly 2 and $2 \mathrm{~A}$ ( $2.3 \mathrm{~m} . \mathrm{y}$. B.P.). Logging was not conducted at Hole 456 or Hole 456A because both holes caved in completely, to the extent that the bottom-hole assembly had to be blown off to retrieve the drill string at Hole 456A.

\section{BACKGROUND AND OBJECTIVES}

Site 456 (Figs. 1 and 2) was selected to fulfill the same objectives as SP-4D (Site 455), after drilling at Site 455

* Oldest sediment containing age-diagnostic fossils. 


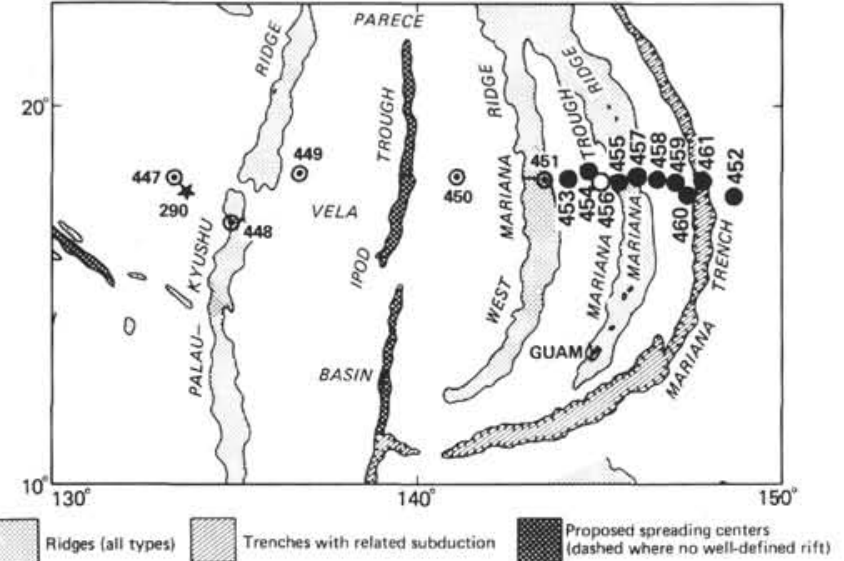

Figure 1. Location of Site 456 along the eastern portion of the South Philippine Sea drilled on Leg 60.

was thwarted by thick sequences of coarse sands. Investigation of these sands caused shipboard scientists to conclude that they were bottom-transported products of sub-aerial volcanism on the presently active Mariana Arc volcanoes (most likely Pagan and Alamagan, the closest islands). Thus, we considered the entire western apron of the active arc to be a poor candidate for further drilling, as the sand would be everywhere on it.

In order to make another attempt at the objectives of SP-4D (see Background and Objectives, site report on Site 455 ) we decided that the only reasonable chance for drilling would be if we could locate adequate sediment perched on a local bathymetric high which would be inaccessible to the bottom-transported sands. No such site had been observed during the site surveys or earlier Glomar Challenger profiling data. We therefore profiled with the Challenger over several bathymetric high areas near SP-4D until a suitable sediment pond was located (Fig. 3).

\section{OPERATIONS}

After departure from Site 455, approximately nine hours of surveying was required before a suitable sediment pond for Site 456 was located. The surveying was done with the $3.5-\mathrm{kHz}$ and $12-\mathrm{kHz}$ bathymetry system and the 120-cu. in. air-gun and single-channel hydrophone array. No magnetometer was towed, and the normal 1000 -foot tow cable on the hydrophone array was shortened to 500 feet. The towed gear was minimized so that the ship could make sharp turns during the relatively tight maneuvering that was anticipated during the surveying. A very small, but adequate, sediment pond was located and a $16.0-\mathrm{kHz}$ single-life beacon was deployed at 0433 local time on 12 April 1978.

The sediment pond was so small that sub-bottom reflectors were completely obscured by side echos from the surrounding ridges (Fig. 4). The $3.5-\mathrm{kHz}$ only showed about 20 meters of penetration (Fig. 5). The resultant uncertainty about sediment thickness prompted us to rig a short bottom-hole assembly (for explanation of this, see Operations section, Site 454). The same F93CK bit

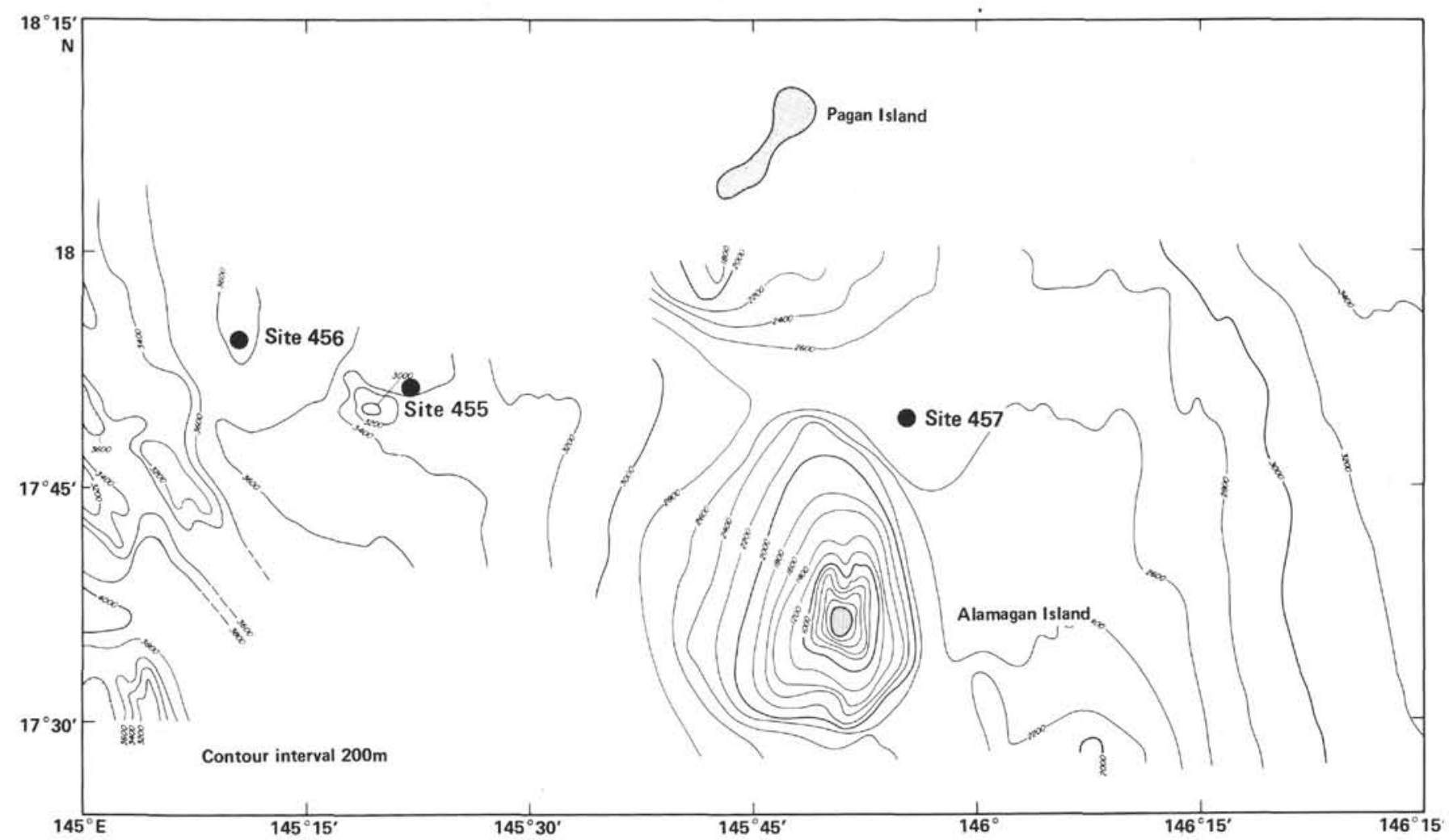

Figure 2. Bathymetry of a portion of the Mariana Trough near Site 456. 


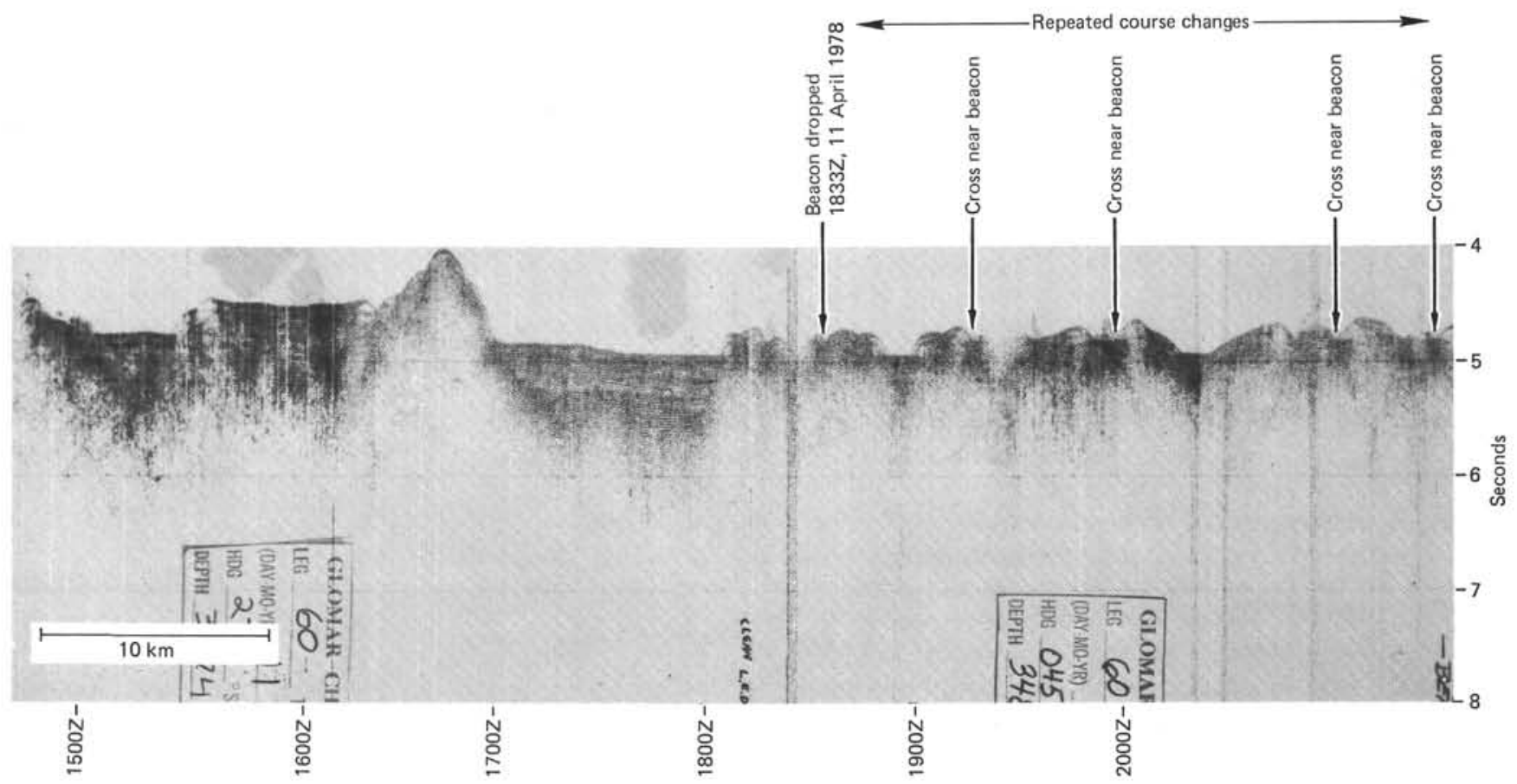

Figure 3. Portion of Glomar Challenger air-gun profile approaching Site 456 beacon drop, and positioning over beacon.

that was barely used at Site 455 was rigged for re-use at Site 456.

The corrected PDR depth was 3586 meters. We spudded-in at 3600.5 meters (3590.5 m below sea level) at 1355 on April 12, 1978. The coring summary is given in Table 1. Soft sediments were encountered and coring proceeded normally. The drilling rate for Hole 456 is shown in Figure 6A.

A Tokyo T-probe was run at 1825 on 12 April 1978 after Core 4 , at a depth of 29.0 meters sub-bottom.

Igneous rocks were encountered at a depth of 133.5 meters sub-bottom, and drilling slowed somewhat. These rocks were altered and highly fractured. The hole became unstable and started caving in as the highly fractured basalts were penetrated. During cutting of Core 19 we began experiencing excessive torquing and sticking at a depth of 168 meters sub-bottom (about $2 \mathrm{~m}$ from the base of that core interval). After Core 19 was raised, 30 barrels of mud was spotted in the hole in trying to clear it, but when the subsequent core was dropped the bit could only be lowered to 159 meters, indicating that 11 meters of hole had caved in. After drilling back down to only 166 meters, we decided to abandon the hole. The bit cleared the mudline at 2115 local time, 13 April 1978.

Although the depth of penetration at Site 456 had been limited, the recovered rocks were of great interest to the shipboard party. There were indications of localized hydrothermal alteration of the rocks, so it was felt that shifting location slightly to determine the lateral continuity of alteration of the recovered rocks would be valuable. We therefore decided to offset 200 meters to the east of Site 456 and drill another hole, designated Hole 456A, in the same sediment pond.
The drill string was raised only enough to clear bottom, so the same bottom-hole assembly and bit were used for Hole 456A as had been used at Hole 456.

The spud-in time at Hole 456 was 0005 on 14 April, at a drill string depth of 3591 meters below sea level. The coring summary is shown in Table 1, and the drill rate is shown in Figure 6B. After a mudline core was brought up, we washed down from 9.5 to 28.5 meters sub-bottom, since this interval of soupy sediments had been cored at the adjacent Site 456.

The Tokyo T-probe was run after Core 3 at a depth of 47.5 meters, and again after Core 5 at a depth of 66.5 meters below bottom.

The basement rocks were encountered in Core 11 at a depth of approximately 114 meters below the sea floor. As in the case of Hole 456, however, these rocks were highly fractured and again problems with hole stability developed. When the bit was raised after cutting Core 12 , some caving-in of the hole was noted, so 30 barrels of mud was flushed through the hole. Problems with torquing and sticking persisted, however, and by Core 14 the drill string became stuck several times. After Core 16, over 6 meters of the hole caved in. After freeing the bit from that cave-in, we decided that the hole was deep enough to make downhole logging practical, so the drill string was brought up only far enough to prepare for the logging. The bit was released at 0345,15 April 1978.

After the bit was dropped, the hole apparently completely caved in around the pipe at depths above that of the bumper sub. At this time plans to log the hole were dropped. After pulling as much as 580,000 pounds for over 8 hours, an explosive charge was lowered into the 


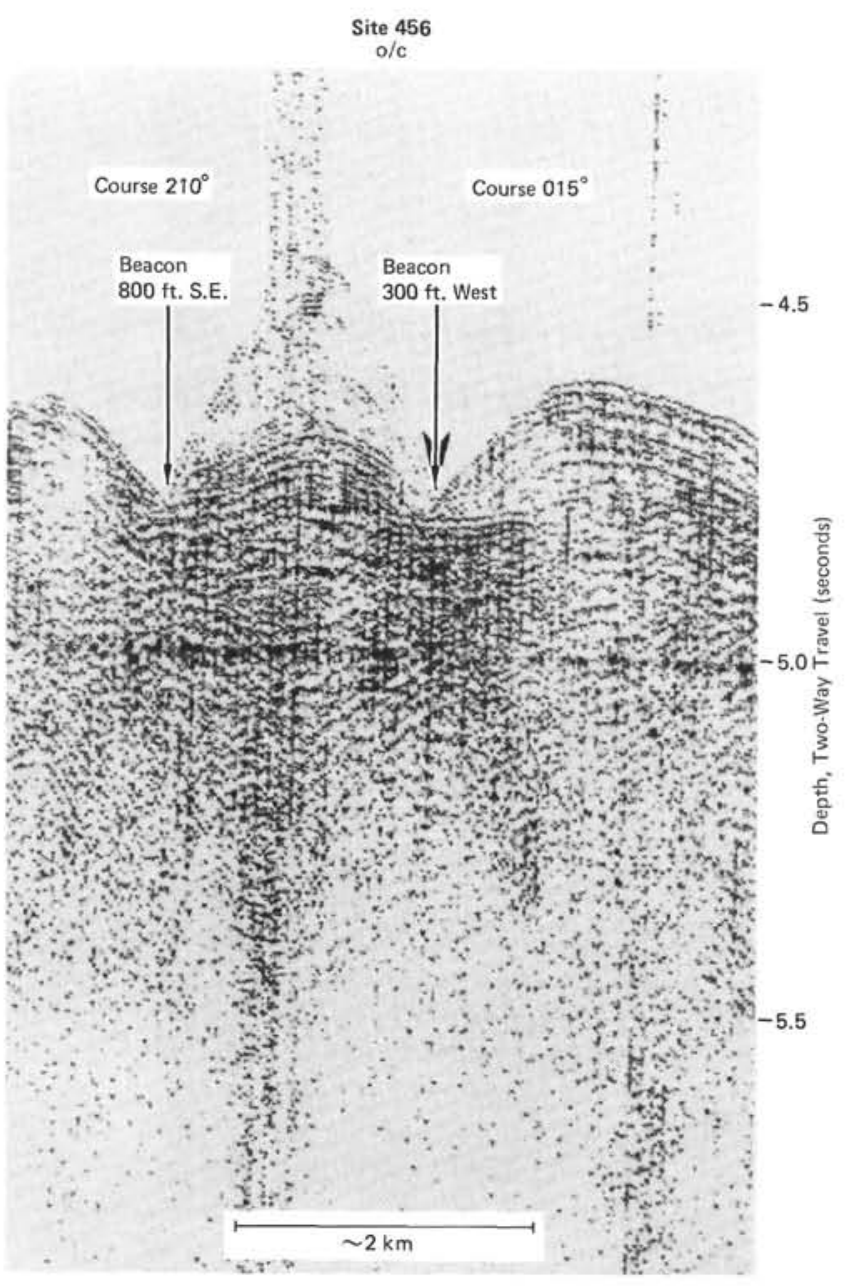

Figure 4. Blow-up of a portion of Figure 3 showing location of Site 456. pipe to blow off the bottom of the hopelessly stuck drill string. On the third attempt the pipe was severed at 1900, 15 April.

The pipe string was severed two joints above the bottom-hole assembly, so that all of that mechanism, including the only bit released sub-assembly on the ship, was lost. This meant that no more logging could be done on the leg until a bit-release sub was supplied.

The drill string was aboard, secured, and we departed for Site 457 on 0051, 16 April 1978.

\section{LITHOLOGY}

At Site 456 two holes were drilled reaching a subbottom depth of 169 meters in Hole 456 and 159 meters in Hole 456A. Three units can be distinguished, with hiatus between Unit I and II in Hole 456 (Fig. 7).

Unit I: $0-56$ meters; Cores 1 through 7 at Hole 456. Cores 1 through 4 at Hole 456A; late Pleistocene (E. ovata Subzone), 0-0.9 m.y.

Dominant lithologies are unlithified vitric mud and marly nannofossil ooze with silty and sandy vitric ash layers. In the upper 10 meters, marly siliceous oozes with diatoms and radiolarians are present.

Ash layers form darker olive-black bands or patches; oozes and mud are lighter (mainly light olive-gray).

Volcanic glass is the main component of the ash layers; it is either fresh and colorless or pale brown with pipe vesicles.

Unit II: $56-118$ meters, Cores 4 through 11 at Hole 456A. 56-134 meters, Cores 8 through 15 at Hole 456; early Pleistocene.

The following changes in lithology occur at the top of Unit II: the degree of lithification changes from stiff mud to semi-lithified mudstone; colors become darker (dark greenish gray, dark grayish green, greenish black);

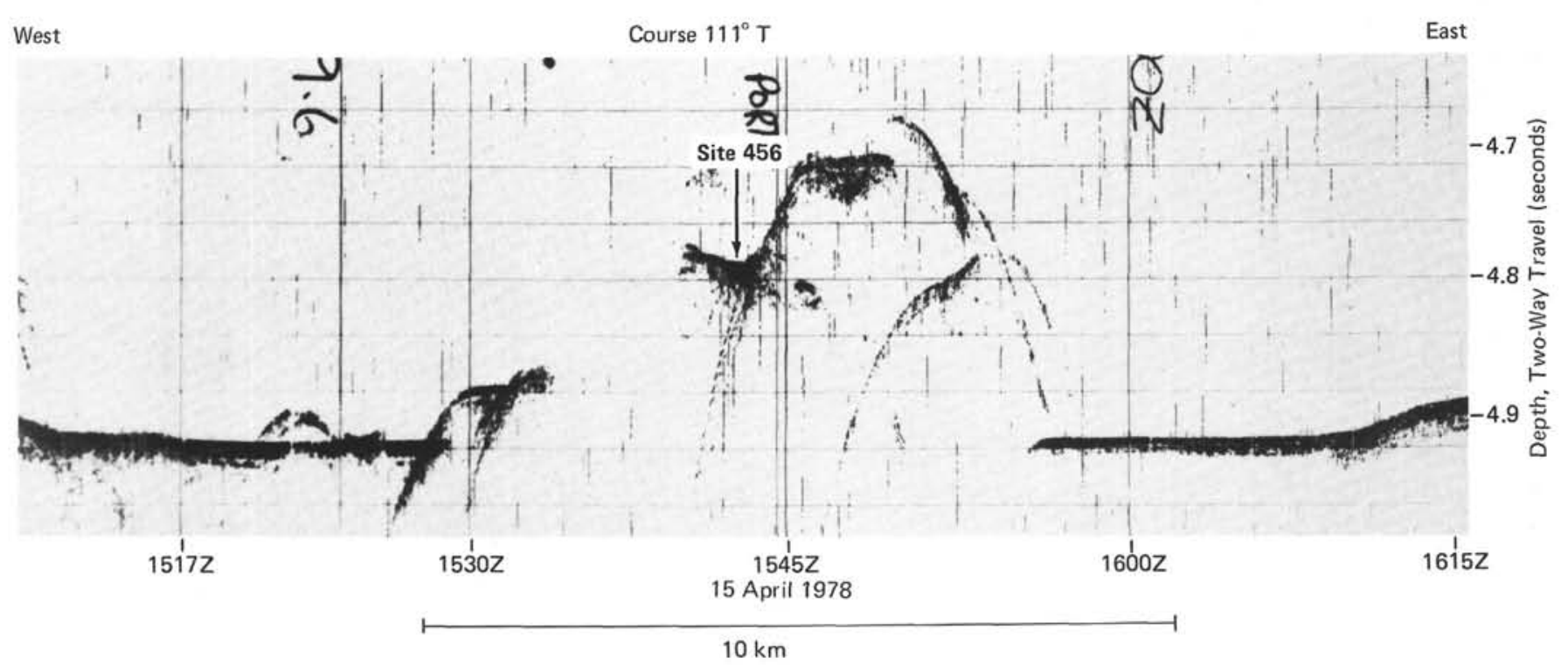

Figure 5. Portion of Glomar Challenger 3.5-kHz record over Site 456 showing small dimensions of sediment pond and the elevation of the pond about 100 meters above the arc volcaniclastic sediment apron. 
Table 1. Coring summary, Holes 456 and 456A.

\begin{tabular}{|c|c|c|c|c|c|c|c|}
\hline Core & $\begin{array}{c}\text { Date } \\
\text { (April } \\
1978 \text { ) }\end{array}$ & Time & $\begin{array}{l}\text { Depth from } \\
\text { Drill Floor } \\
\text { (m) }\end{array}$ & $\begin{array}{l}\text { Depth below } \\
\text { Sea Floor } \\
\text { (m) }\end{array}$ & $\begin{array}{l}\text { Length } \\
\text { Cored } \\
(\mathrm{m})\end{array}$ & $\begin{array}{l}\text { Length } \\
\text { Recovered } \\
\text { (m) }\end{array}$ & $\begin{array}{c}\text { Recovery } \\
(\%)\end{array}$ \\
\hline \multicolumn{8}{|c|}{ Hole 456} \\
\hline 1 & 12 & 1437 & $3600.5-3601.0$ & $0.0-0.5$ & 0.5 & 0.50 & 100 \\
\hline 2 & 12 & 1550 & $3601.0-3610.5$ & $0.5-10.0$ & 9.5 & 7.04 & 74.1 \\
\hline 3 & 12 & 1656 & $3610.5-3620.0$ & $10.0-19.5$ & 9.5 & 2.15 & 22.6 \\
\hline 4 & 12 & 1821 & $3620.0-3629.5$ & $19.5-29.0$ & 9.5 & 2.87 & 30.2 \\
\hline 5 & 12 & 2123 & $3629.5-3639.0$ & $29.0-38.5$ & 9.5 & 0 & 0 \\
\hline 6 & 12 & 2238 & $3639.0-3648.5$ & $38.5-48.0$ & 9.5 & 3.93 & 41.3 \\
\hline 7 & 12 & 2355 & $3648.5-3658.0$ & $48.0-57.5$ & 9.5 & 2.61 & 27.4 \\
\hline 8 & 13 & 0129 & $3658.0-3667.5$ & $57.5-67.0$ & 9.5 & 0.06 & 0.6 \\
\hline 9 & 13 & 0317 & $3667.5-3677.0$ & $67.0-76.5$ & 9.5 & 1.35 & 14.2 \\
\hline 10 & 13 & 0447 & $3677.0-3686.5$ & $76.5-86.0$ & 9.5 & 3.94 & 41.5 \\
\hline 11 & 13 & 0554 & $3686.5-3696.0$ & $86.0-95.5$ & 9.5 & 0.97 & 10.2 \\
\hline 12 & 13 & 0705 & $3696.0-3705.5$ & $95.5-105.0$ & 9.5 & 1.39 & 14.6 \\
\hline 13 & 13 & 0814 & $3705.5-3715.0$ & $105.0-114.5$ & 9.5 & 0.36 & 3.8 \\
\hline 14 & 13 & 0920 & $3715.0-3724.5$ & $114.5-124.0$ & 9.5 & 1.24 & 12.6 \\
\hline 15 & 13 & 1026 & $3724.5-3734.0$ & $124.0-133.5$ & 9.5 & 0.16 & 1.8 \\
\hline 16 & 13 & 1227 & $3734.0-3743.5$ & $133.5-143.0$ & 9.5 & 2.18 & 22.9 \\
\hline 17 & 13 & 1537 & $3743.5-3753.0$ & $143.0-152.5$ & 9.5 & 0.50 & 5.3 \\
\hline 18 & 13 & 1747 & $3753.0-3762.0$ & $152.5-161.5$ & 9.0 & 0.57 & 6.3 \\
\hline 19 & 13 & 2212 & $3762.0-3769.5$ & $161.5-169.0$ & 7.5 & 0.41 & 5.5 \\
\hline Total & & & & & 169.0 & 32.23 & 19.0 \\
\hline \multicolumn{8}{|c|}{ Hole 456A } \\
\hline 1 & 14 & 0102 & $3601.0-3610.5$ & $0.0-9.5$ & 9.5 & 9.61 & 100 \\
\hline 2 & 14 & 0236 & $3629.5-3639.0$ & $28.5-38.0$ & 9.5 & 0.05 & 0.5 \\
\hline 3 & 14 & 0345 & $3639.0-3648.5$ & $38.0-47.5$ & 9.5 & 3.63 & 38.2 \\
\hline 4 & 14 & 0648 & $3648.5-3658.0$ & $47.5-57.0$ & 9.5 & 0.75 & 7.9 \\
\hline 5 & 14 & 0804 & $3658.0-3667.5$ & $57.0-66.5$ & 9.5 & 3.78 & 39.8 \\
\hline 6 & 14 & 1057 & $3667.5-3677.0$ & $66.5-76.0$ & 9.5 & 3.37 & 35.4 \\
\hline 7 & 14 & 1206 & $3677.0-3686.5$ & $76.0-85.5$ & 9.5 & 3.25 & 34.2 \\
\hline 8 & 14 & 1320 & $3686.5-3696.0$ & $85.5-95.0$ & 9.5 & 2.20 & 23.1 \\
\hline 9 & 14 & 1436 & $3696.0-3705.5$ & $95.0-104.5$ & 9.5 & 3.23 & 34.0 \\
\hline 10 & 14 & 1545 & $3705.5-3715.0$ & $104.5-114.0$ & 9.5 & 5.54 & 58.3 \\
\hline 11 & 14 & 1812 & $3715.0-3724.5$ & $114.0-123.5$ & 9.5 & 0.82 & 8.6 \\
\hline 12 & 14 & 1957 & $3724.5-3734.0$ & $123.5-133.0$ & 9.5 & 0.71 & 7.0 \\
\hline 13 & 14 & 2241 & $3734.0-3743.5$ & $133.0-142.5$ & 9.5 & 0.28 & 2.9 \\
\hline 14 & 15 & 0100 & $3743.5-3753.0$ & $142.5-152.0$ & 9.5 & 0.28 & 2.9 \\
\hline 15 & 15 & 0347 & $3753.0-2760.0$ & $152.0-159.0$ & 7.0 & 0.25 & 3.5 \\
\hline Total & & & & & 140.0 & 37.75 & 27.0 \\
\hline
\end{tabular}
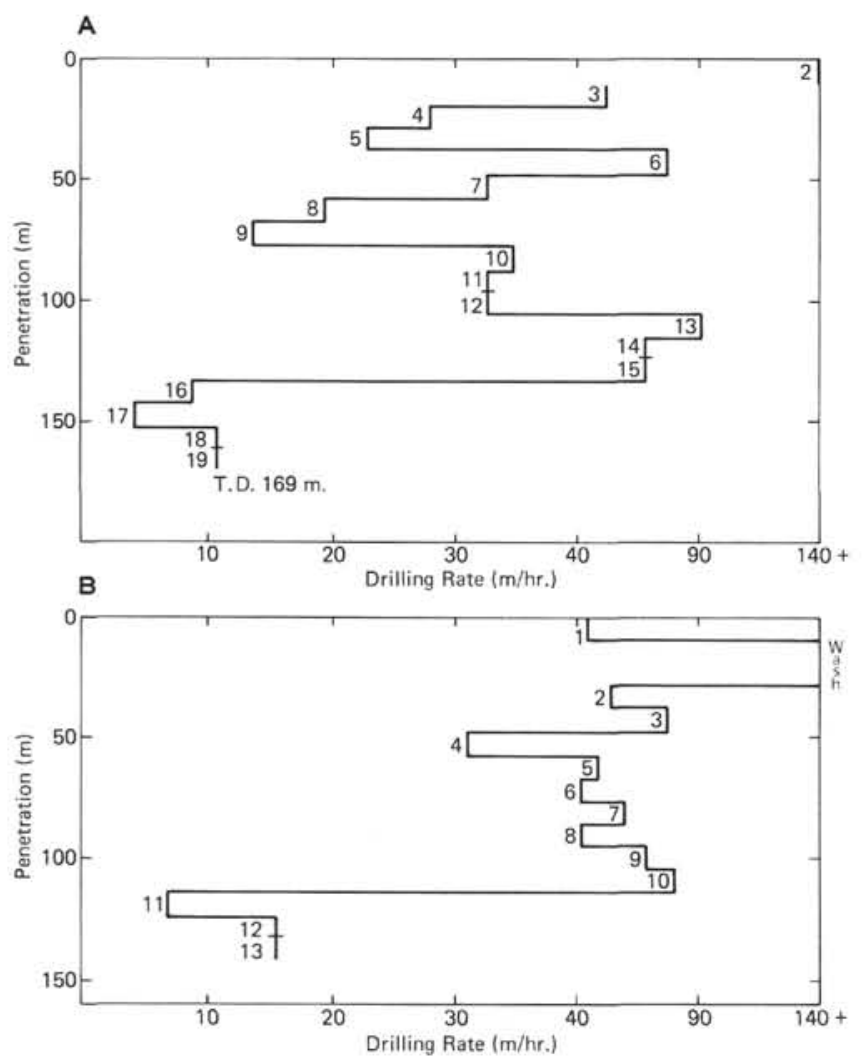

Figure 6. Drilling rate for (A) Hole 456 and (B) Hole 456A, in meters per hour for each core. T.D. is total depth sub-bottom. Core numbers are shown on the figure. cycles with bioturbated and non-bioturbated lithified turbidite are present. Volcanic glass is highly altered to clays.

The dominant lithologies of Unit II are bioturbated vitric mudstone and vitric nannofossil chalk, and laminated, graded silty to sandy vitric tuff (turbidite). Burrows are frequently filled with vitric nannofossil ooze.

Downward in Unit II, beginning in Core 14 at Hole 456 and in Core 8 at Hole 456A, the colors become progressively pale green and grayish red-purple. At the same time the percentage of strongly altered volcanic glass increases; green clays (mainly chlorite) are developed. In Cores 10 (Hole 456A) and 14 (Hole 456), which in each case is one core above the basalts, numerous globular crystals of calcite of silt and clay size appear.

Unit III: At Hole 456A this unit begins at 118 meters (this depth is estimated based on the proportion of sediment pebbles and fragments above igneous fragments in the 82 centimeters recovered in Core 11) and was cored to 159 meters (Core 15). It is almost entirely basalt (see Igneous and Metamorphic Rocks section). At Hole 456 this unit begins at 134 meters and was cored to 169 meters (Cores 16 through 19). In Cores 16 and 17 some sedimentary rocks are interbedded with basalt samples.

In Core $16,10-12 \mathrm{~cm}$, a recrystallized calcareous vitric tuff with abundant euhedral pyrite and iron hydroxide patches occurs. At $15-17 \mathrm{~cm}$, a highly vesicular piece of vitric mudstone is recrystallized with calcite crystals, wairakite (Natland and Hekinian, this volume), iron hydroxides, and remnants of volcanic glass 


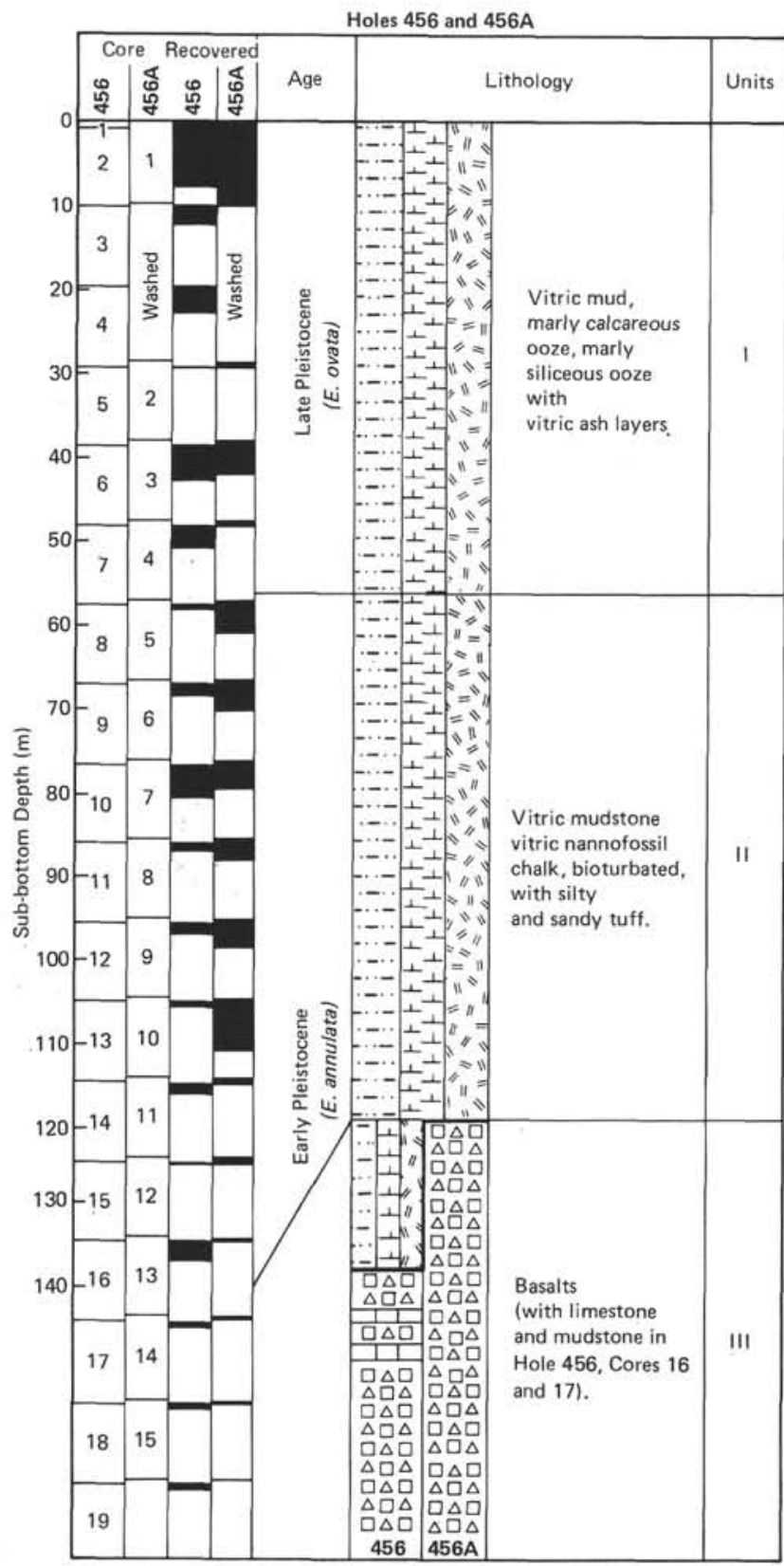

Figure 7. Combined lithologic summary for Holes 456 and 456A.

and feldspar. At $44-47 \mathrm{~cm}$ a piece recrystallized tuff with abundant sulfides is included in the basalt. The contact with this piece shows a darker continuous margin in the limestone. The adjacent basalt groundmass is largely replaced by carbonate with associated sulfides. These gradations are probably the result of hydrothermal processes superimposed on an original baked contact.

It is evident, then, that some sediments predate the basaltic extrusions and were baked upon contact with the lavas. The growth of calcite crystals and perhaps the red coloration in the lower part of Unit II could also have resulted from the same thermal process or be related to the hydrothermal alteration of the basalt.
The top of the basalts is about 16 meters deeper at Hole 456 than at Hole 456A (only about $200 \mathrm{~m}$ apart). This may indicate either a fault, or that different flows interbedded at different levels of the stratigraphic column (see Site 454), or merely that there is an inclined surface to basement.

\section{BIOSTRATIGRAPHY}

\section{Summary}

Sediments that overlie the basalts at Site 456 can be dated throughout most of the sequence with the use of calcareous nannofossils and with radiolarians in the upper part. All of the early and late Pleistocene nannofossil biostratigraphic zones can be recognized. The oldest nannofossil zone recognized in samples from this site, the Emiliania annula Subzone, ranges from 1.6 to 1.8 m.y. (Bukry, 1975).

\section{Nannofossils}

The same sequence of Pleistocene zones and subzones can be recognized in samples from both holes except for the Gephyrocapsa caribbeanica Subzone which was not recognized in Hole 456, probably because of inadequate sample recovery.

The following nannofossil zones can be recognized. The Holocene-late Pleistocene Emiliania huxleyi Zone is seen in Samples 456-1,CC through 2-3, 65-66 cm and 456A-1-1, 90-91 cm. The late Pleistocene Emiliania ovata Subzone of the Gephyrocapsa oceanica Zone is recognized in Samples 2-4, 65-66 cm through 7,CC in Hole 456 and in Samples 1-3, 90-91 cm through 4,CC in Hole 456A. The early Pleistocene Gephyrocapsa caribbeanica Subzone is not recognized in Hole 456, but it is seen in Samples 5-1, 86-87 cm through 5-3, 34-35 cm in Hole 456A. The early Pleistocene Emiliania annula Subzone of the Crenalithus doronicoides Zone is determined in Samples 8,CC through 13,CC in Hole 456 and Samples 5,CC through 10-2, 60-61 cm in Hole 456A.

Samples 456-14-1, 80-81 cm through $16-1,0.1 \mathrm{~cm}$ and $456 \mathrm{~A}-10-3,44-45 \mathrm{~cm}$ through $10, \mathrm{CC}$ contain nannofossils, but they cannot be assigned to a biostratigraphic zone with any confidence because no agediagnostic species are present.

No evidence was found for the early Pleistocene Gephyrocapsa caribbeanica Subzone of the Crenalithus doronicoides Zone in Hole 456. However, this subzone is present in samples from Sections 1 through 3 of Core 5. These sections are depth-equivalent to Core 8 of Hole 456 , an interval that did not have sample recovery. Consequently, the $G$. caribbeanica Subzone is probably present in the interval represented by Core 8 in Hole 456.

\section{Radiolarians}

Well-preserved to moderately well-preserved radiolarians occur in the late Quaternary part of the sequence at Site 456. Species required to recognize the Quaternary zones of Nigrini (1971) are very rare even in the richest assemblages. 
The Buccinosphaera invaginata Zone can be identified in Hole 456, Core 1, 2, 3; and in Hole 456A, Core 1. The Collosphaera tuberosa Zone is represented in Hole 456, Core 4; and in Hole 456A, Core 1.

\section{Foraminifers (V. A. Krasheninnikov)}

Impoverished Quaternary foraminiferal assemblages occur in samples from Holes 456 and 456A. Species diversity is sufficient for zonal assignment of some of the sampled intervals. Samples 456-1-1, 50-52 cm through 456-2-5, 62-64 $\mathrm{cm}$ can be placed in the late Quaternary Globigerina calida calida Subzone. While Samples 456-2-4, 62-64 cm through 456-6-2, 50-52 cm can only be assigned an undifferentiated Quaternary age, it is noted that Globorotalia truncatulinoides and $G$. tosaensis occur together in the early Quaternary Samples 456-6-3, 50-52 cm through 456-10-3, 63-65 cm.

In Hole 456A, Samples 1-1, 50-52 cm through 9-2, $25-27 \mathrm{~cm}$ can only be assigned an undifferentiated Quaternary age, but Samples 10-1, 66-68 cm through $10-4,32-34 \mathrm{~cm}$ can be placed in the early Quaternary.

\section{ACCUMULATION RATES}

Sediment accumulation has been calculated in kilograms of water-free sediment on each square centimeter. The calculation has been done in the same way as for Site 453, but without averaging. The results (Fig. 8) are very similar for Holes 456 and $456 \mathrm{~A}$. In both, the depositional history can be divided into four segments.

\begin{tabular}{|c|c|c|c|}
\hline \multirow{2}{*}{\multicolumn{2}{|c|}{ Interval }} & \multicolumn{2}{|c|}{ Hole 456} \\
\hline & & $\begin{array}{c}\text { Depth } \\
\text { below } \\
\text { Sea Floor } \\
(\mathrm{m})\end{array}$ & $\begin{array}{l}\text { Accumulation } \\
\text { Rate } \\
\text { (kg/cm²/m.y.) }\end{array}$ \\
\hline 1) & $\begin{array}{l}\text { Holocene-latest Pleistocene } \\
(0-0.3 \text { m.y.) }\end{array}$ & $0-<4.7$ & 1.9 \\
\hline 2) & $\begin{array}{l}\text { Early late Pleistocene } \\
(0.3-0.9 \text { m.y. })\end{array}$ & $<4.7->50.6$ & 7 \\
\hline 3) & $\begin{array}{l}\text { Later early Pleistocene } \\
(0.9-1.6 \text { m.y. })\end{array}$ & $>50.6-<57.6$ & $<0.8$ \\
\hline 4) & $\begin{array}{l}\text { Earliest Pleistocene and ?older } \\
(1.6->\text { ? } 1.8 \text { m.y.) }\end{array}$ & $<57.6-134.0$ & 47 \\
\hline
\end{tabular}

Hole 456A

\begin{tabular}{|c|c|c|c|}
\hline & Interval & $\begin{array}{l}\text { Depth } \\
\text { below } \\
\text { Sea Floor } \\
\text { (m) }\end{array}$ & $\begin{array}{l}\text { Accumulation } \\
\text { Rate } \\
\text { (kg/cm } 2 / \mathrm{m} . \mathrm{y} .)\end{array}$ \\
\hline & $\begin{array}{l}\text { Holocene-latest Pleistocene } \\
(0-0.3 \text { m.y.) }\end{array}$ & $0->3.9$ & 1.3 \\
\hline 2) & $\begin{array}{l}\text { Early late Pleistocene } \\
(0.3-0.9 \text { m.y. })\end{array}$ & $>3.9-53.1$ & 8 \\
\hline 3) & $\begin{array}{l}\text { Later early Pleistocene } \\
(0.9-1.6 \text { m.y. })\end{array}$ & $53.1-60.6$ & 1.1 \\
\hline 4) & $\begin{array}{l}\text { Earliest Pleistocene and ?older } \\
(1.6->? 1.8 \text { m.y.) }\end{array}$ & $60.6-118$ & 36 \\
\hline
\end{tabular}

The site is located in a small pond on the crest of a ridge on the same side of the Mariana Trough spreading axis as the active arc, and hence the changing rate of sedimentation would be caused by variations in the volcanic activity on the arc. The abnormally high initial rate of deposition in the early Pleistocene may contain a component of locally derived sediment as well as that derived from the arc. Sediments of comparable age were unfortunately not penetrated at Site 455 . Sedimentation rates in the three upper segments at Site 456 correlate with the three recognized at Site 455 and indicate a much higher level of volcanic activity between 0.3 and 0.9 m.y.

\section{STRATIGRAPHIC SYNTHESIS}

Site 456 is located in a pond on a ridge some $17 \mathrm{~km}$ west of Site 455 . Three rock units were drilled at Site 456. From bottom to top, these are (Hole 456 given first): Unit III: 35 meters ( $41 \mathrm{~m}$ in Hole $456 \mathrm{~A}$ ) of basalt at the base with a little mudstone and limestone interbedded at the top; Unit II: 78 meters $(62 \mathrm{~m}$ at Hole 456A) of a strongly burrowed sedimentary sequence which is brown and green at the base, comprising green sandy and silty sediments and brown nannofossil chalks passing up into green to gray vitric mudstone and minor silty and sandy tuff. These are all deposited in the early Pleistocene subzone of Emiliania annula (1.6 to 1.8 m.y.) except for 2.5 meters at the top of the unit in Hole $456 \mathrm{~A}$ only that is from the early Pleistocene subzone Gephyrocapsa caribbeanica, and Unit I: a sequence of 56 meters of soft vitric muds, marly ooze, and ash layers deposited in the late Pleistocene to Holocene, subzone of Emiliania ovata and above (less than 0.9 m.y.).

The uppermost unit in Site 456 is similar to the first 10 cores at Site 455 . The cores through this unit from Hole 456 located near the center of the pond contain more sand than Hole 456A located near the edge of the pond. A layer of slumped sediment over 2 meters thick occurs in Hole 456A. The evidence could imply a local submarine channel near Hole 456, whereas Hole 456A is dominated by over-bank deposits.

The basaltic rocks of the third unit are within (or younger than) the subzone of $E$. annula (1.6 to 1.8 m.y.).

The occurrence of recrystallized calcareous tuff incorporated into some of the upper basalts shows that some sediments predate the latest phase of basaltic extrusions. The growth of calcite crystals and pyrite, and perhaps the red coloration in the lower part of Unit II, could also have resulted from the same thermal process associated with the emplacement of basalt or be related to a later hydrothermal alteration of the underlying basalt.

\section{INTERSTITIAL WATER GEOCHEMISTRY}

Seven samples were taken for pore water analysis at Site 456-three from Hole 456 and four from Hole 456A. The data are listed and discussed in Gieskes and Johnson (this volume). There are small variations in $\mathrm{Mg}^{2+}$ and $\mathrm{Ca}^{2+}$ near basement in both holes that suggest (1) that some exchange of seawater $\mathrm{Mg}$ for $\mathrm{Ca}$ in tuffs and/or basement has occurred, and (2) the sea water may now be circulating in basement. The latter trend is indistinct, however, and may simply reflect contamination with sea water during transport of cores from the seabed to the ship. 


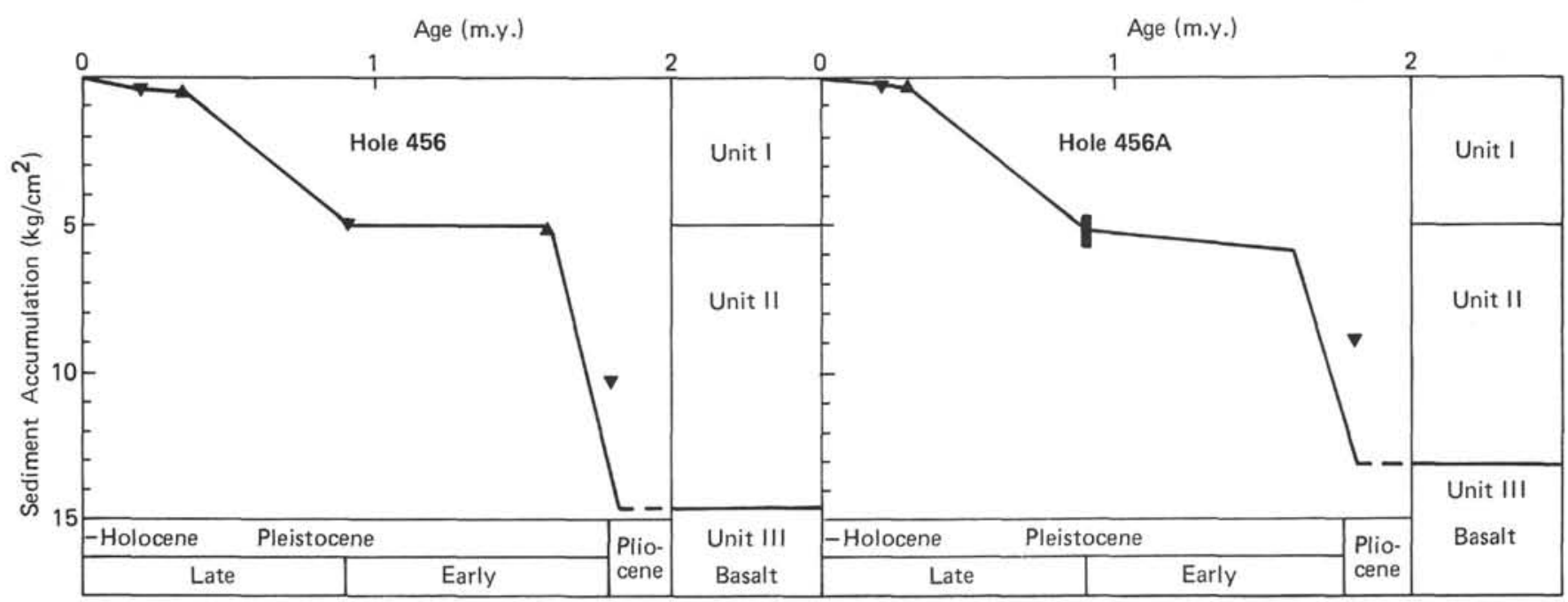

Figure 8. Sediment accumulation $\left(\mathrm{kg} / \mathrm{cm}^{2}\right)$ versus age for Holes 456 and $456 \mathrm{~A}$.

\section{IGNEOUS AND METAMORPHIC ROCKS}

\section{Summary}

The basalts recovered in the two holes at Site 456 are fragments of pillows, most of them aphyric, some quite vesicular. They have a complex chemical stratigraphy, and have undergone extensive alteration. The alteration is most intense at the top of basement in both holes, where high-temperature (evidently) hydrothermal fluids transformed the basalts to pyrite- and chlorite-rich greenschist facies metabasites. The alteration grades downward through a zone rich in reddish potash-rich smectite and palagonite, thence to fresh basalts. In each hole, recovery and ease of drilling diminished downward as fresher basalts were encountered. The pattern of alteration in the two holes suggests that the hydrothermal fluids migrated horizontally at the top of basement beneath considerably less permeable sedimentary rocks.

Based on whole-rock chemical analyses (Wood et al., this volume), four distinct chemical types of basalt occur in the two holes, as shown on Figure 9. The geochemistry will be discussed more fully in a subsequent section. The lithology and petrography will be described below, grouped under the basic chemical types shown on Figure 9. The chemical types are designated by B, for basalt, and subscripts 1 and 2, for basalt types recovered in both holes, and subscripts $\mathrm{A}$ and $\mathrm{B}$, for basalts recovered only in Hole 456A.

\section{Unit $B_{1}$ (Cores 16 and 17, Hole 456, and Core 11, Hole 456 A)}

\section{Lithology}

The basalts of this chemical type represent the glassy margins and more crystalline interiors of pillow basalt fragments. The fragments are highly altered, most showing highly altered darker glassy rinds (Fig. 10). These are dark greenish gray to pale grayish green and show an intricate pattern of textural and color variations through an interval of about $1.5 \mathrm{~cm}$ at the periphery of the fragments. The glass is fractured and generally contains fine white or gray veins of clays and carbonate (Fig. 11). It appears that a single large pillow, in the upper portion of Core $16(19-74 \mathrm{~cm})$, was recovered in fragments (Fig. 12). The uppermost and lowest pieces of the pillow both show formerly glassy rinds. The rinds of this large pillow basalt are smoothly curving. The rinds of other pillow fragments, notably Piece 1 of Section 16-2, are irregular in shape. Welldeveloped pillow rinds are present in a number of small altered samples in the bottom of Section 16-1 (121, 140, $147 \mathrm{~cm}$ ). These are similar to rinds present on the larger pillow fragments higher in the cores; that is, they are gently curving or approximately straight across the periphery and possibly represent pieces broken from the surface of larger pillows. The first piece of basalt in the top of Section 16-2 has an altered glass rind that is irregular in shape (Fig. 11). Pieces of pillow basalt in Section 17-1 also have altered rinds that are irregular in shape.

Most of the basalts in Hole 456 are aphyric to very sparsely phyric and for the greater part lack vesicles. Some vesicular basalt is present in the lowest portion of Section 16-2. The basalt appears to have intruded or to be interbedded with recrystallized calcareous tuffs in Section 16-1 (Fig. 13). One piece of such rock has been incorporated into the basalts (Section 456-16-1, Pieces $7 \mathrm{a}$ and $7 \mathrm{~b}$; Fig. 14).

The basalts recovered in Hole 456A are overlain by carbonate-cemented vitric tuff and silicified mudstone in the first core (Core 11). The basalt from Core 11 is highly altered and has the same characteristics as the basalts of the green zone in Hole 456 (see below for details of the character of the alteration). The samples show formerly glassy rinds, now highly altered, and have relics of spherulitic textures just beneath the rinds. These fragments are probably pillow basalt. 

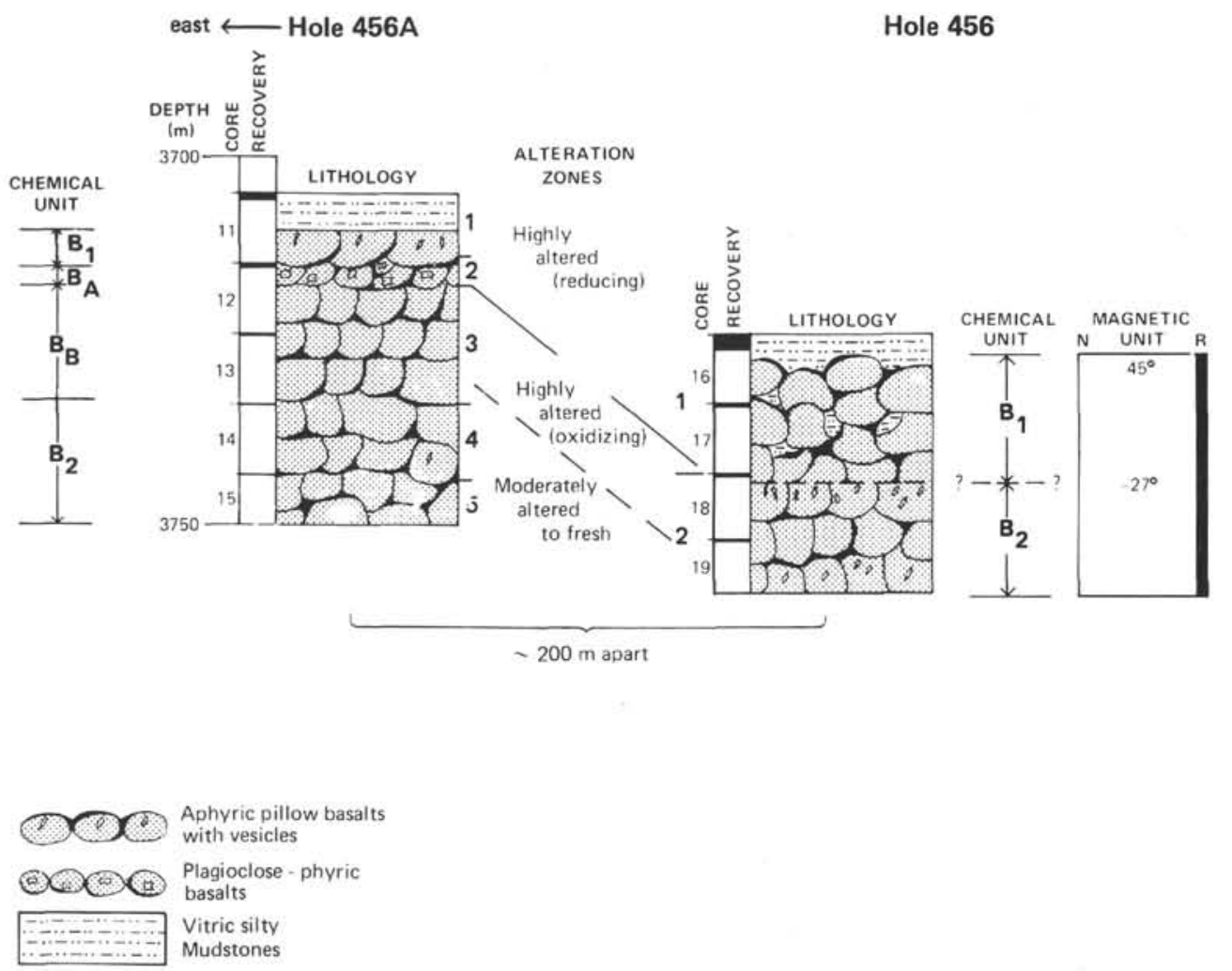

Figure 9. Basement lithologic, chemical, and magnetic stratigraphy, Site 456.
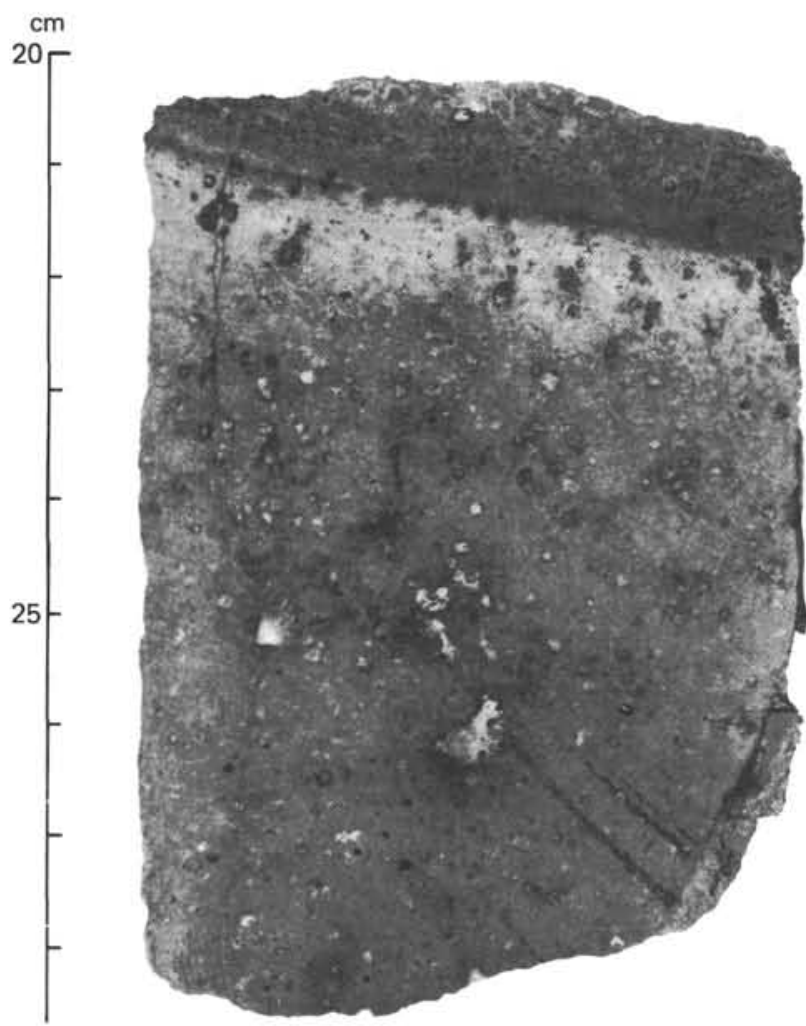

Figure 10. Bottom segment of pillow fragment, Hole 456, Section 16-1, Piece 7B. An altered glassy rind is at bottom. Vugs and vesicles are filled with secondary minerals.

\section{Petrography}

The basalts of chemical type $\mathrm{B}_{1}$ are aphyric to sparsely phyric, containing somewhat less than 1 percent of rounded (resorbed) microphenocrysts of labradorite (up to $1-1.5 \mathrm{~mm}$ in size). The texture of the groundmass is typical of pillow basalt. It changes from spherulitic just beneath the outer glassy rinds to intersertal or subophitic in the most crystalline interiors. The spherulites in the outermost portions of the pillows consist of brown radial fibers centered on plagioclase crystallites. About $1-5 \mathrm{~cm}$ farther into pillow interiors, plagioclase spherulites become more fan-like in appearance, and eventually become intergrown with clinopyroxene in sworls and spoke-like arrays. A range of plagioclase crystal sizes and morphologies is present from skeletal microlites to spherulitic crystallites. Although the sworllike aggregates of plagioclase are still intact, the general high degree of alteration makes it difficult to estimate the primary composition of the groundmass.

The secondary mineral assemblage consists of clay minerals (smectite and others), carbonate, quartz, opaline silica, pyrite, and in some samples chlorite, albite, and epidote. Carbonates, siliceous material, and pyrite also fill many vesicles (3-5\% of the rock volume; $0.1-$ $5.0 \mathrm{~mm}$ in size). Others are lined with clays. Quartz and opaline silica are especially abundant in vesicles and the groundmass of the basalts, which have a bleached appearance. Pyrite usually has partially decomposed (or imperfectly crystallized) margin around more massive 


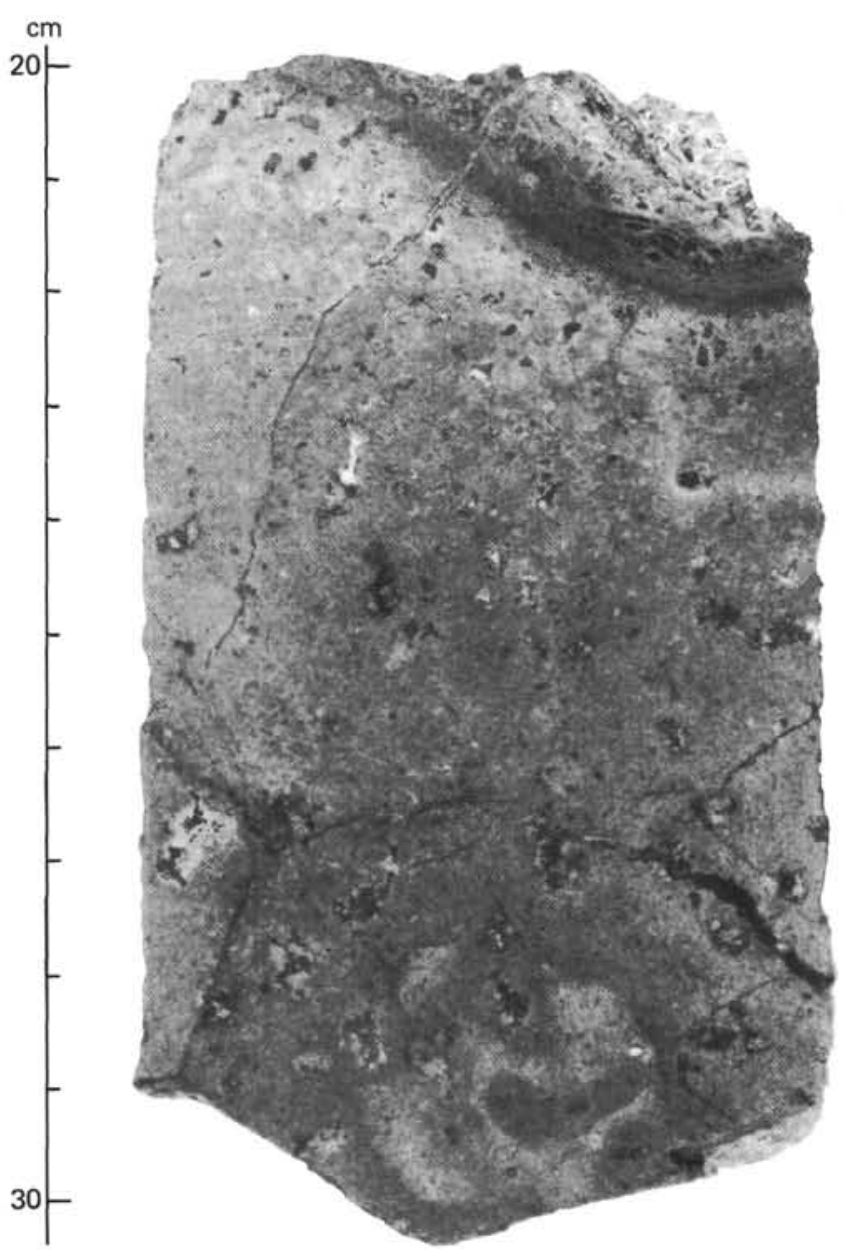

Figure 11. Bottom of pillow with curved glassy, now altered, rim, Hole 456, Section 16-2, Piece 1A.

interiors. Where it has had the freedom to do so, it has grown in its typical cubic crystal morphology. It is particularly abundant around the clumps of larger skeletal or tabular plagioclase crystals. One sample (Hole 456, Core 16, Pieces 7A and 7B) has an incorporated calcareous sedimentary rock fragment and very abundant secondary carbonate. Adjacent to the inclusion is a thin transition zone where carbonate has replaced nearly all but skeletal plagioclase crystals in the basalt. Pyrite also is concentrated in a few places along this transition zone.

\section{Unit $B_{2}$ (Cores 18 and 19, Hole 456, Cores 14 and 15, Hole 456A)}

\section{Lithology}

Recovery of this unit in both holes is very low. In Hole 456, a sequence of apparently one single aphyric basalt pillow was recovered in Core 18 . The pieces are intensely altered to grayish brown and light olive brown hues, and are coarser grained toward the middle of the core. Orange Fe hydroxides, Mn oxides, and calcite coat fracture surfaces in the basalts. The material in Core 19 is similar, but fresher. At least two cooling units are represented. The lowest piece in the core has fresh glass.

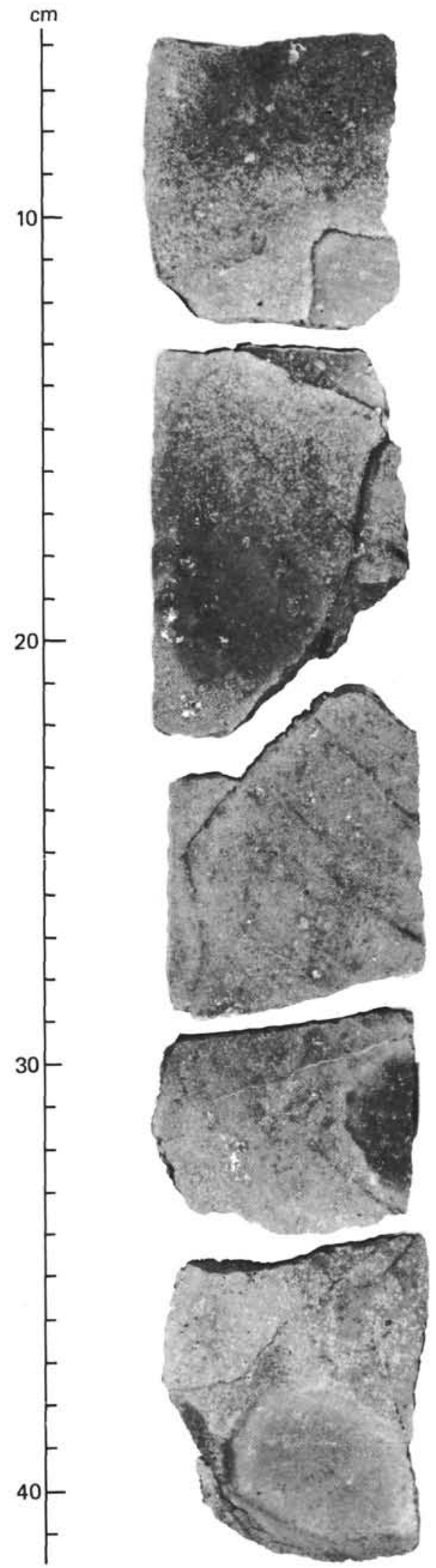

Figure 12. Five consecutive recovered pieces, Hole 456, Section 16-1, Pieces 7A-7E. Note vugs and vesicles filled with secondary minerals, mainly opal and quartz (gives light color). Note sedimentary inclusion near bottom. 


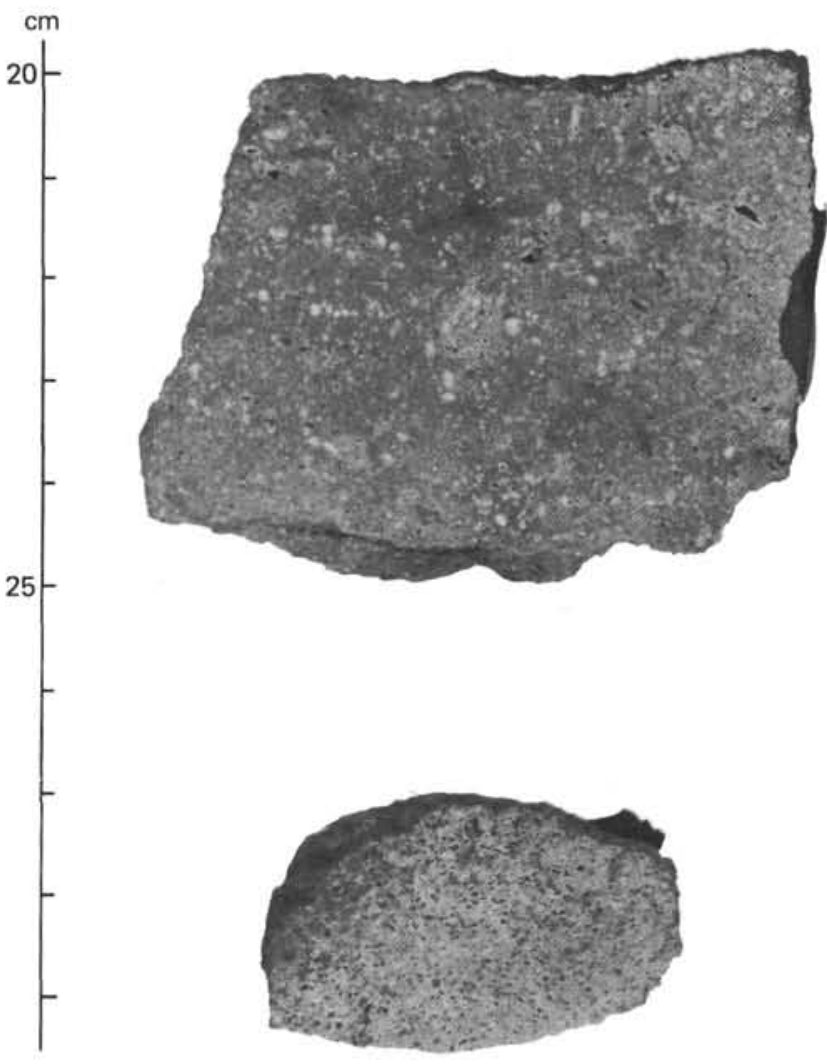

Figure 13. Recrystallized calcareous tuff and mudstone, Hole 456, Section 16-1, Pieces 2 and 3. The lower piece contains clay minerals, quartz, and wairakite, a zeolite-like mineral indicative of high temperatures of alteration $\left(>200^{\circ} \mathrm{C}\right.$; Natland and Hekinian, this volume).

In Hole 456A, recovery in this unit was limited to seven pieces of slightly vesicular, moderately altered basalt. None is glassy.

\section{Petrography}

The rocks of this unit are highly vesicular (up to $30 \%$ vesicles) aphyric to sparsely phyric basalts with subophitic to intersertal texture. Tabular plagioclase $(1-2 \%)$ and rare anhedral clinopyroxene are the microphenocrysts. Some rocks have large vesicles (up to $1 \mathrm{~cm}$ diameter), but the more typical basalts have vesicles $0.2-2 \mathrm{~mm}$ in diameter. In Core 15 of Hole $456 \mathrm{~A}$, the vesicles are tear-shaped and lined with glassy and spherulitic segregations. The basalts contain about 3 percent olivine (as granular and skeletal crystals, 0.3$0.5 \mathrm{~mm}$ in size, $\mathrm{Fo}_{85}$ ), 40 percent plagioclase (as laths and skeletal microlites up to $1 \mathrm{~mm}$ long; ca. $\mathrm{An}_{60-65}$ ), $30-40$ percent skeletal to dendritic clinopyroxene $(0.1-$ $0.3 \mathrm{~mm}$ in size), about 2 per cent dust-like opaque minerals, and $15-25$ percent altered interstitial glass containing minute fibrous dendrites of what is most probably clinopyroxene (too small to identify optically).

Three types of vesicles occur in these basalts. The most abundant are small (0.1- to 0.3-mm-diameter), irregular vesicles dispersed throughout the rocks in intersertal patches between skeletal plagioclase and clinopyroxenes. The second type are large, spherical

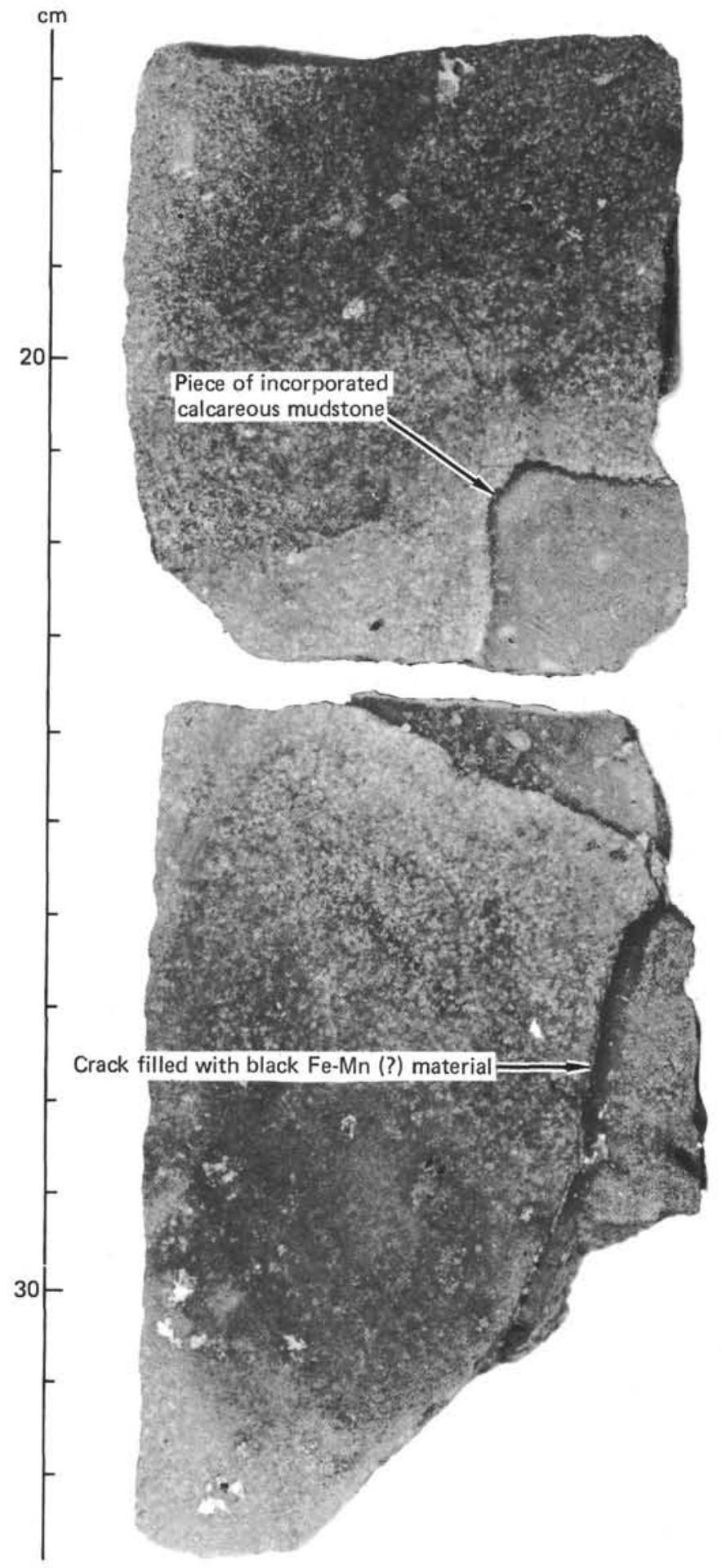

Figure 14. Detail of two pieces in Figure 12, showing sedimentary rocks included in hydrothermally altered basalt. A crack filled with earthy black secondary minerals ( $\mathrm{Fe}-\mathrm{Mn}$ oxides?) may represent an earlier stage of hydrothermal activity at the site. 
cavities up to $1 \mathrm{~cm}$ in diameter. These occur in subophitic rocks; however, the texture of the rocks immediately adjacent to the vesicles is aspherulitic. It appears that expansion of the gas which formed the vesicles may have cooled the rock sufficiently to cause spherulites. The third type of vesicle occurs in nearglassy rims to larger vesicles. These near-glassy linings in fact have fibrous spherulites within them; some have abundant tiny titanomagnetite crystals. The vesicles in these linings are round and evenly dispersed. They are typically less than $0.1 \mathrm{~mm}$ in diameter.

Unit $B_{A}$ (Core 12, Pieces 1-4; Core 13, Piece 2; Core 14, Pieces 1 and 2; Core 15, Piece 1, all in Hole 456A)

\section{Lithology}

This unit consists of fine-grained plagioclase-phyric, sparsely vesicular basalt, with several pieces showing distinctive reddish alteration rinds. None of the pieces is glassy. We infer those at the tops of Cores 13, 14, and 15 to have fallen down the hole from its actual interval represented by Core 12 . The plagioclase phenocrysts are up to $0.8 \mathrm{~cm}$ in diameter.

\section{Petrography}

These basalts are highly plagioclase-phyric, containing up to 20-30 per cent of large (1- to 8-mm) euhedral phenocrysts and glomerocrysts of zoned labradorite (ca. $\mathrm{An}_{70-75}$ ). These are set in a near-spherulitic groundmass with approximately equal amounts of skeletal plagioclase microlites and clinopyroxene dendrites. Many of the glomerocrysts and phenocrysts are rounded, and a few isolated phenocrysts have fretted edges and pitted interiors. These all suggest that many of the crystals have been partially resorbed. The abundance of phenocrysts and glomerocrysts in the basalts probably reflects an accumulative process such as plagioclase flotation or sinking, or flowage differentiation. The resorption indicates that the crystals were not in equilibrium with their surrounding liquid upon extrusion, but they might have been at higher pressures. They appear to be resorbing from euhedral rather than irregular, edges, and hence are probably not xenocrysts.

A single pseudomorph after an olivine phenocryst is in the thin section prepared from these rocks. It appears to be made up of clays and $\mathrm{Fe}$ oxides. It has been partially replaced by carbonate and originally was skeletal, embayed with glassy material texturally similar to the groundmass.

\section{Unit $B_{B}$ (Core 12, Pieces 6-13 and Core 13, Hole 456A)}

\section{Lithology}

The few basalts recovered of this type are moderately to intensely altered, but locally fresh, aphyric vesicular basalts. Alteration is to grayish brown hues, which contrast with darker gray fresh zones. The lowest piece of Core 13 has a rim of fresh glass. Overall, these basalts are more vesicular than those in Units $B_{1}$ and $B_{2}$.

\section{Petrography}

The single thin section made from basalts of this unit has a subophitic texture and consists of 3 percent olivine, 38 percent plagioclase $\left(\mathrm{An}_{60-65}\right), 24$ percent clinopyroxene, $<1$ per cent titanomagnetite, and 5 percent devitrified glass. The glass is partially altered to palagonite. Round to irregular vesicles make up 30 percent of the section; some are lined or filled with smectite or palagonite.

\section{ALTERATION}

Although only 35.5 meters of basalt was penetrated at Hole 456, and 45 meters at Hole 456A, both holes exhibit a diversity in the extent and type of alteration unusual in such short basaltic sections. In both holes, alteration diminishes sharply with depth. At the top of both holes alteration appears to have occurred under non-oxidative conditions. In the lower basalt cores of the two holes, however, alteration was distinctly oxidative, and sulfides are absent. The alteration in Hole 456 was so striking that Hole $456 \mathrm{~A}$ was drilled in part to evaluate the local variability of alteration in the basement rocks.

The general features of the alteration appear to reflect the interaction of basaltic rocks with hydrothermal solutions leaving the basement. The effects appear to be more pronounced in Hole 456 than in Hole 456A, since the zone of intense alteration is thicker.

A variety of evidence indicates that the altering solutions were hydrothermal:

1) A rather high heat flow value of $2.7 \mathrm{HFU}$ was obtained in Hole 456, whereas a considerably lower value of 1.1 HFU was obtained in Hole 456A, a scant 200 meters away. Local wide variability in heat flow would be expected to be associated with hydrothermal circulation of sea water within young oceanic (and inter-arc basin) crust.

2) Pyrite has been deposited in the uppermost basalts and in interbedded (and incorporated) sediments.

3) The basalts have been transformed to greenschistfacies metabasalts, rich in chlorite and epidote (Natland and Hekinian, this volume).

4) The lowest sediments in Hole 456 have been recrystallized to an assemblage of clay, quartz, and wairakite (Natland and Hekinian, this volume), suggesting that temperatures in excess of $200^{\circ} \mathrm{C}$ were reached.

5) Hydrogenous iron and manganese-rich sediments or encrustations were recovered in Core 17 of Hole 456. The dark reddish gray material is similar to crack fillings in Section 16-1 of the same hole, and these both resemble $\mathrm{Fe}-\mathrm{Mn}$ deposits in areas of known sea-floor hydrothermal activity such as fracture zone A of the FAMOUS area (Hoffert et al., 1978), and the Galapagos Mounds Hydrothermal Field (Lonsdale, 1977; Hekinian et al., 1978; Natland et al., 1979).

6) The basal sediments in Holes 456 and $456 \mathrm{~A}$ are reddish in color. Although they contain a considerable volcaniclastic component, the color is probably because 
they contain a ferruginous (and manganous?) component similar to basal sediments on the East Pacific Rise (Boström and Peterson, 1966) and drilled from its flank (Cronan, 1973). Both types of deposits are inferred by these authors to be hydrothermal in origin.

7) There is a high, and variable heat flow in the vicinity of Site 456 (Hobart et al., 1979), almost certainly because of present-day hydrothermal flux.

Overall, then, hot solutions rich in $\mathrm{Fe}, \mathrm{Si}, \mathrm{Mn}, \mathrm{Mg}$, and $\mathrm{S}$ have permeated these rocks at one time or another. Site 456 is the first place where basement rocks have ever been drilled that show such marked effects of hydrothermal activity on basalts.

The strongest alteration-and the firmest indications of high temperatures of alteration-occurs in the very lowest sediments and uppermost basalts. It seems plausible that the sediments formed an impermeable cap to basement, below which hot hydrothermal fluids could flow in the permeable basalts. We cannot say whether there was more than one pulse of such solutions, perhaps explaining the two types (oxidative and non-oxidative) alteration in the basalts, or whether alteration occurred at one time, with a strong oxidation gradient downward. Some hydrothermal activity prior to the basalt alteration seems required to explain the ferruginous basal sediments and clay-rich $\mathrm{Fe}-\mathrm{Mn}$ sediments interbedded with the basalts.

\section{Igneous Rock Chemistry}

Wood et al. (this volume) report five analyses of basalts from Hole 456 and seven from Hole 456A. On the basis of these analyses, a complex chemical stratigraphy can be deduced for these short-penetration holes (Fig. 9). In all, two chemical units are present in Hole 456, and four in Hole 456A. The two in Hole 456 correlate with the upper and lower unit in Hole 456A and are labeled $B_{1}$ and $B_{2}$ on Figure 9. The two remaining chemical types in Hole $456 \mathrm{~A}$ are labeled $\mathrm{B}_{\mathrm{A}}$ and $\mathrm{B}_{\mathrm{B}}$. $B_{A}$ is a strongly plagioclase-phyric basalt, the only porphyritic basalt recovered in either hole. Its chemistry appears to reflect accumulation of plagioclase (i.e., high $\mathrm{CaO}$ and $\mathrm{Sr}$ ) and some olivine (high $\mathrm{Ni}$ ). Unit $\mathrm{B}_{\mathrm{B}}$ is very similar to $\mathrm{B}_{2}$, except that it has higher $\mathrm{Sr}$ and lower $\mathrm{Cr}$, $\mathrm{Ni}$, and $\mathrm{MgO}$. $\mathrm{TiO}_{2}$ and $\mathrm{Zr}$ are about the same in the two units.

Wood et al. (this volume) note that most of the basalts at Site 456 have the major-oxide and traceelement chemistry of depleted mid-ocean ridge basalts (N-type MORB). However, Unit $\mathrm{B}_{\mathrm{A}}$ (the porphyritic basalt) and $B_{B}$ have some of the trace element characteristics of island-arc tholeiites. This may explain why $B_{B}$ in particular is so vesicular. Apparently, two distinct magma sources were available to erupt lavas in this complex sequence at Site 456.

In comparison with Site 454 basalts, those at Site 456 are generally more evolved (with higher $\mathrm{TiO}_{2}$ and $\mathrm{Zr}$, lower $\mathrm{Ni}$ and $\mathrm{MgO}$ ).

The effects of alteration on basalt chemistry make full assessment of chemical stratigraphy difficult. In the non-oxidative, intensely altered uppermost basalts (mainly Unit $\mathrm{B}_{1}$ ), transformation of the basalts to pyritized, chlorite-rich greenschist-facies metabasites has reduced $\mathrm{CaO}$ in some samples by over 60 per cent and increased $\mathrm{MgO}$ by about 30 per cent. However, $\mathrm{K}_{2} \mathrm{O}$ only varies between 0.06 and 0.1 per cent in Unit $\mathrm{B}_{1}$ basalts, consistent with the predominant formation of secondary chlorite in these rocks. In the deeper basalts that underwent oxidative alteration, $\mathrm{K}_{2} \mathrm{O}$ reaches values between 0.40 and 0.98 per cent. $\mathrm{Rb}$ enrichment matches $\mathrm{K}_{2} \mathrm{O}$, ranging from 4-12 parts per million in these same basalts. In Unit $\mathrm{B}_{\mathrm{B}}, \mathrm{MgO}$ drops from 6.1 to 4.3 per cent as $\mathrm{K}_{2} \mathrm{O}$ and $\mathrm{Rb}$ increase. All of these changes probably reflect alteration of olivine and of glass to K-rich smectite. It appears then that formation of chlorite-rich and smectiterich alteration products had opposite geochemical effects. One can only speculate that the alteration might have been synchronous, with non-oxidative, high-temperature fluids moving along the sediment/basalt interface, mainly within the more permeable basement rocks. Below this zone of most intense flow, the fluids could have mixed with colder, more oxygen-rich fluids to produce a completely different type of alteration. Alternatively, two alteration events - the first oxidative, the second non-oxidative-may have occurred. In either case, the non-oxidative alteration appears to have been concentrated at the sediment/basalt interface.

\section{PALEOMAGNETISM}

Site 456 is located on a negative magnetic anomaly, presumably between Magnetic Anomalies 2 (Olduvai event) and 2A (Gauss normal epoch). Only sediments below 60-meter sub-bottom depth in Holes 456 and $456 \mathrm{~A}$ and basaltic basement rocks in Hole 456 were suited for paleomagnetic measurements. All sediments studied in both holes ( 1.6 to $1.8 \mathrm{~m}$.y. in biostratigraphic age), except two samples in Hole 456A, have positive inclination, whereas basement rocks (Hole 456) are reversed. The values of inclination in both cases are in agreement with the absolute value of the present geomagnetic field inclination. For more details, see Bleil (this volume).

\section{PHYSICAL PROPERTIES}

Compressional wave velocity, wet-bulk density, saltcorrected water content, porosity, and acoustic impedance were determined from cores recovered from Site 456. The measurements are tabulated in Table 2. Velocity-density parameters for both holes are plotted against depth in Figure 15.

\section{Sonic Velocities}

Sonic velocities for the vertical direction were measured in the Hamilton Frame. The results for Holes 456 and $456 \mathrm{~A}$ were essentially the same as can be seen in the velocity-depth plot in Figure 15 . The top 56 meters of the sedimentary column, consisting of oozes and vitric muds, was unlithified and yielded velocities in the range $1.53-1.61 \mathrm{~km} / \mathrm{s}$. From $56-78$ meters sub-bottom, the velocities averaged about $2.2 \mathrm{~km} / \mathrm{s}$, then from 78-meter to approximately 115 -meter depth averaged $1.95 \mathrm{~km} / \mathrm{s}$. The rocks below 56 meters were essentially the lithified equivalent of the soft sediments above- 
Table 2. Physical properties measurements, Holes 456 and 456A.

\begin{tabular}{|c|c|c|c|c|c|c|c|c|}
\hline $\begin{array}{c}\text { Sample } \\
\text { (Interval in } \mathrm{cm} \text { ) }\end{array}$ & $\begin{array}{l}\text { Depth } \\
(\mathrm{m})\end{array}$ & $\begin{array}{c}\text { Sound } \\
\text { Velocity } \\
\text { (vertical) } \\
(\mathrm{km} / \mathrm{s})\end{array}$ & $\begin{array}{c}\text { GRAPE } \\
\text { 2-minute } \\
\text { Wet-Bulk } \\
\text { Density } \\
\left(\mathrm{g} / \mathrm{cm}^{3}\right)\end{array}$ & $\begin{array}{c}\text { Water } \\
\text { Content } \\
\text { (salt- } \\
\text { corrected) } \\
(\%)\end{array}$ & $\begin{array}{l}\text { Porosity } \\
\left(\sigma^{a} \%\right)\end{array}$ & $\begin{array}{l}\text { Wet-Bulk }{ }^{b} \\
\text { Density } \\
\left(\mathrm{g} / \mathrm{cm}^{3}\right)\end{array}$ & $\begin{array}{c}\text { Acoustic } \\
\text { Impedance } \\
\left(\mathrm{g} / \mathrm{cm}^{2} \mathrm{~s} \times 10^{5}\right)\end{array}$ & $\begin{array}{l}\text { Rock } \\
\text { Type }\end{array}$ \\
\hline \multicolumn{9}{|l|}{ Hole 456} \\
\hline $2-1,39-41$ & 0.89 & 1.55 & & 42.4 & 66.6 & 1.61 & 2.50 & Ooze \\
\hline $2-2,89-91$ & 2.89 & 1.56 & & & & & & Ooze \\
\hline $2-3,79-91$ & 4.29 & 1.59 & & 38.6 & 63.8 & 1.70 & 2.70 & Ooze \\
\hline $2-4,59-61$ & 5.59 & 1.57 & & & & & & Ooze \\
\hline $2-5,29-31$ & 6.79 & 1.60 & & 40.3 & 64.5 & 1.64 & 2.62 & Ooze \\
\hline $3 \cdot 1,89-91$ & 10.89 & 1.61 & & & & & & Ooze \\
\hline $4-1,90-91$ & 20.39 & 1.58 & & 36.6 & 61.0 & 1.71 & 2.70 & Ash \\
\hline $4-2,32-34$ & 21.32 & 1.55 & 1.67 & 39.3 & 63.8 & 1.66 & 2.57 & Ash \\
\hline $6-1,62-64$ & 39.12 & 1.55 & 1.47 & & & & 2.28 & Ooze \\
\hline $6-2,76-78$ & 40.76 & 1.53 & 1.45 & 52.4 & 75.6 & 1.46 & 2.23 & Ooze \\
\hline $7-1,67-69$ & 48.67 & 1.59 & 1.50 & & & & 2.39 & Vitric mud \\
\hline $7-2,53-55$ & 50.03 & 1.57 & 1.51 & 47.1 & 70.2 & 1.53 & 2.40 & Vitric mud \\
\hline $9-1,59-64$ & 67.59 & 2.27 & 1.64 & & & & 2.73 & Mudstone \\
\hline $10-1,30-32$ & 76.80 & 1.86 & 1.54 & 40.4 & 63.8 & 1.62 & 3.01 & Mudstone \\
\hline $10-3,30-33$ & 79.80 & 1.91 & 1.64 & & & & 3.13 & Mudstone \\
\hline $11-1,32-37$ & 86.32 & 1.98 & 1.72 & & & & 3.41 & Mudstone \\
\hline $12-1,3-5$ & 95.53 & 1.85 & 1.71 & 36.3 & 54.2 & 1.67 & 3.09 & Mudstone \\
\hline $13, \mathrm{CC}, 28-30$ & 105.28 & 1.98 & 1.82 & 28.8 & 50.9 & 1.81 & 3.58 & Siltstone \\
\hline $14-1,30-33$ & 114.80 & 2.09 & 1.93 & 24.3 & 45.9 & 1.93 & 4.01 & Sandstone \\
\hline $14, \mathrm{CC}, 11-13$ & 115.66 & 2.11 & 1.85 & 30.4 & 54.4 & 1.84 & 3.88 & Siltstone \\
\hline $16-1,23-28$ & 133.73 & 4.32 & 2.57 & & & & 11.10 & Altered basalt \\
\hline $16-1,90-92$ & 134.40 & 3.36 & 2.46 & 11.9 & 27.0 & 2.32 & 7.80 & Aitered basalt \\
\hline $16-2,103-105$ & 136.03 & 3.90 & 2.49 & 6.5 & 16.1 & 2.52 & 9.83 & Altered basalt \\
\hline $18-1,48-50$ & 152.98 & 3.79 & 2.50 & 9.6 & 23.2 & 2.48 & 9.40 & Altered basalt \\
\hline $18-1,22-27$ & 152.72 & 4.04 & 2.44 & & & & 9.86 & Altered ves, basalt \\
\hline \multicolumn{9}{|l|}{ Hole 456A } \\
\hline $1.5,10-12$ & 6.00 & 1.57 & & 39.2 & 63.0 & 1.65 & 2.59 & Mud \\
\hline $1.7,35-37$ & 7.95 & 1.60 & & & & & & Clay \\
\hline $3-2,40-42$ & 39.90 & 1.58 & 1.66 & 43.6 & 67.2 & 1.58 & 2.50 & Clay \\
\hline $5-1,98-100$ & 57.98 & 2.03 & 1.57 & 44.9 & 68.3 & 1.56 & 3.17 & Mudstone \\
\hline $5-2,15-17$ & 58.65 & 2.40 & 1.75 & 35.2 & 59.1 & 1.72 & 4.13 & Mudstone \\
\hline $6-1,26-28$ & 66.76 & 2.15 & 1.63 & 40.0 & 63.9 & 1. 64 & 3.53 & Mudstone \\
\hline $6 \cdot 3,8-10$ & 69.58 & 2.46 & 1.99 & 25.2 & 48.0 & 1.95 & 4.80 & Sandstone \\
\hline $7-1,63-68$ & 76.63 & 2.17 & 1.77 & & & & 3.84 & Mudstone \\
\hline $7-2,62-64$ & 78.12 & 2.12 & 1.60 & 41.9 & 64.6 & 1.58 & 3.35 & Mudstone \\
\hline $8-1,125-127$ & 86.75 & 1.81 & 1.64 & 39.5 & 63.4 & 1.65 & 2.99 & Mudstone \\
\hline $9-1,31-33$ & 95.31 & 1.88 & 1.68 & 38.2 & 62.5 & 1.68 & 3.16 & Mudstone \\
\hline $9-2,28-31$ & 96.78 & 1.84 & 1.59 & & & & 2.93 & Mudstone \\
\hline $9-2,143-145$ & 97.93 & 2.0 & 1.70 & 31.7 & 53.3 & 1.72 & 3.44 & Sandstone \\
\hline $10-1,58-60$ & 105.08 & 2.03 & 1.79 & 32.5 & 56.6 & 1.78 & 3.61 & Siltstone \\
\hline $10-3,58-63$ & 108.08 & 1.91 & 1.73 & & & & 3.30 & Mudstone \\
\hline $11-1,29-31$ & 114.29 & 3.46 & 2.11 & & & & 7,30 & Limestone \\
\hline $12-1,3-5$ & 123.53 & 3.82 & 2.51 & & & & 9.59 & Plagioclase basalt \\
\hline $12-1,69-71$ & 124.19 & 3.98 & 2.23 & & & & 8.88 & Vesicular basalt \\
\hline
\end{tabular}

vitric mudstones, tuffs, and chalks with some sandstone and siltstone components. There was no obvious explanation in rock type for the high velocities observed between 56 and 78 meters in the column.

The highest velocity found among the sedimentary rock samples was $3.46 \mathrm{~km} / \mathrm{s}$ for a limestone taken from just above the basalts at Hole 456A $(11-1,29-31 \mathrm{~cm})$. Sonic velocities in the basalts ranged from 3.36 to 4.32 $\mathrm{km} / \mathrm{s}$.

\section{Density and Acoustic Impedance}

Wet-bulk densities of selected samples were determined by both 2-minute GRAPE counts and the gravimetric method. The average discrepancy between the two methods at this site is $0.03 \mathrm{~g} / \mathrm{cm}^{3}$ for measurements on 21 samples. Although a few density measurements on samples from 56-78 meters sub-bottom are higher than the general trend, the density plot does not reflect the velocity plot in this depth range but essentially shows a gradual increase with the depth.

The acoustic impedance of the sedimentary rock is rather uniform, although a reflecting horizon might be identified at 56 meters sub-bottom. This corresponds to 70-millisecond two-way travel time below the bottom. No obvious reflector is apparent at that depth on the many reflection profiles across the small pond in which Site 456 is located. However, as seen in Figure 4, all subbottom reflectors at Site 456 are obscured by echoes from the bathymetric high surrounding the pond. A much more prominent reflection should be generated at 115 -meters sub-bottom (130-ms, two-way travel time below the bottom) where the impedance increases abruptly just above the basalt. This corresponds to the deepest reflections obtained from the pond, but again no prominent reflector can be identified.

\section{Thermal Conductivity}

As with the previous sites of Leg 60, the thermal conductivity of soft sediments was measured by both the QTM and the needle probe, and that of semilithified and fully lithified sediment and basement rock by the QTM. A high rate of increase in sediment thermal conductivity with depth $\left(0.6 \mathrm{mcal} / \mathrm{cm} \mathrm{s}^{\circ} \mathrm{C}\right) / 100$ meters was observed at this site. For the basement rocks, it was found that altered basalts have slightly higher thermal conductivity than unaltered basalts. For more details, see Horai (this volume).

\section{HEAT FLOW}

Heat flow values estimated from temperature measurements at sub-bottom depths of 29.0 meters (Hole 456 ) and 47.5 meters (Hole 456A) are $2.71 \mathrm{HFU}$ (possible range 2.1-3.2 HFU) and 1.06 HFU (possible range 0.9-1.2 HFU), respectively. Such a marked difference in heat flow at sites only 200 meters apart can be explained only by the existence of local hydrothermal systems in the upper crust. Details of the measurements are given in Uyeda and Horai (this volume). 


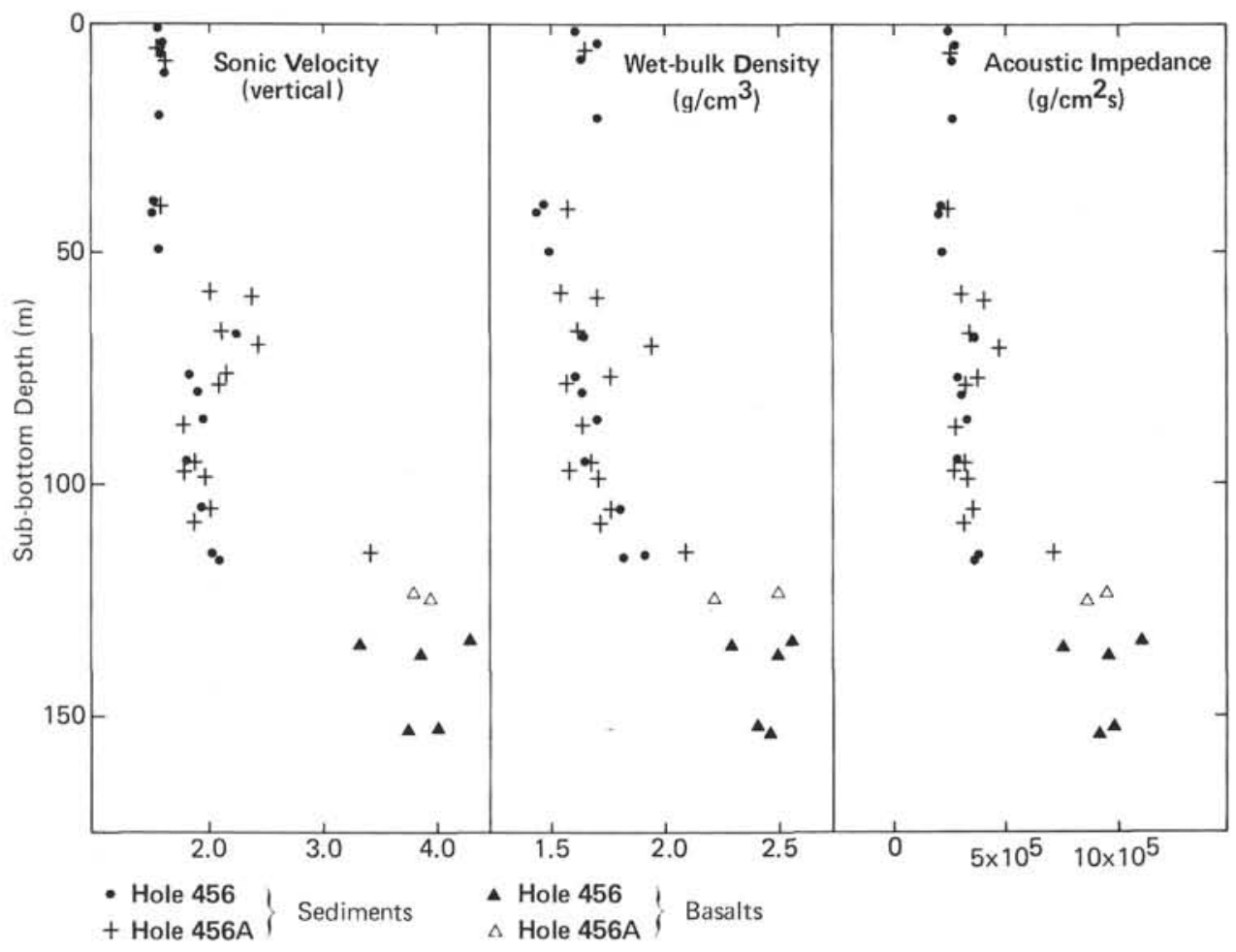

Figure 15. Physical properties versus depth, Site 456.

\section{SUMMARY AND CONCLUSIONS}

The objectives at Site 456 were the same as at Site 455 (survey target SP-4D); that is, to sample the crust and acquire data relevant to the evolutionary history of the Mariana Trough at an intermediate distance from the spreading axis (see Mariana Trough Background and Objectives chapter, this volume).

To avoid the coarse bottom-transported volcanic sand that caused the drilling problems at Site 455 , we located Site 456 in a small sediment pond perched on a bathymetric high. Hole 456 penetrated 134 meters of sediment and 35 meters of a very complex basaltic basement which showed strikingly strong alteration, suggestive of localized hydrothermal activity. To test the lateral extent of this alteration and attempt deeper penetration into less altered basement, a second hole (Hole 456A) was drilled as far as possible from Hole 456 ( $200 \mathrm{~m}$ to the east) within the same pond. Hole 456A penetrated 118 meters of sediment and 41 meters into the igneous basement.

The sediment columns in both holes were very similar. The deeper half of the sediments were rapidly deposited in the early Pleistocene. The deepest microfossils, which are several meters above igneous basement, are of the Emiliania annula Subzone, with an age of 1.6-1.8 m.y.

The assignment of a crustal age to Site 456 requires determining the age relationship of the sediments and basement. The paleontologic age date of 1.6-1.8 m.y. is a reliable minimum for the crustal age. However, the paleomagnetic data somewhat cloud the picture. The survey by the Glomar Challenger en route to the site showed that it is on a negative magnetic anomaly which was identified as between Anomalies 2 and $2^{\prime}$ in the Matuyama reversed epoch. The identification is considered to be tentative, because site survey magnetic profiles to the north and the south of the Challenger profile do not show anomalies with good correlations to our data. If the Challenger anomaly sequence is caused by spreading, and is correctly identified, the age of the magnetic crust at the site is estimated to be $2.3 \pm 0.2$ m.y. The paleomagnetic inclinations (see Bleil, this volume for details on paleomagnetics) obtained in the basaltic basement at Hole 456 are all negative, which is in agreement with the surface anomaly. However, paleomagnetic inclinations in the Unit II sediments in Hole $456 \mathrm{~A}$ are uniformly positive during the rapid sedimentation period from 1.6 to $1.8 \mathrm{~m} . \mathrm{y}$. B.P. This relationship suggests that the basalts were emplaced prior to the influx of sediments, and that the age relationships support a crustal age of 2.1-2.5 m.y., as suggested by the surface anomaly pattern.

Some of the basal sediments recovered at Site 456 apparently were on the sea floor when the basalts were extruded, indicating that the sedimentation must have predated the final igneous activity. These sediments were partly incorporated into the basalt (Fig. 14). So, if the normally magnetized sediments predated the reversally magnetized basement rocks, the crustal age may match the oldest sediments. The basalts are then evidence of igneous activity occurring away from the spreading axis during the period of the reversed earth magnetic field (Matuyama epoch) before $1.6 \mathrm{~m} . \mathrm{y}$. B.P.

The estimated crustal age range (1.6-2.5 m.y.) at Site 456 gives a spreading rate range of $2.2-1.4 \mathrm{~cm} / \mathrm{y}$. These 
rates fall within the ranges of spreading rate estimates for the western side of the Mariana Trough, except for the age of the basal sediments at Site 453, which are relatively young and will require a maximum spreading rate of $2.4 \mathrm{~cm} / \mathrm{y}$. Within the uncertainties of the data, however, the results of the Trough drilling support a model of slow and fairly constant symmetric spreading in this back-arc basin.

The basement section cored at Site 456 is a complex sequence of extrusive flows including four distinct chemical types of basalt. Incorporated sediments in one of the flows in Hole 456 suggest that basalts were extruded into soft sediments. Although no interbedded sediments were recovered at Site 456 they could easily be there. Recovery was poor in both holes and we were not able to log Hole 456, so we could have missed soft beds. Furthermore, because we had problems with hole stability in the Site 456 basement, high pump pressures and bit weight were used while drilling, further lessening the chance of recovering interbedded sediments.

Since emplacement of the basalts, basement in both holes underwent extensive hydrothermal alteration. In both holes the basalt sediments were hydrothermally altered. Basalts in Hole 456 are somewhat more altered than in Hole 456A. The uppermost basalts in both holes are transformed to pyritized chlorite-rich metabasites, but by 25 meters into basement the basalts became increasingly fresh, fractured, and difficult to drill. The pattern of alteration suggests that the hydrothermal fluids flow in a narrow zone along the top of the basalts beneath the impermeable basement. The spatial variation of the hydrothermal flow is indicated by the somewhat more intense alteration in Hole 456, the difference in heat flow measured in the two holes $(2.7 \mathrm{HFU}$ in Hole 456 and $1.1 \mathrm{HFU}$ in Hole 456A), and by the high and highly variable heat flow recorded on the sediment surface of the pond area by Hobart et al. (1979).

The sediments in both holes are similar and show two distinct sedimentary environments. The deeper half (from $56 \mathrm{~m}$ sub-bottom to basement) was deposited very rapidly $\left(>35 \mathrm{~kg} / \mathrm{cm}^{2} / \mathrm{m} . y\right.$.), probably when Site 456 was in or near the axial spreading graben and was exposed to bottom-transported sediments from the volcanic arc.

The bathymetric highs on the eastern side of the present axial graben are $15-20 \mathrm{~km}$ from the center of the graben. Thus, the back-arc crust was probably somewhat less than a million years old when its surface was elevated to the position of the present-day highs on each side of the graben. At Site 456 the rate of sedimentation suddenly decreased to near zero (there may also be nondepositional or erosional hiatuses at this level) at 1.6 m.y. B.P., and remained low until 0.9 m.y. B.P. The crust at Site 456 would have been 0.5-1 m.y. old at this point, and the change in deposition rate may be a function of the relative elevation of the site as it moved from the spreading graben area. From then until now the site has been elevated relative to the surrounding arc sediment apron, so it has not been exposed to bottomtransported sediments.

From 0.9-0.3 m.y.B.P., the sediment accumulation rate increased to around $7 \mathrm{~km} / \mathrm{cm}^{2} / \mathrm{m}$.y. This time span was also one of increased sedimentation at Site 454 , and thus may be a reliable indication of a period of increased volcanic activity on the Mariana arc.

\section{REFERENCES}

Bostrom, K., and Peterson, M. N. A., 1966. Precipitates from hydrothermal exhalations on the East Pacific Rise. Econ. Geol., 61: $1258-1265$.

Bukry, D., 1975. Coccolith and silicoflagellate stratigraphy, northwestern Pacific Ocean, Deep Sea Drilling Project, Leg 32. In Larson, R. L., Moberly, R., et al.; Init. Repts. DSDP, 32: Washington (U.S. Govt. Printing Office), 677-701.

Cronan, D. S., 1973. Basal ferruginous sediments cored during Leg 16, Deep Sea Drilling Project. In van Andel, Tj. H., Heath, G. R., et al., Init. Repts. DSDP, 16: Washington (U.S. Govt. Printing Office), 605-608.

Hekinian, R., Rosendahl, B. R., et al., 1978. Hydrothermal deposits and associated basement rocks from the Galapagos Spreading Center. Oceanologica Acta, 1:473-482.

Hobart, M. A., Anderson, R. N., and Uyeda, S., 1979. Heat transfer in the Mariana Trough. EOS, 60:383.

Hoffert, M., Perseil, A., Hekinian, R., et al. 1978. Hydrothermal deposits sampled by diving saucer in transform fault " $\mathrm{A}$ " near $37^{\circ} \mathrm{N}$ on the Mid-Atlantic Ridge, FAMOUS area. Oceanol. Acta, 1:73-86.

Lonsdale, P., 1977. Deep-tow observations at the Mounds Abyssal Hydrothermal Field, Galapagos Rift. Earth Planet. Sci. Lett., 36:92-110.

Natland, J., Rosendahl, B. R., Hekinian, et al., 1979. Galapagos hydrothermal mounds: stratigraphy and chemistry revealed by deep-sea drilling. Science, 204:613-616.

Nigrini, C. A., 1971. Radiolarian zones in the Quaternary of the equatorial Pacific. In Funnel, B. M., and Riedel, W. R. (Eds.), The Micropaleontology of Oceans: London (Cambridge University Press), pp. 443-461. 


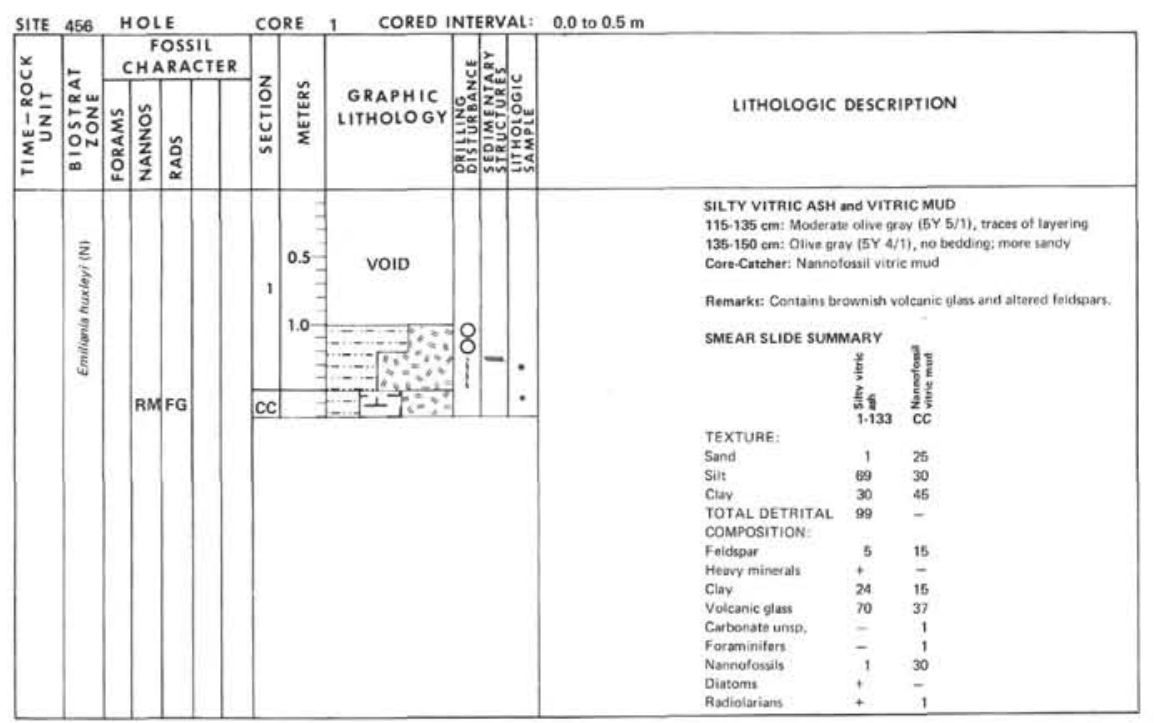

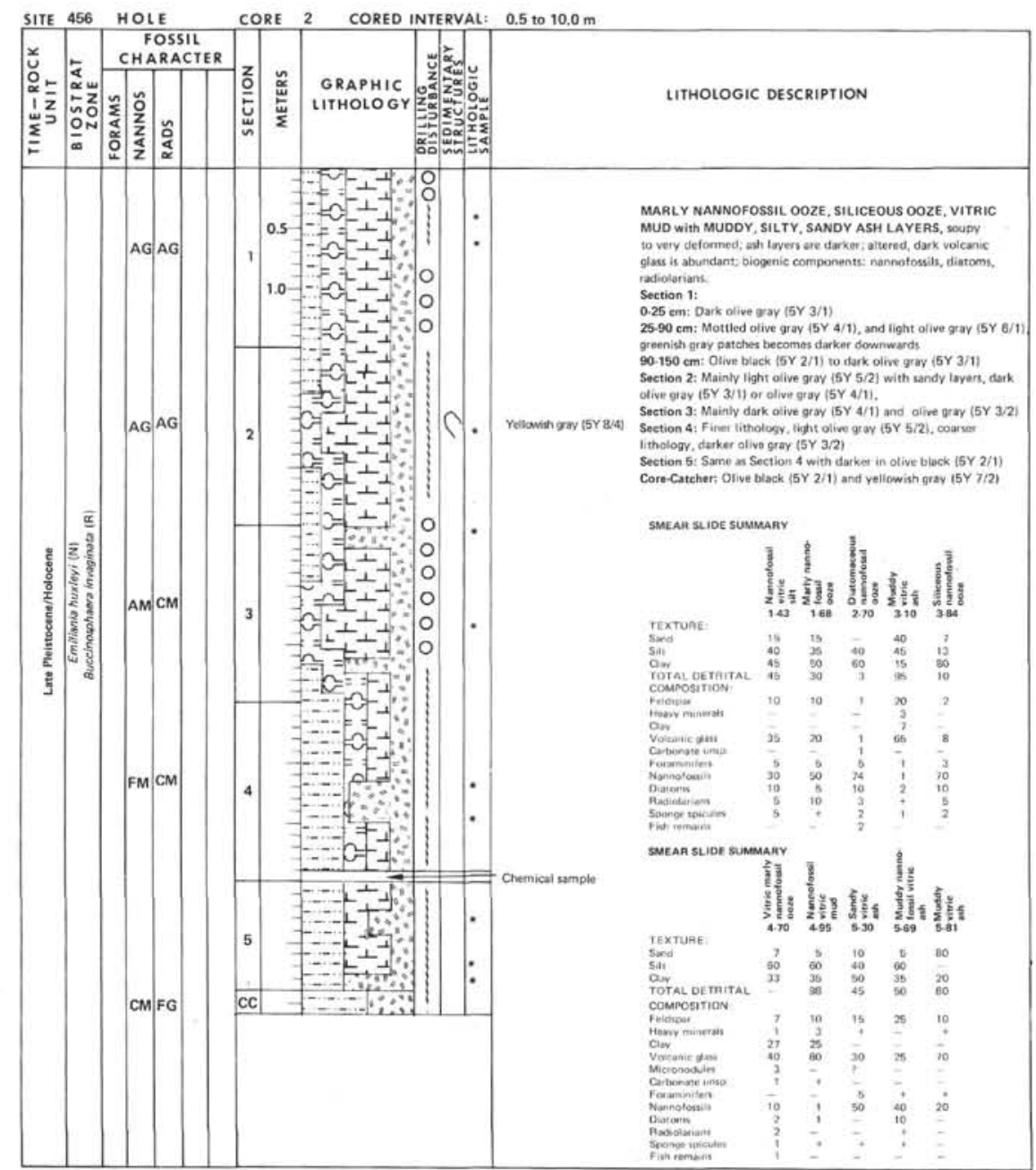




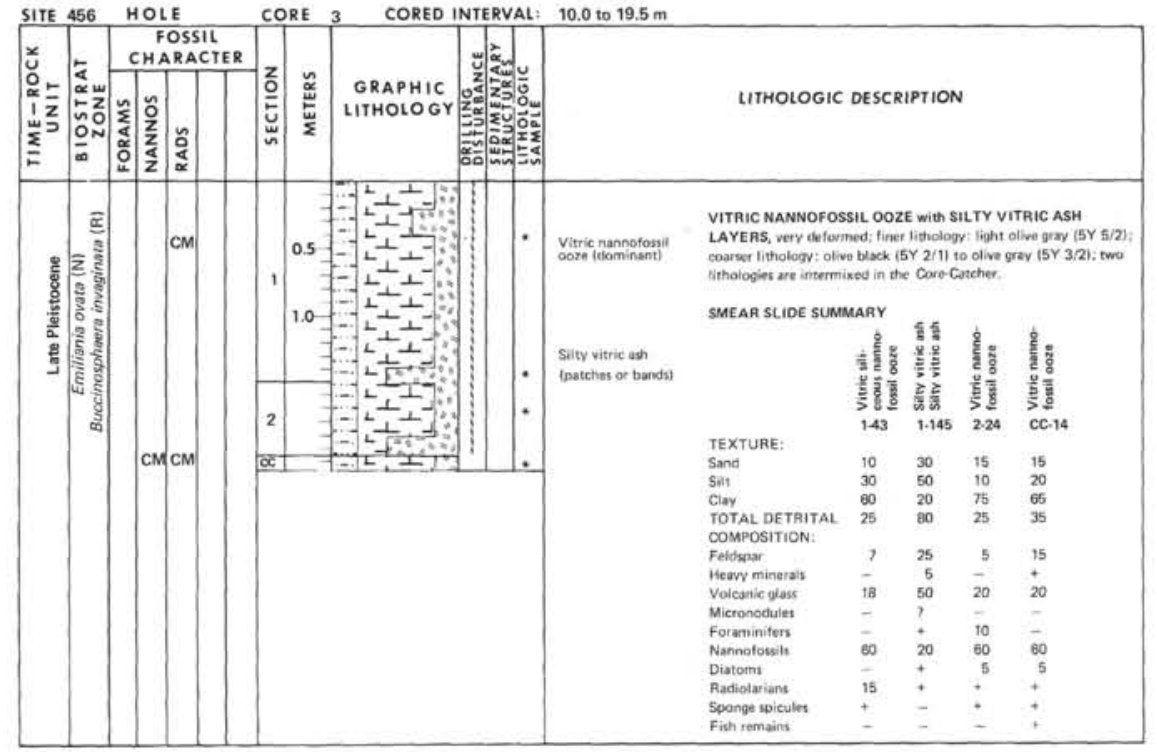

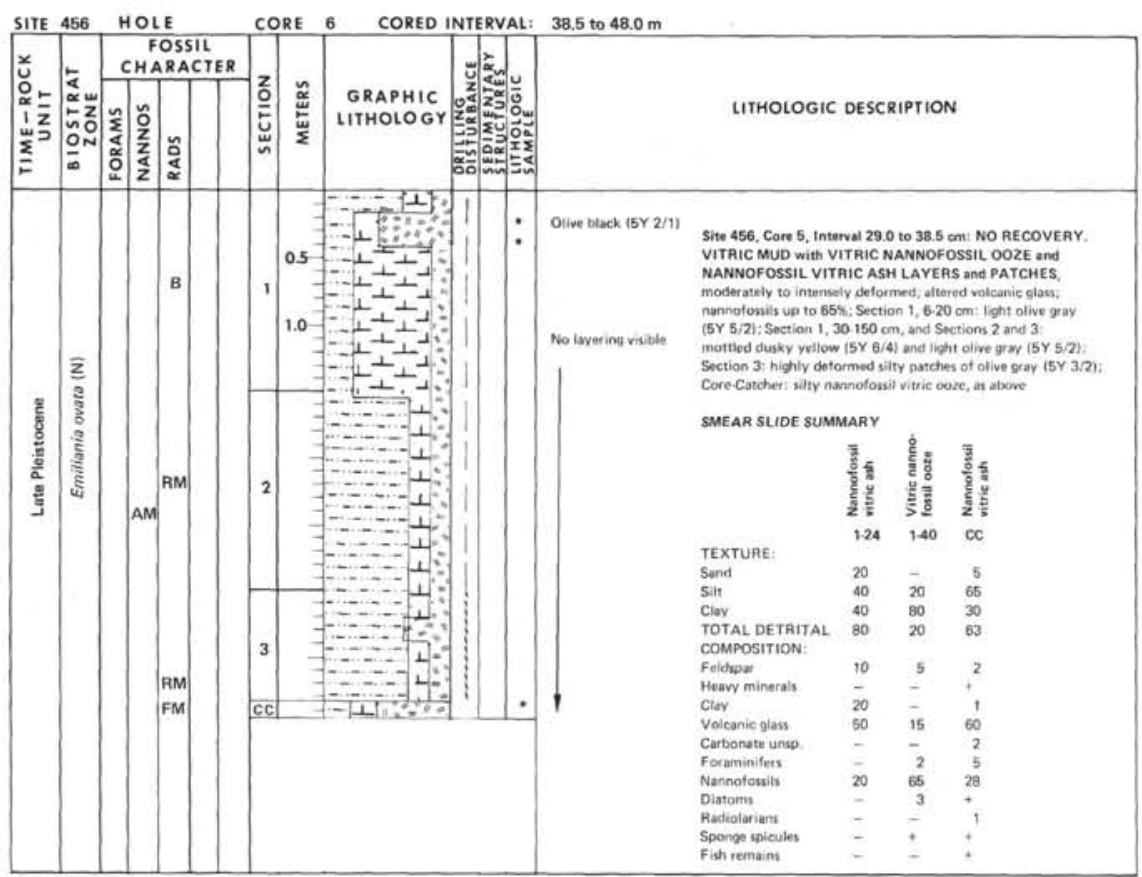

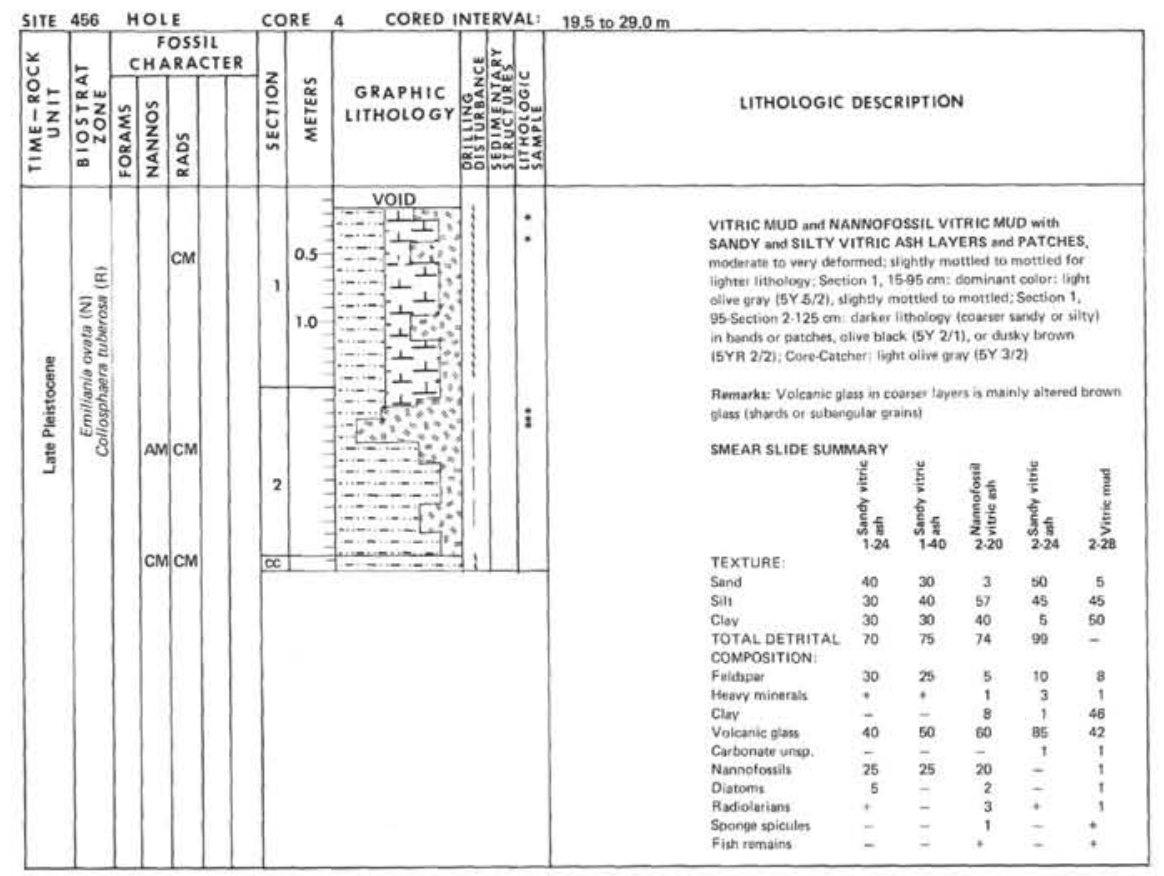

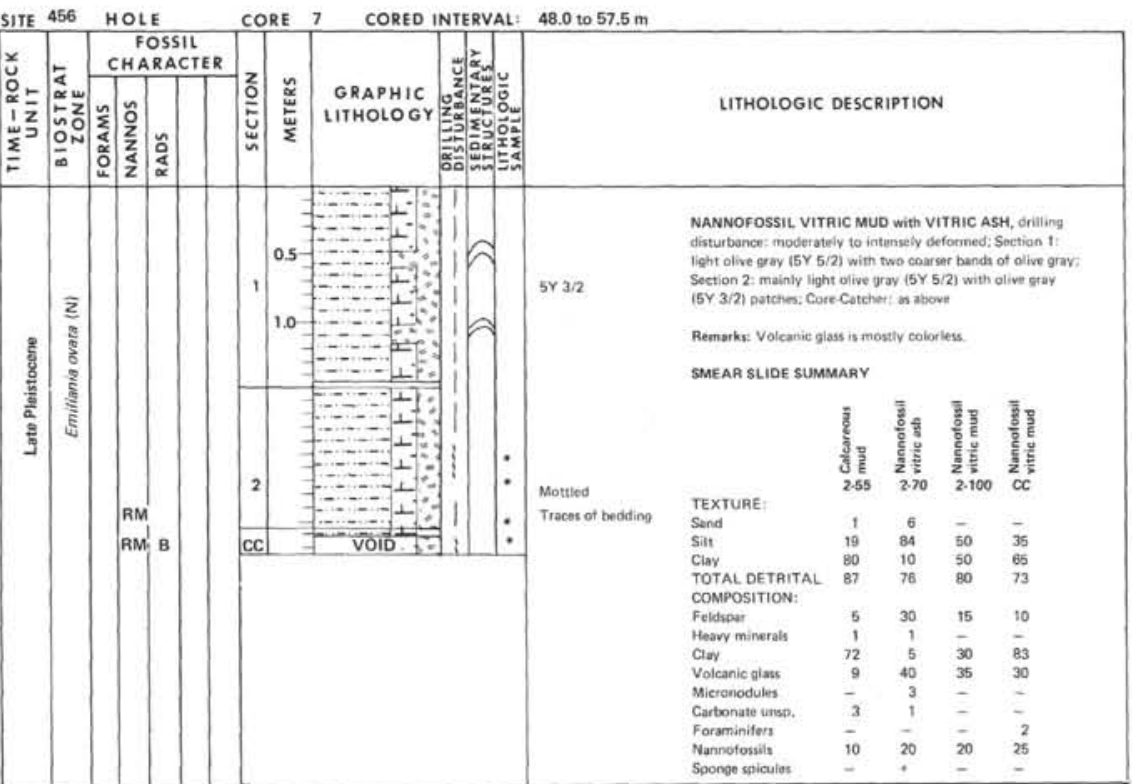



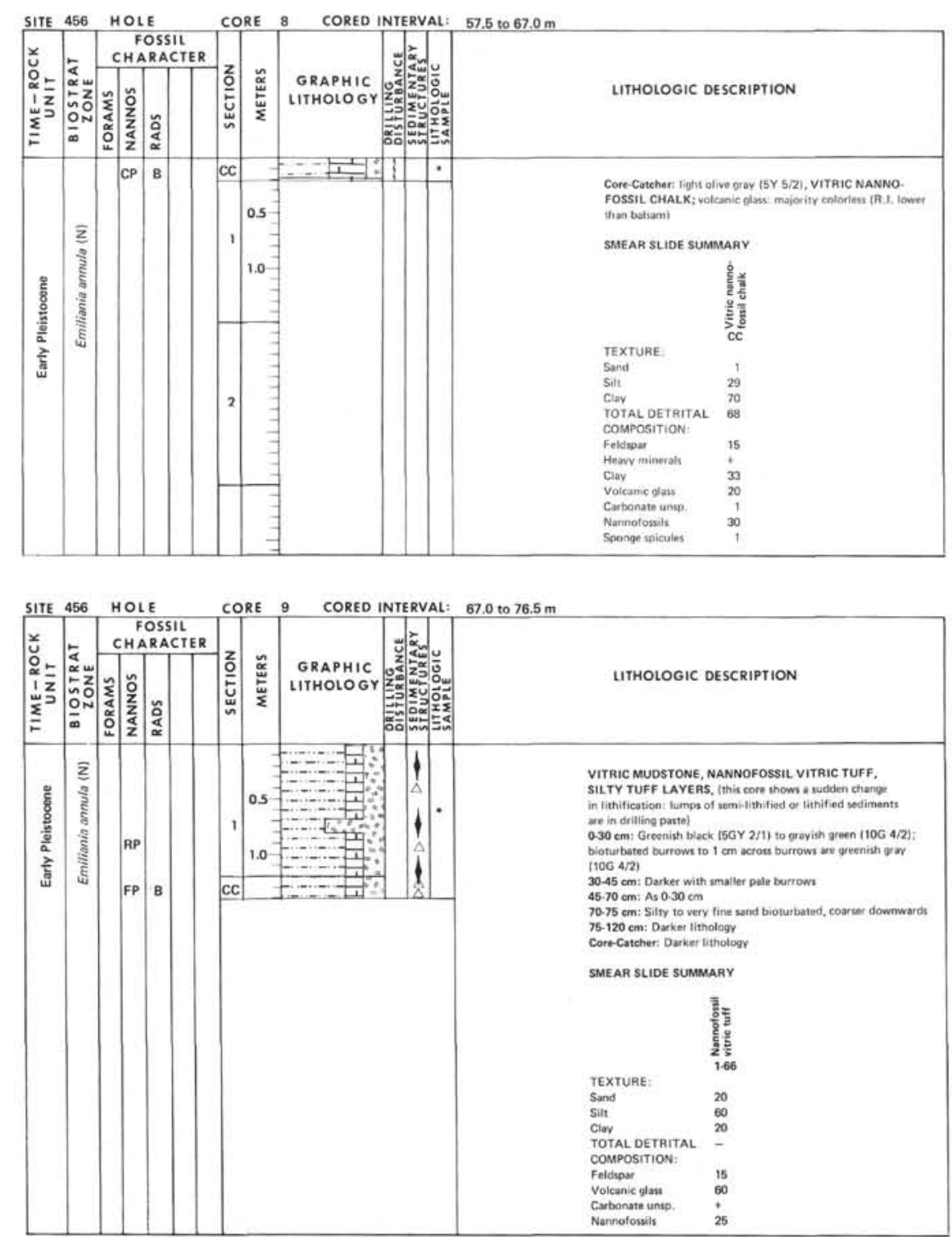

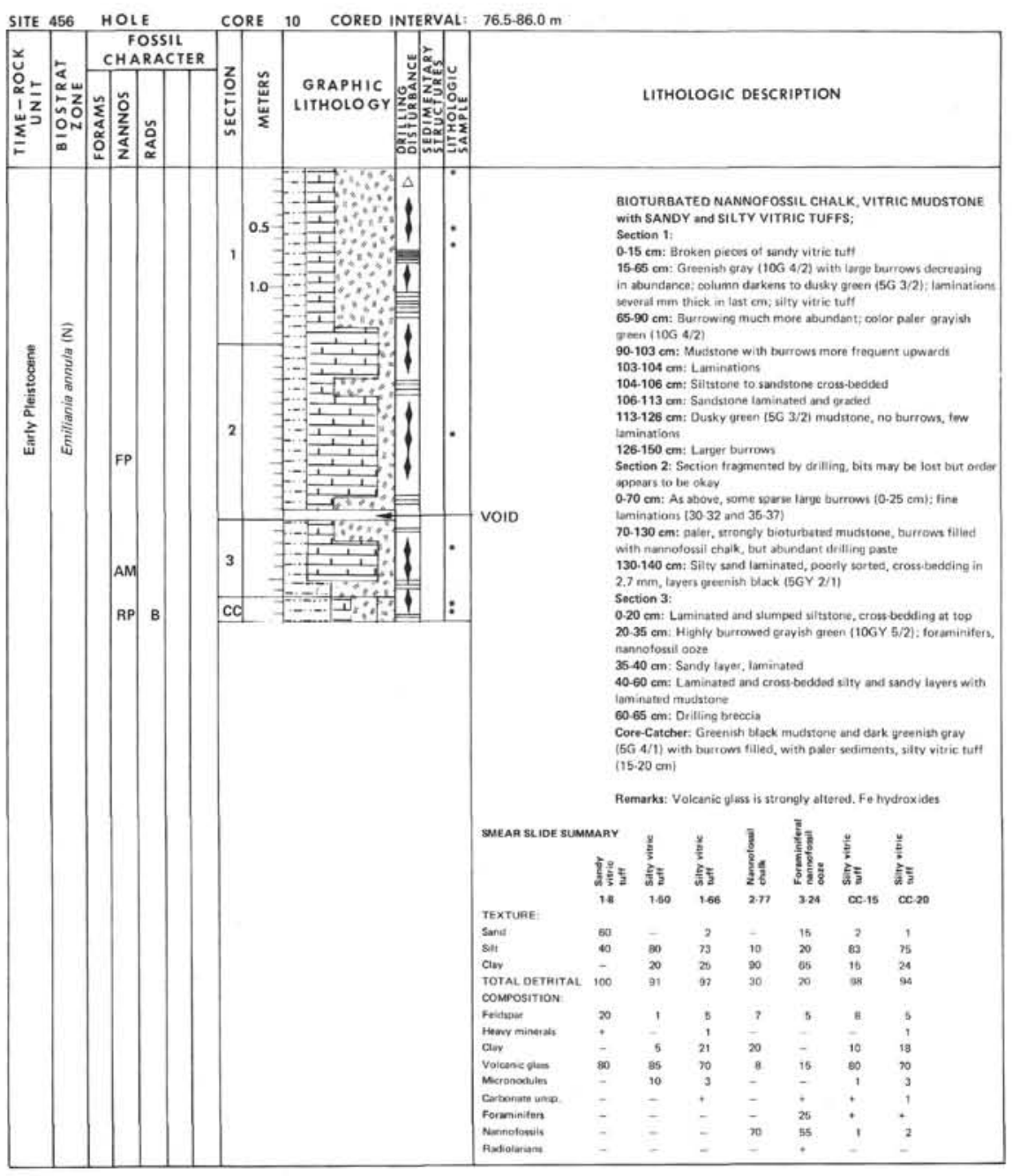




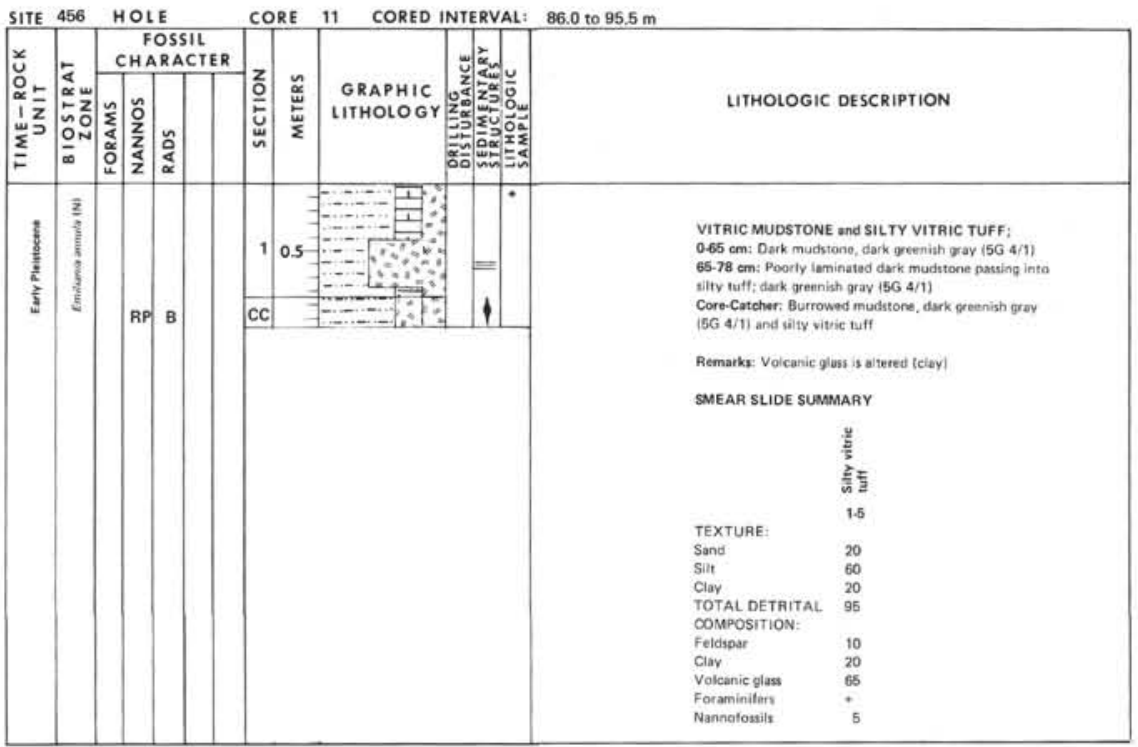

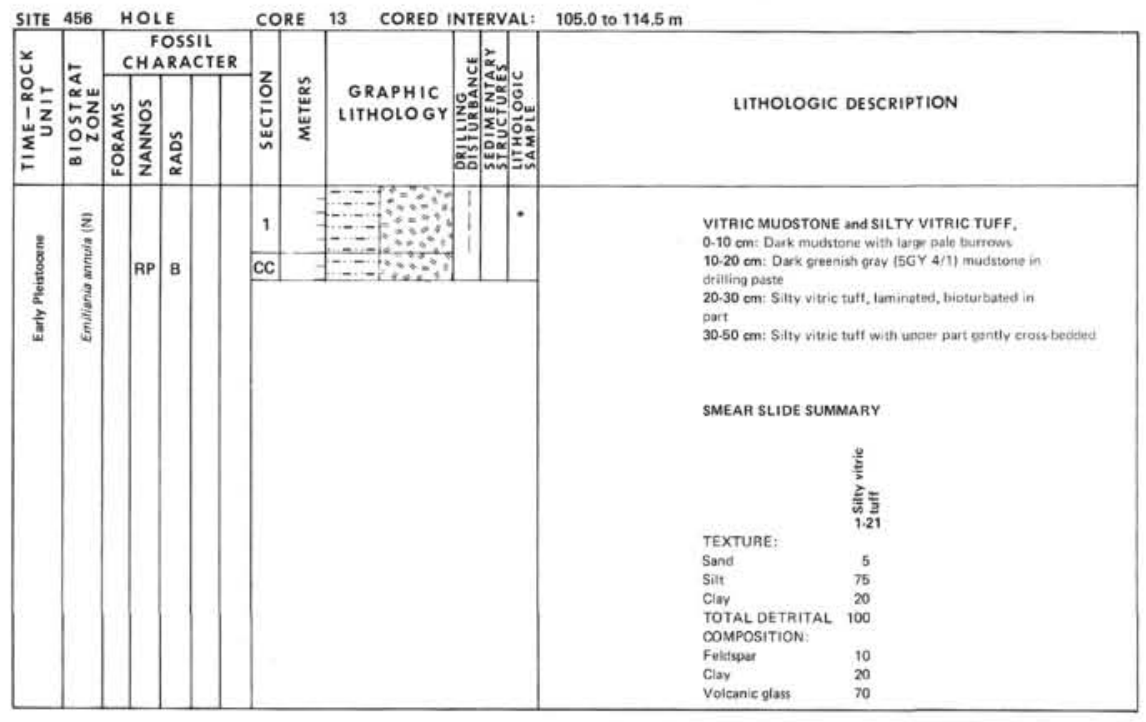

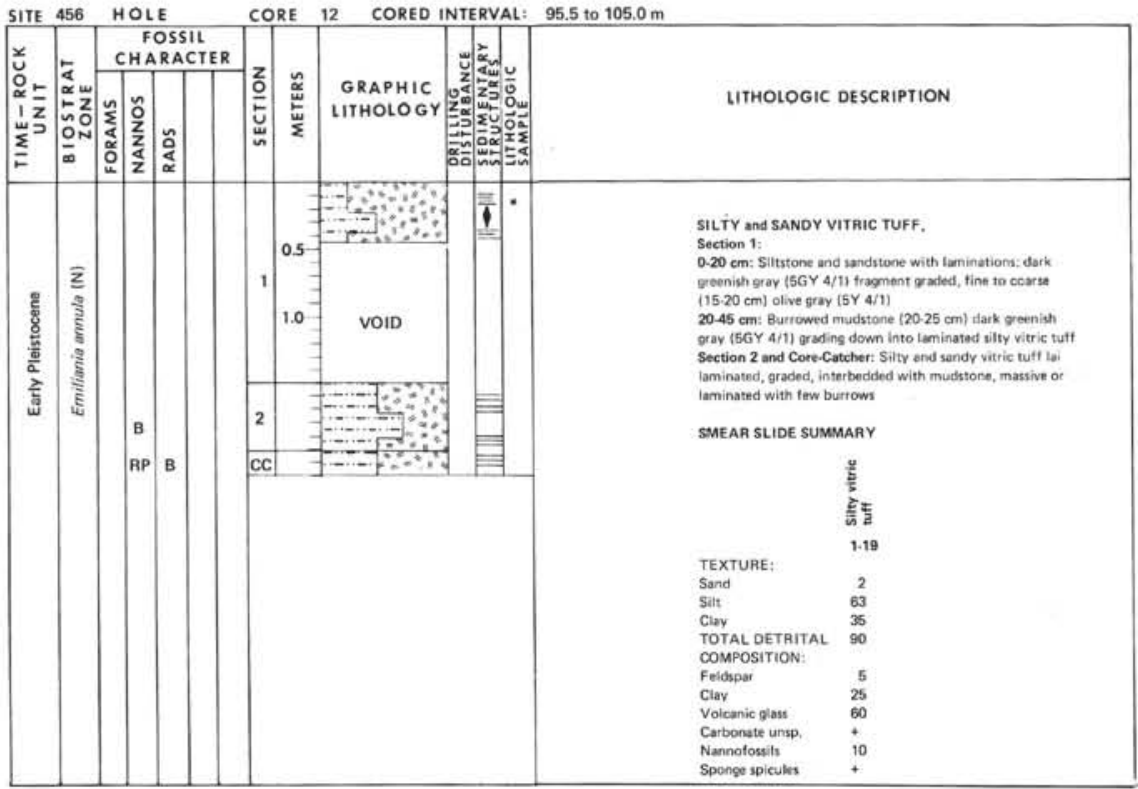

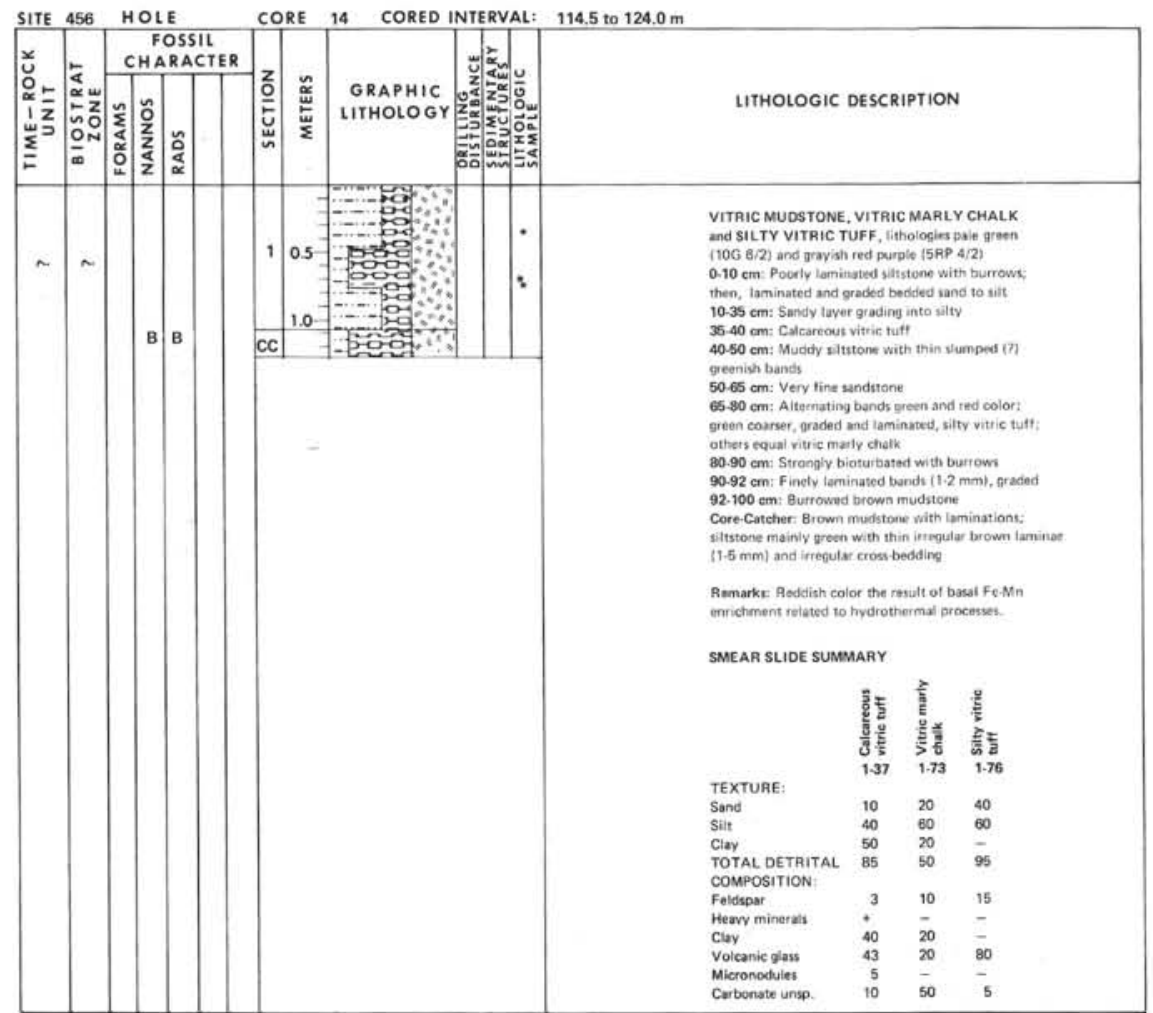




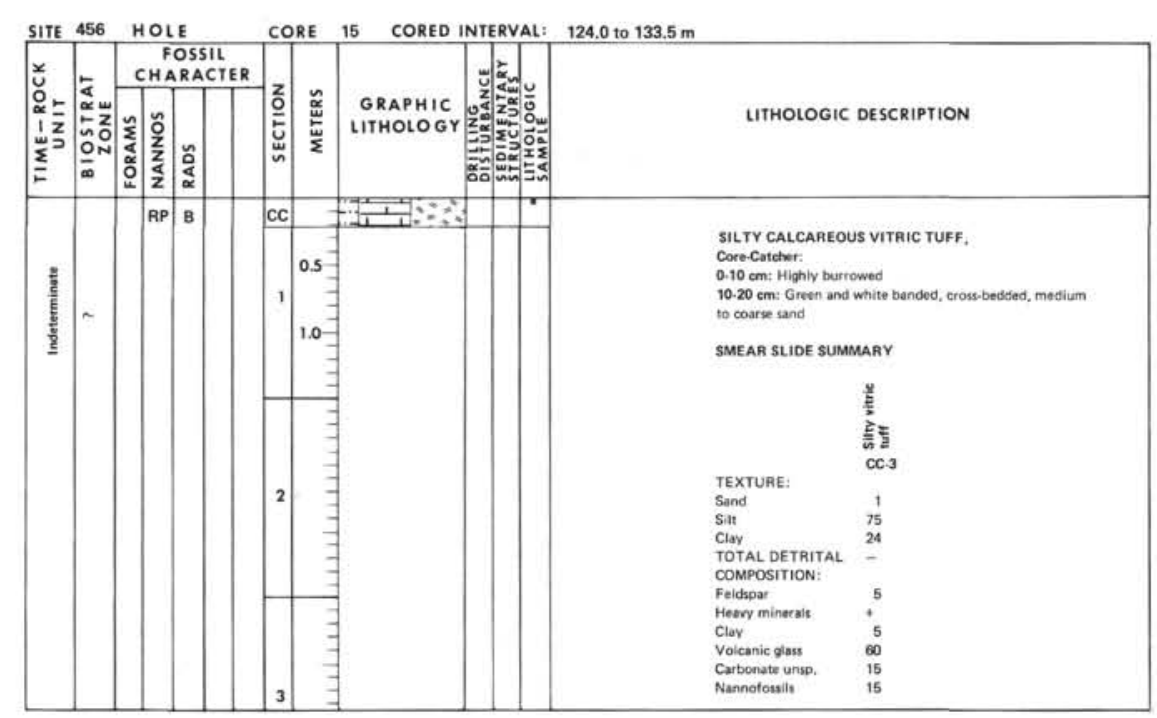




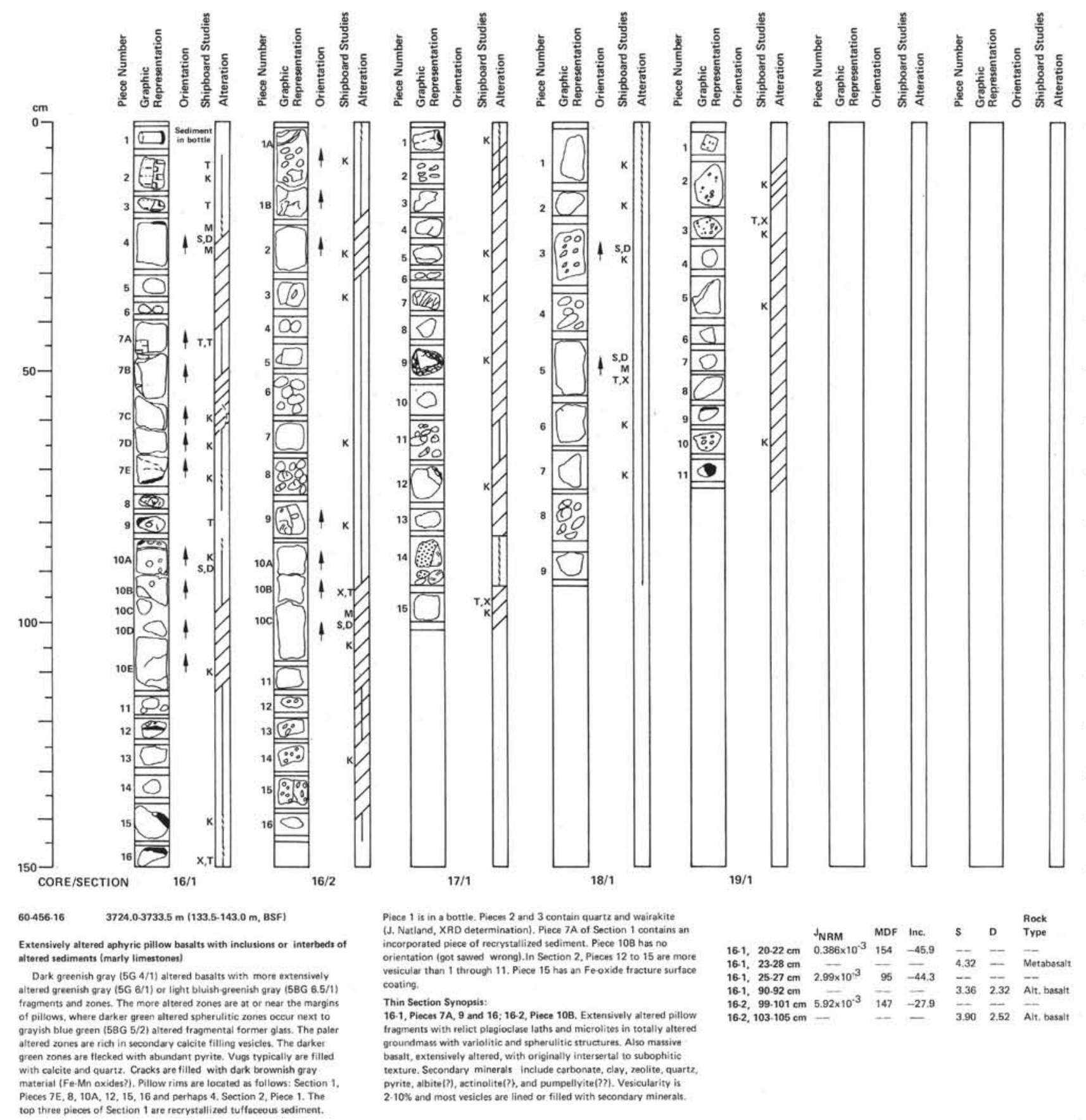

60.458-17 $3733.5 .3743 .0 \mathrm{~m}(143.0 .152 .5 \mathrm{~m}$, BSF $)$

Extensively altered aphyric pillow basalts and minot Fo-Mn (?) sedimens: 1.9, and 12 hove dark gray green altered glassy rinds. Extensiviv bleacheos zones next to rinds in this core are absent (present in Core 16). Piece 9 riddled with black Mn-material on one side. Piece 14 consists of two

types of clay-rich sediment stuck togerther. One is dark gray and fairly hard. The other is softar and redder. Perthost these were hydrogenouit
Fe-Mn deposits, later altered. Carbonate is minor in vesicles in these basalts, unlike in Core 16

Thin Section Descriptio

atered pillow basalt with originally spher liticic to subophitic texture containing relict plagioclase microlites

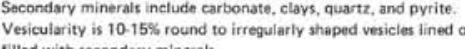

60.456. $18 \quad 3743.0-3752.0 \mathrm{~m}(152.5-161.5 \mathrm{~m}$, BSF)

Extensively altered aphyric basalt

A Asequence probabiy representing most of ona large, altered pilliow. (2.5Y 5/4), very fine-grained, and very intensely altered aphyric

basalt. The alteration is more oxidative than in Cores 16 and 17.

Piece 3 is vesicular and coorser grained than 1 or 2. Pieces 5 and 6 From 7 downward, grain size is finer, about the same as in 2 and 3. Piece 2 has sub-spheruititc plagiociases. Piece 5 is microintic. Altorat

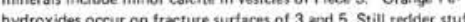
occurs on fracture surfaces of Pioce 6 , with genuine $M$ - M-oxides and

Thin Section Description:

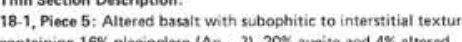

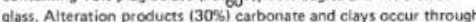
and replace glass. Vesicularity is $25-305$ irregular shaped vesicles with

JNAM MDF Inc S D Pock

$18.1,22.27 \mathrm{~cm}-1$ -

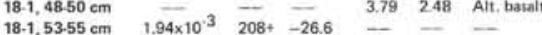

60.456.19 $3752.0 .3759 .5 \mathrm{~m}$ (1615.169.0 $\mathrm{m}$, BSF)

Moderatol

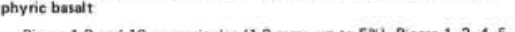

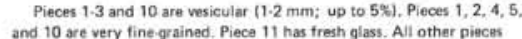

ate microlitic. Pieces $2,4,5,7$, and 8 have rare playjoclase phenocrysts

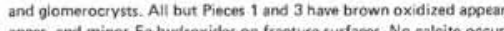

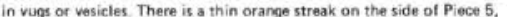
and minor palagonite replacing glass in Piece 11. There are a minimum of two cooling units rep
of these cooling units.

Thin Soction Description:
19-1, Piece 3: Aphyric basalt with intersertal texture containing 25

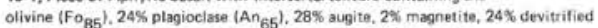
devitrieid gass. The glass is pertially altered to clays (96) and the to irreguer sopet vesicles lined with clay 


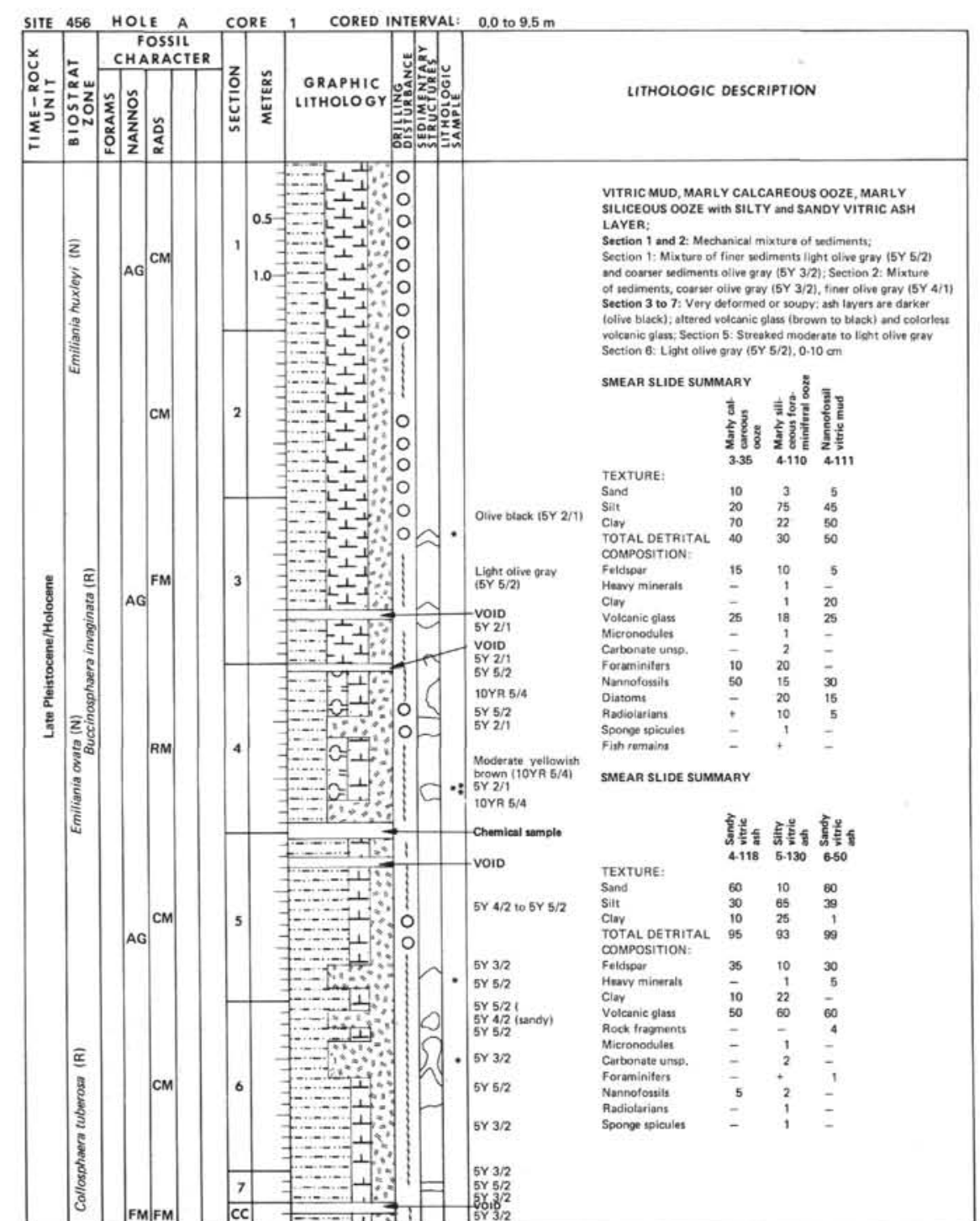

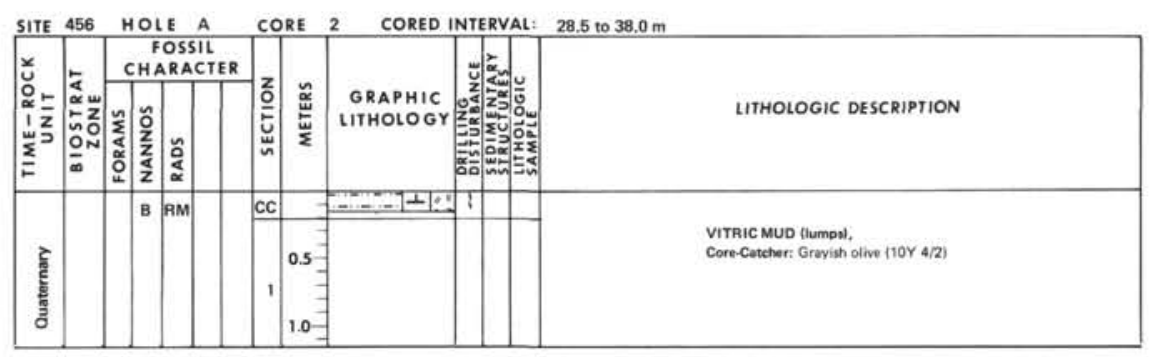

SIIE 456 HOLE A CORE 3 CORED INTERVAL: 38.0 to $47.5 \mathrm{~m}$

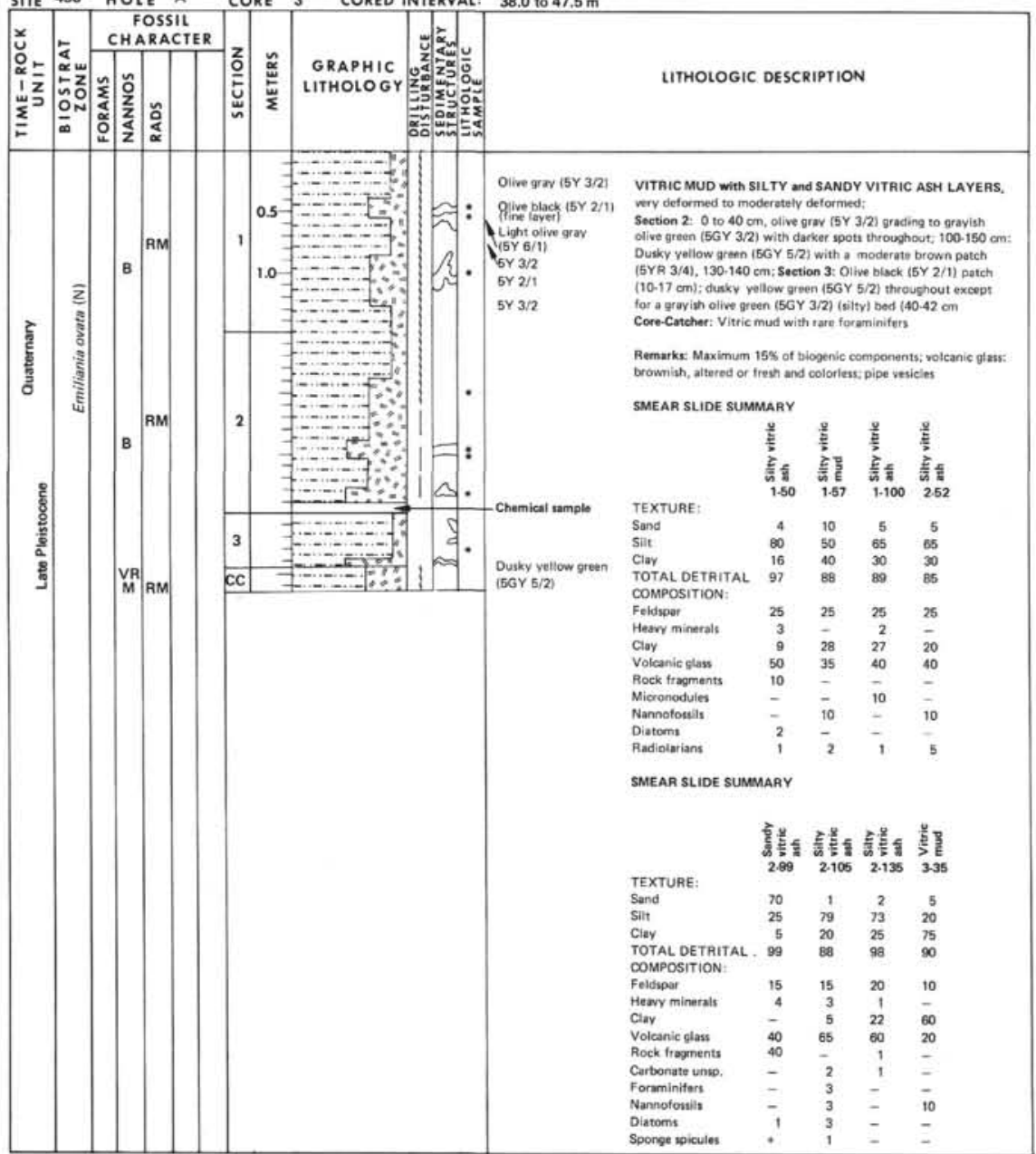




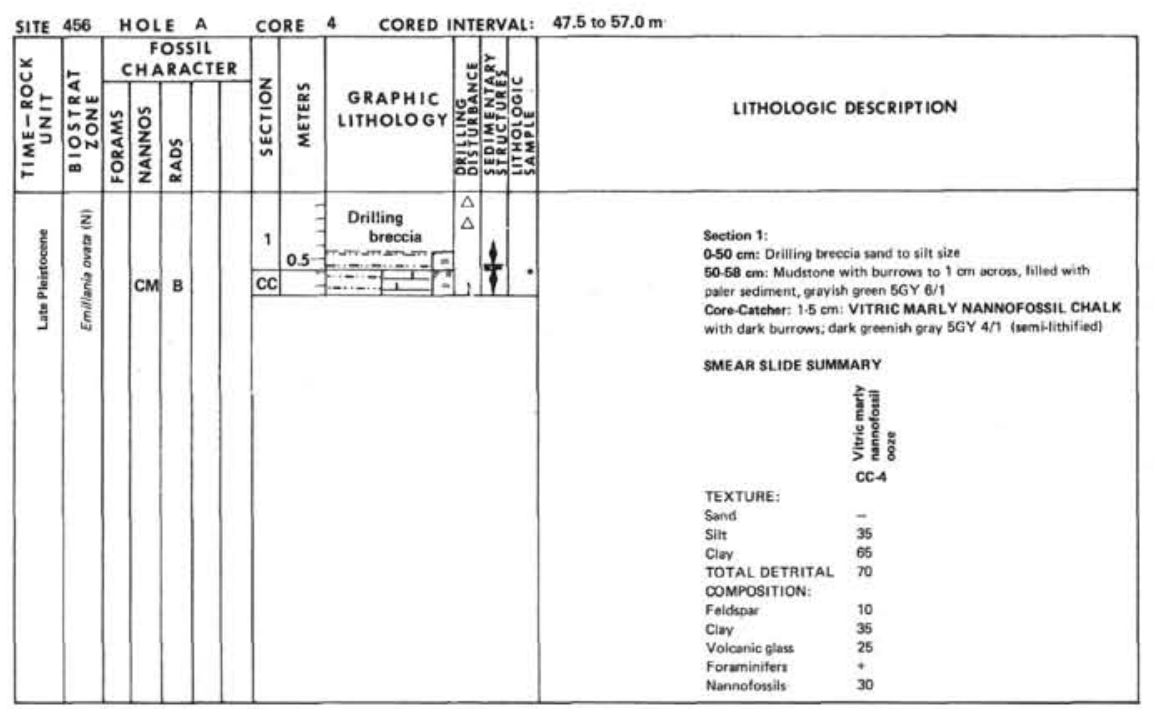

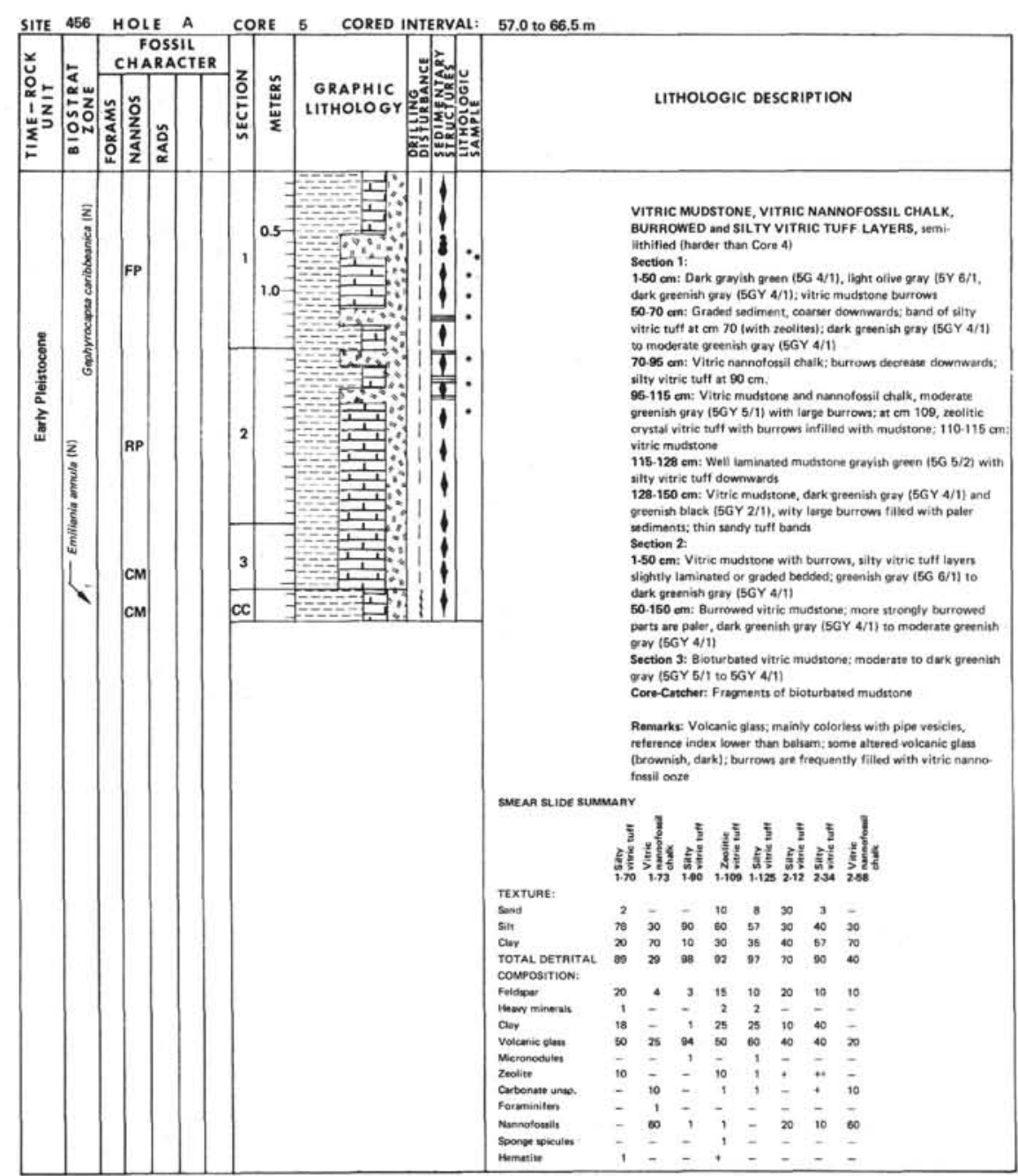




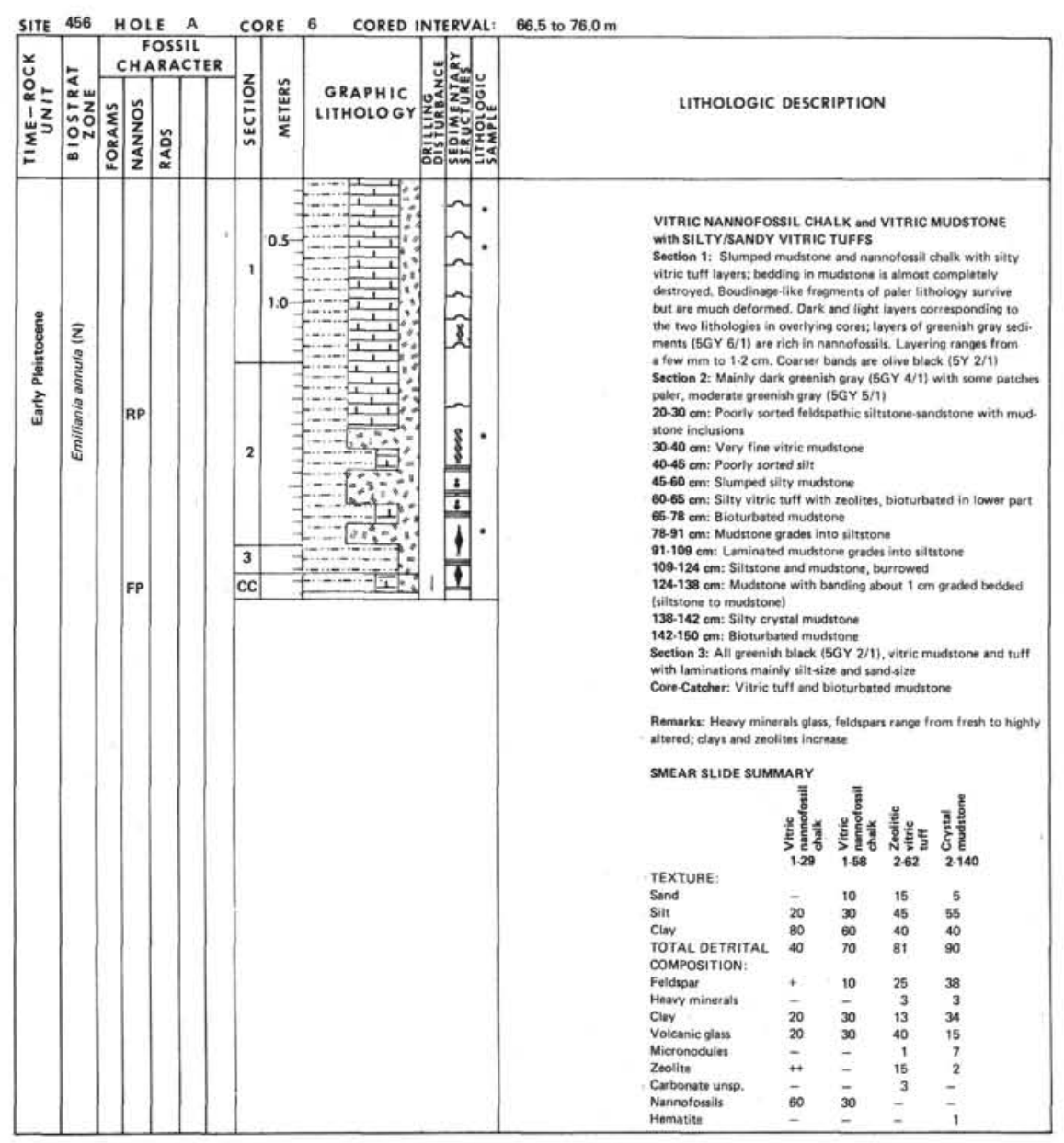

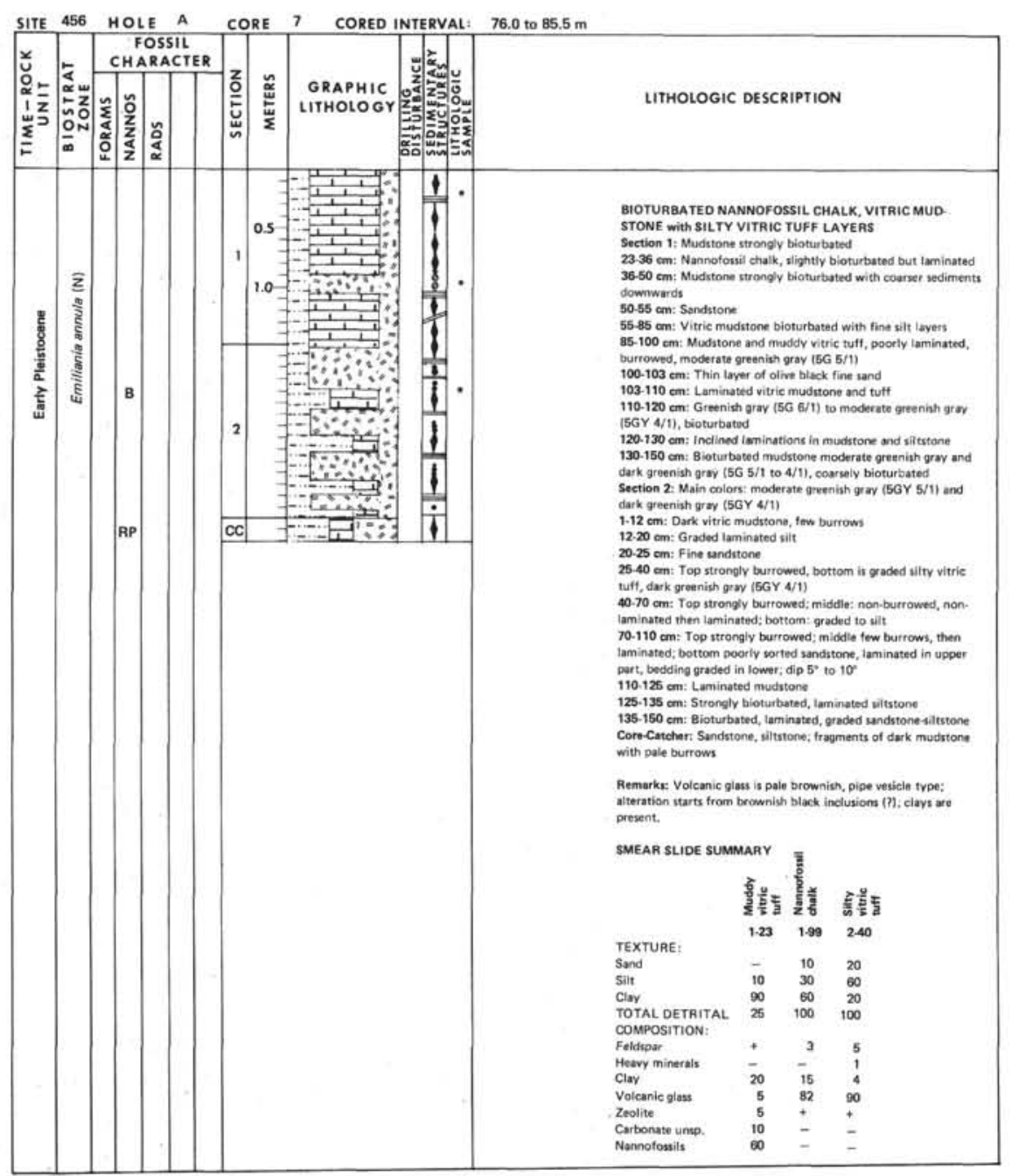




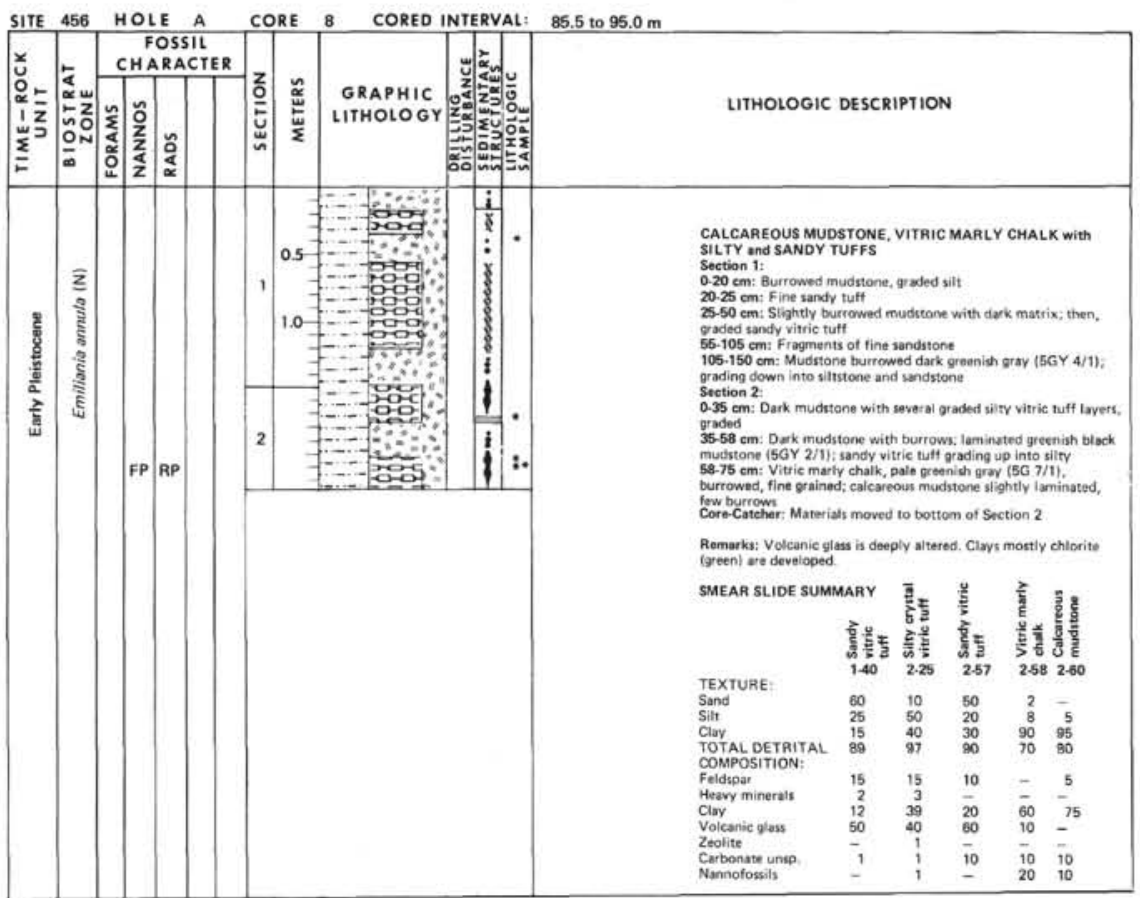

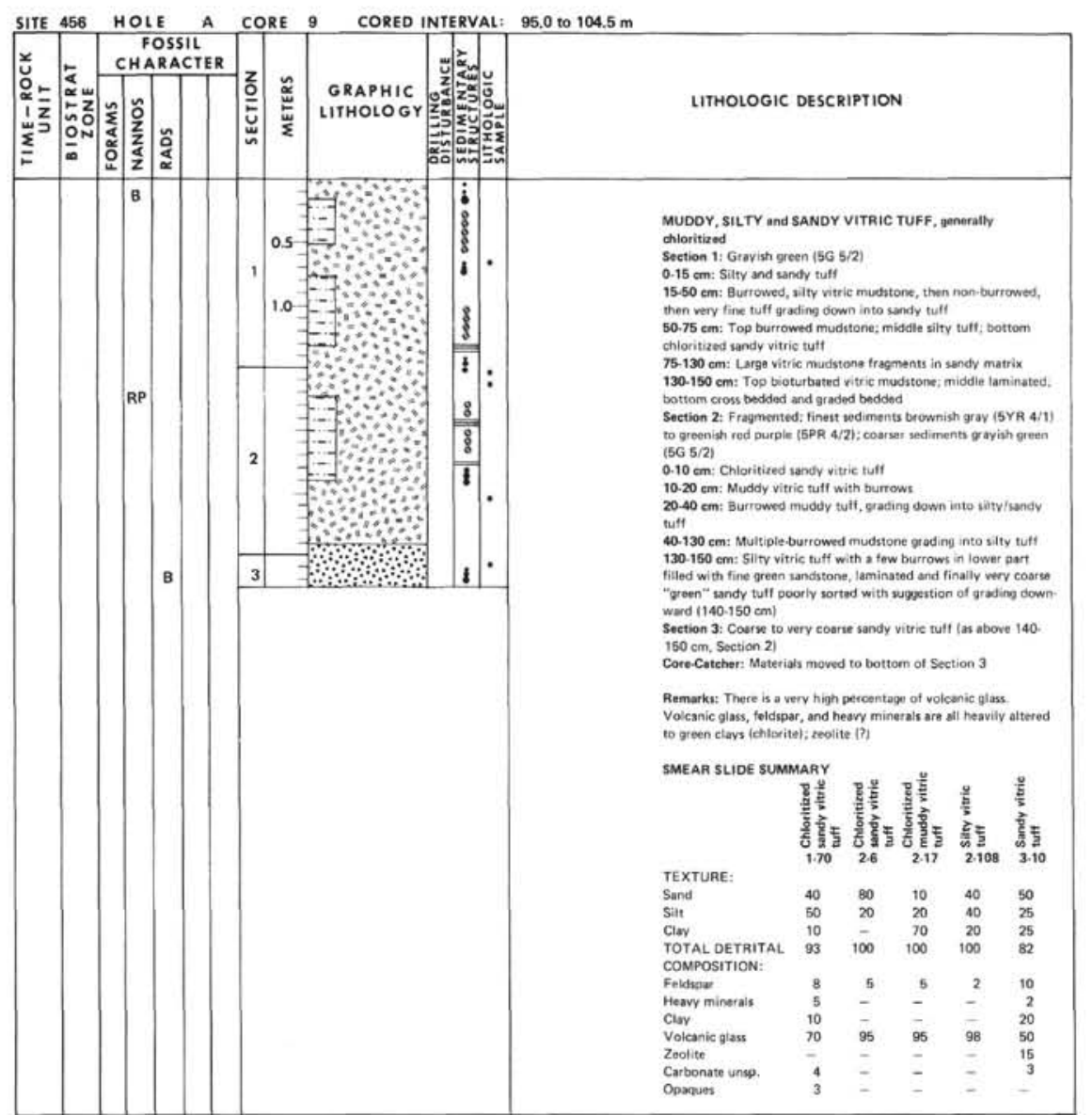




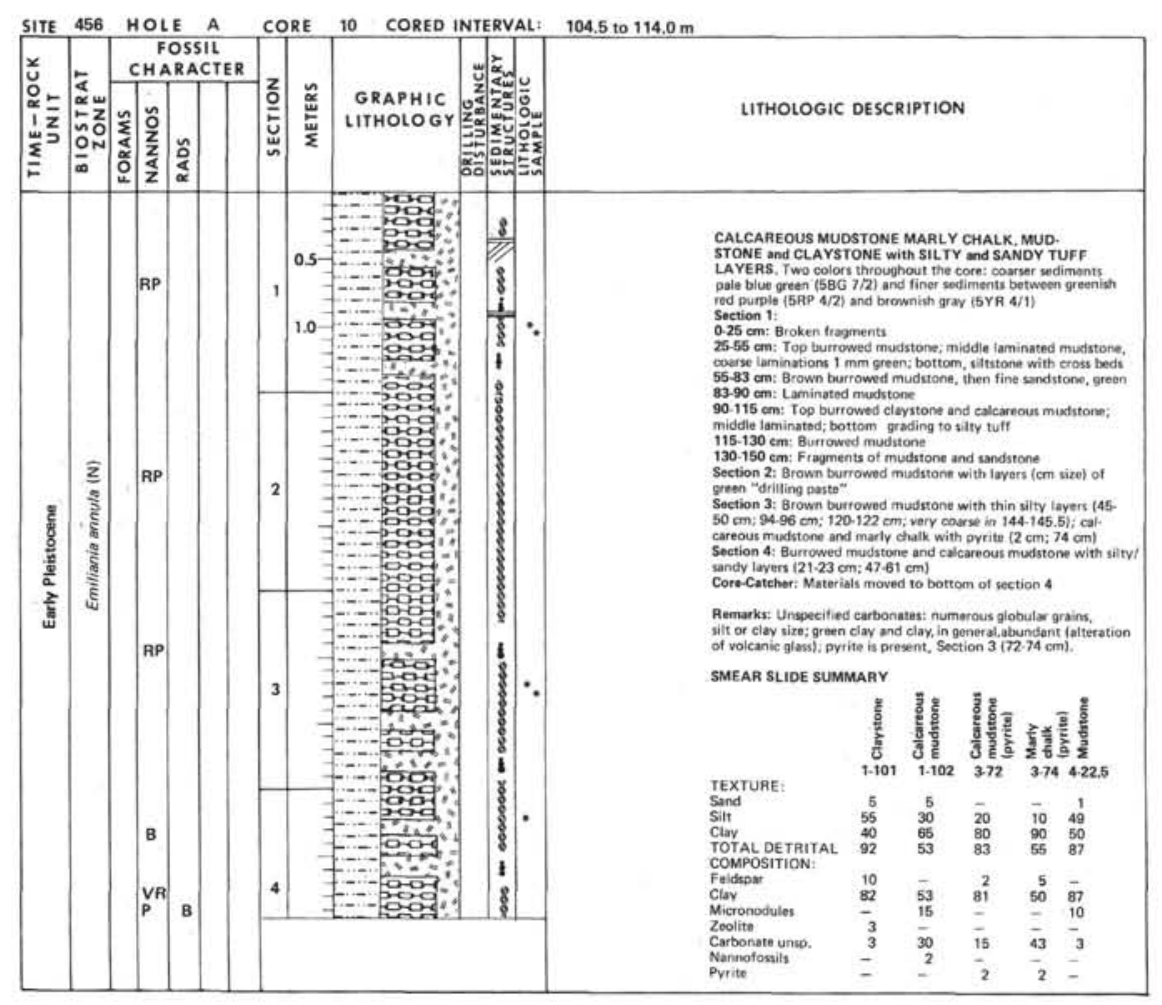

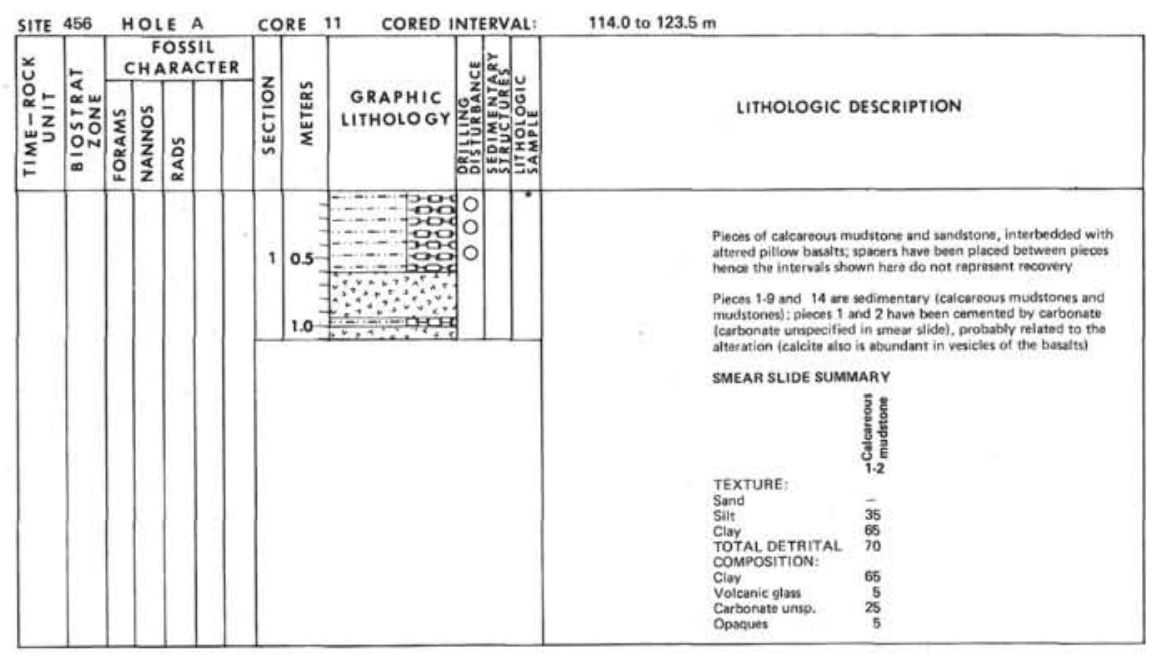




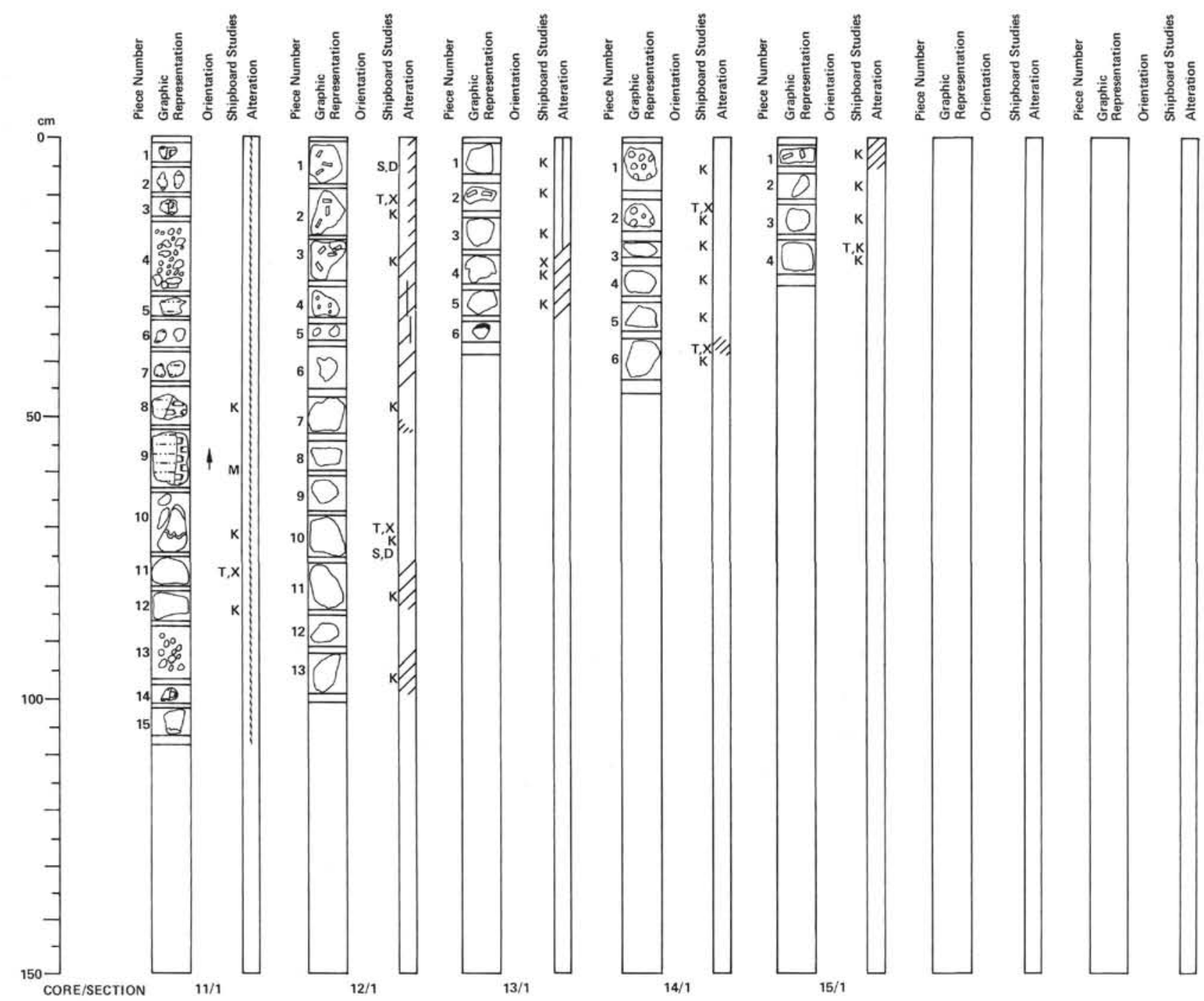

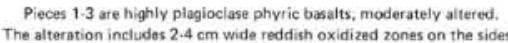
of the pieces. The rest of the core consists of vesicular $1-20 x_{0}:-1.2 \mathrm{~mm}$ aphyric bassilts, with variable alteratation. Pilice 4 has abundant veticide

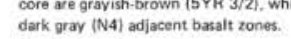

Thin Section Description

12-1, Piece 10. Altered feldspar-phyric basalt containing $20 \%$ plagioclase

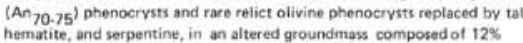
plagioclass microlites, $12 \%$ pyroxene microlites and $<1 \%$ magnetite. Ateration products composed dominantly of chlorite (55\%) with minor
2 zelite $<18$ ) occur in the groundmass and as lining or fillings of Iirregular shaped vesicles $(-2 \%)$ which are scattered throughout the rock. The

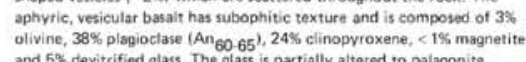

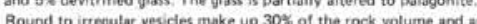

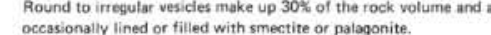

J J NRM MDF Inc. S D

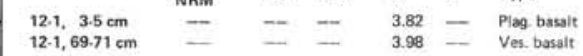
60.-456A.13 $3724.0 .3733 .5 \mathrm{~m}$ (1333.0-142.5 m, BSF Aphyic bout

Moderately to intensely sitered, but locally tresh, aphyric, vesicular Color (10YR 4/2). Piece 2 is a highty altered plagioclase phyric basalt similar to pieces 5 . of Core 12 . It probsaly fell down the hole. Vesicila in Piceces 4 and 5 are sbout 10 s of the rock and $1 \mathrm{~mm}$ diameter. Piect 6 is a small fragment of

\section{0-456A.14 $3733.5 .3743 .0 \mathrm{~m}$ (142.5.-152.0 m, BSF)}

Aphyric basalt

Pieces 1 and 2 are sightly altered, brownith biack (5YR 2/1), basalts

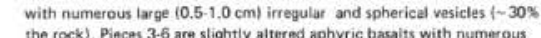
tiny spherical vesicics and a few latge $10.5 \mathrm{~cm}$ ) vesicles. Piece 6 has an atteration rind.

Thin Section SYrnopsis

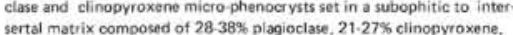

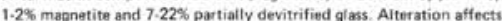
5. $15 \%$ of the rocks: secondary clays, iron oxides, and polagonite replace groundmass minerals and glass. Round to irregular vesicies some partially
filled with smectite or pal agonite comprise $7.22 \%$ of the rock wolume.

60.456A.15 $3743.0 .3750 .0 \mathrm{~m}(152.0 .159 .0 \mathrm{~m}, \mathrm{BSF})$

Plasioclase-phyric and aphyric basalt Pieces 2.4 are aphyric basalts. Pieces 2 and 3 have siny spherical
vesicies shereass 4 has moderate throughout.

\section{Fragments of mudrtone and basalt}

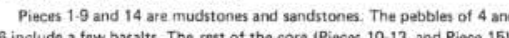
consists of highly altered light gray (N6) to light greenish-oray (5G 8/1) pillow basalt tragments lithologically identical to those described for Mole 456, Core 16 .

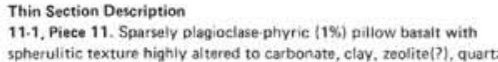
pyrite, and albite. Round to irregular vesicies $(5 \%)$ are scatterede
throughout the rock and are lined or filled with secondary minerals.

throughout the rock and are lined of filled with secondary minerals.
\[ J \text { J } \]

\begin{tabular}{lllllll}
$11-1,29.31 \mathrm{~cm}$ & J $_{\text {NRM }}$ & MDF & Inc. & S & D & Type \\
\hline & - & - & 3.46 & - & Mudstone
\end{tabular} 


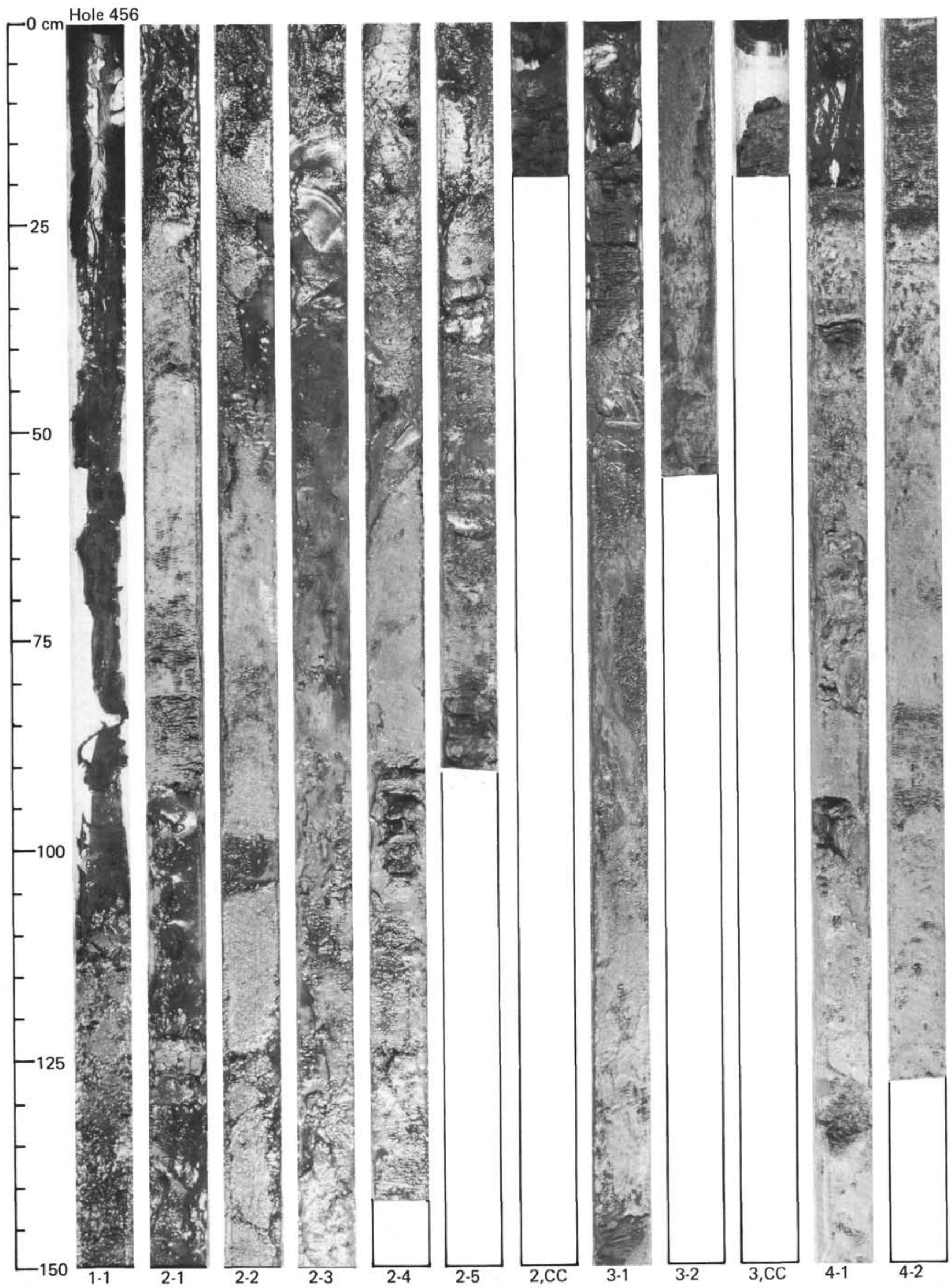




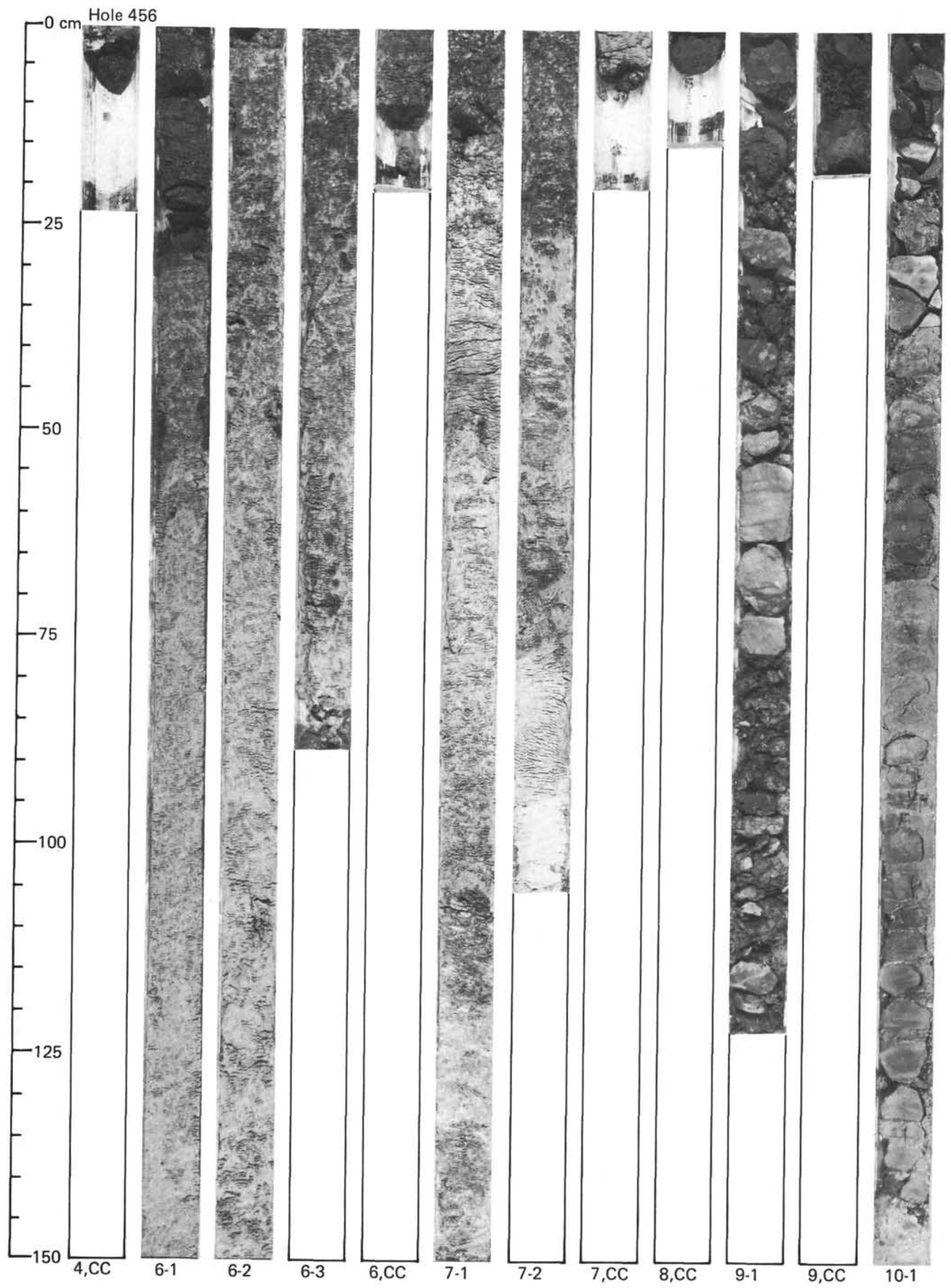




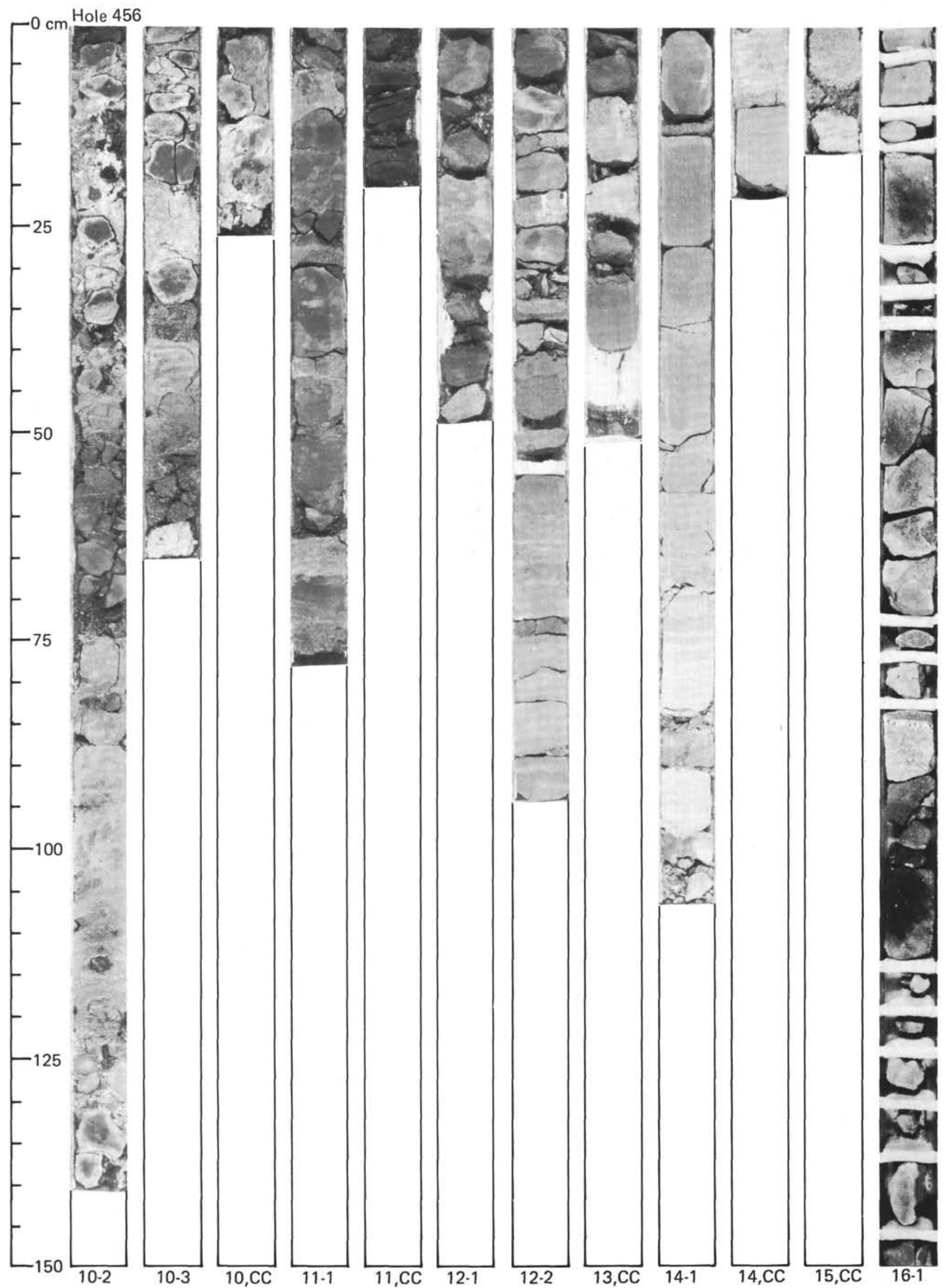




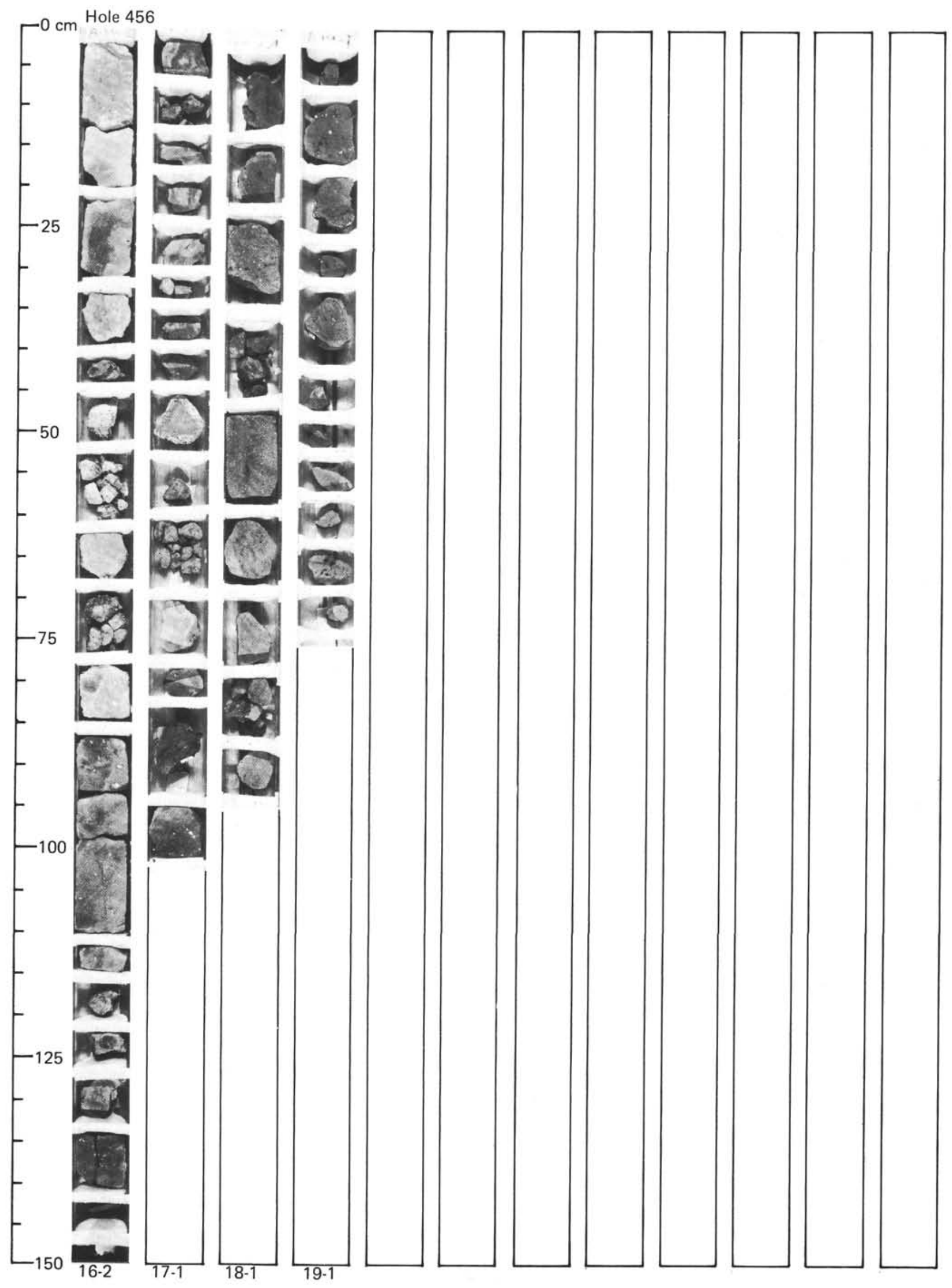




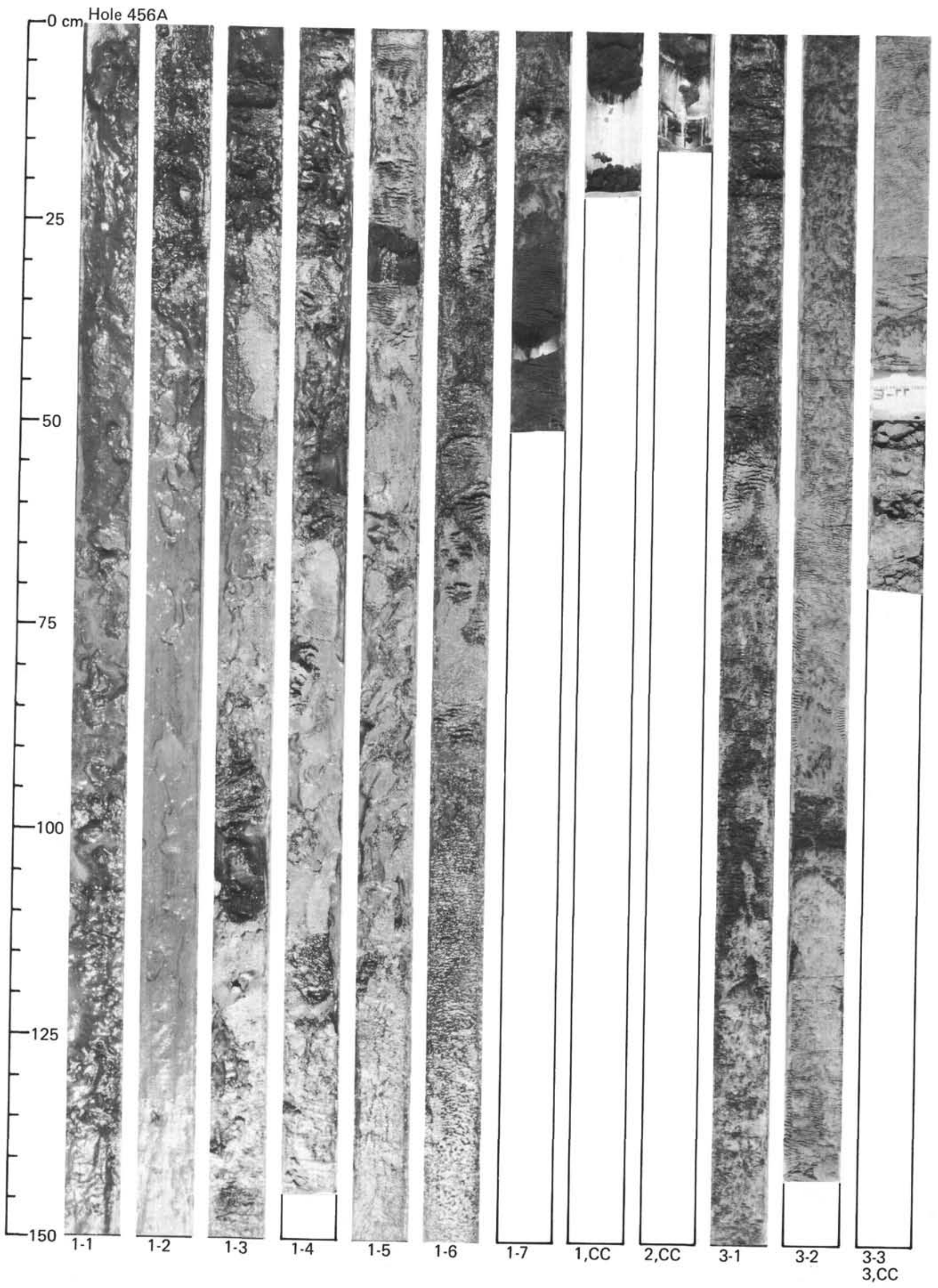




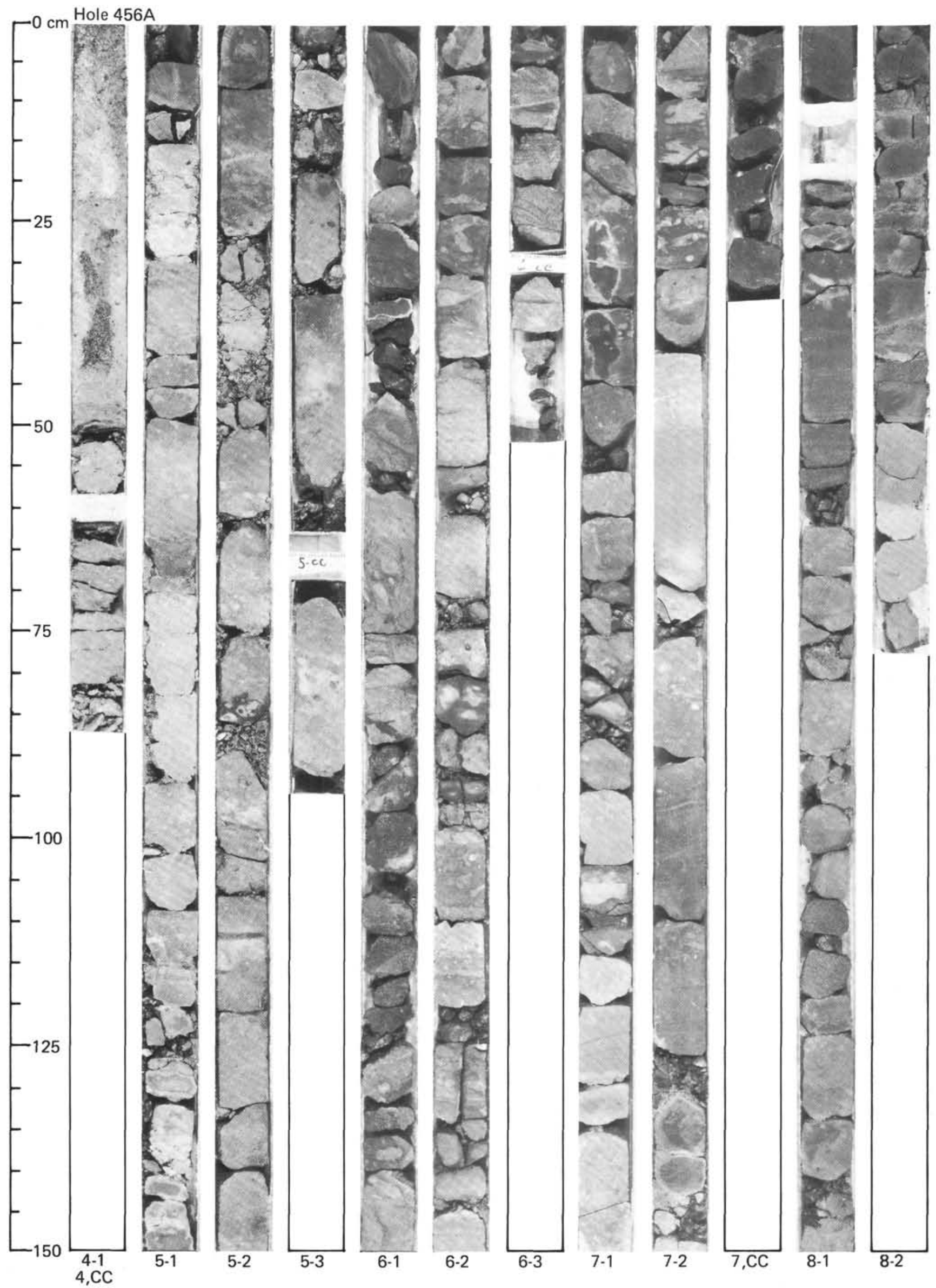




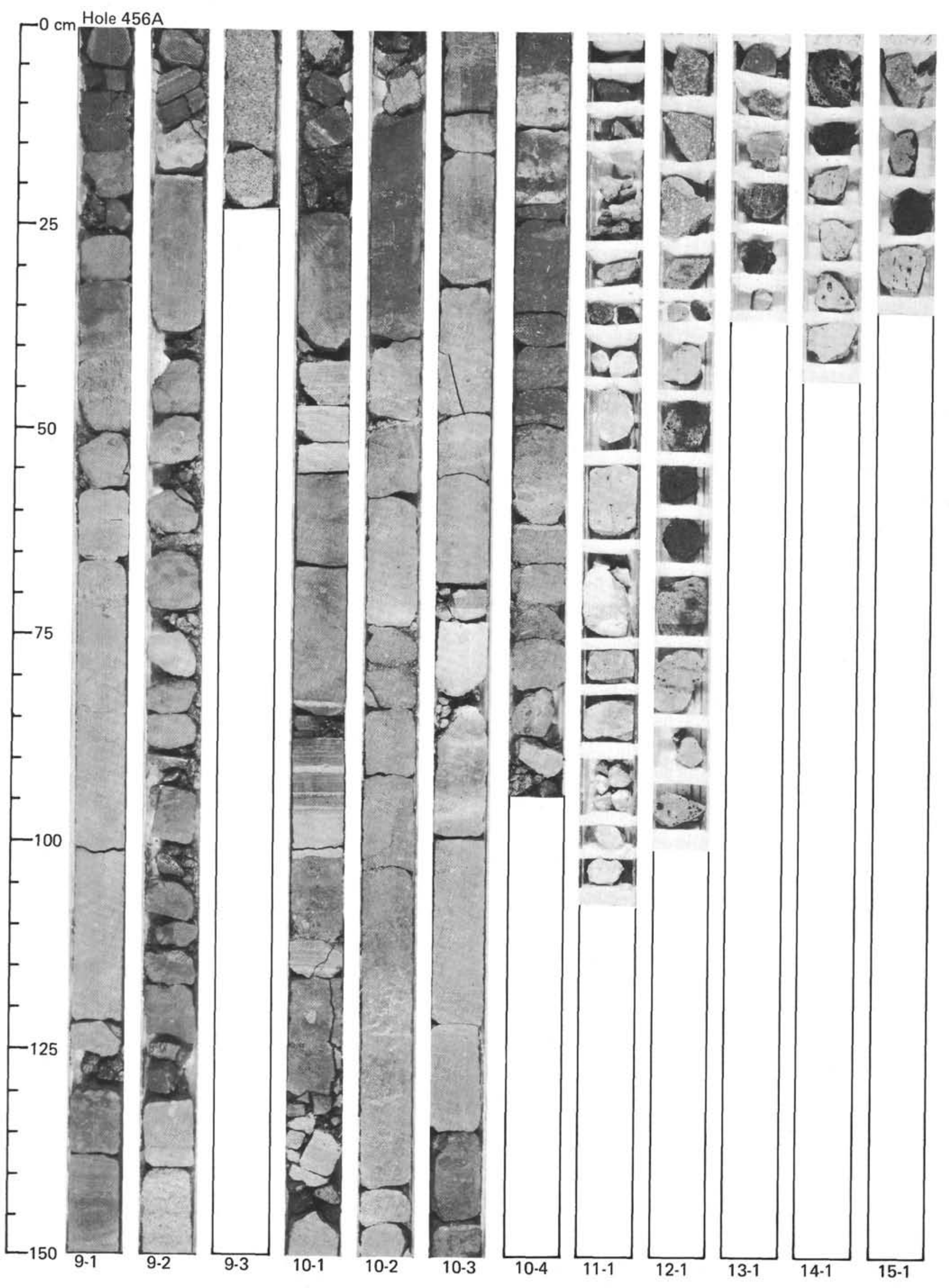

